\title{
Archaeological and Historical Investigations in the Arciniega Street Area, Downtown San Antonio Texas
}

Paul R. Katz

Follow this and additional works at: https://scholarworks.sfasu.edu/ita

Part of the American Material Culture Commons, Archaeological Anthropology Commons, Environmental Studies Commons, Other American Studies Commons, Other Arts and Humanities Commons, Other History of Art, Architecture, and Archaeology Commons, and the United States History Commons

Tell us how this article helped you.

This Article is brought to you for free and open access by the Center for Regional Heritage Research at SFA ScholarWorks. It has been accepted for inclusion in Index of Texas Archaeology: Open Access Gray Literature from the Lone Star State by an authorized editor of SFA ScholarWorks. For more information, please contact cdsscholarworks@sfasu.edu. 


\section{Archaeological and Historical Investigations in the Arciniega Street Area, Downtown San Antonio Texas}

\section{Creative Commons License}

\section{(c) (1) \&}

This work is licensed under a Creative Commons Attribution-NonCommercial 4.0 International License 


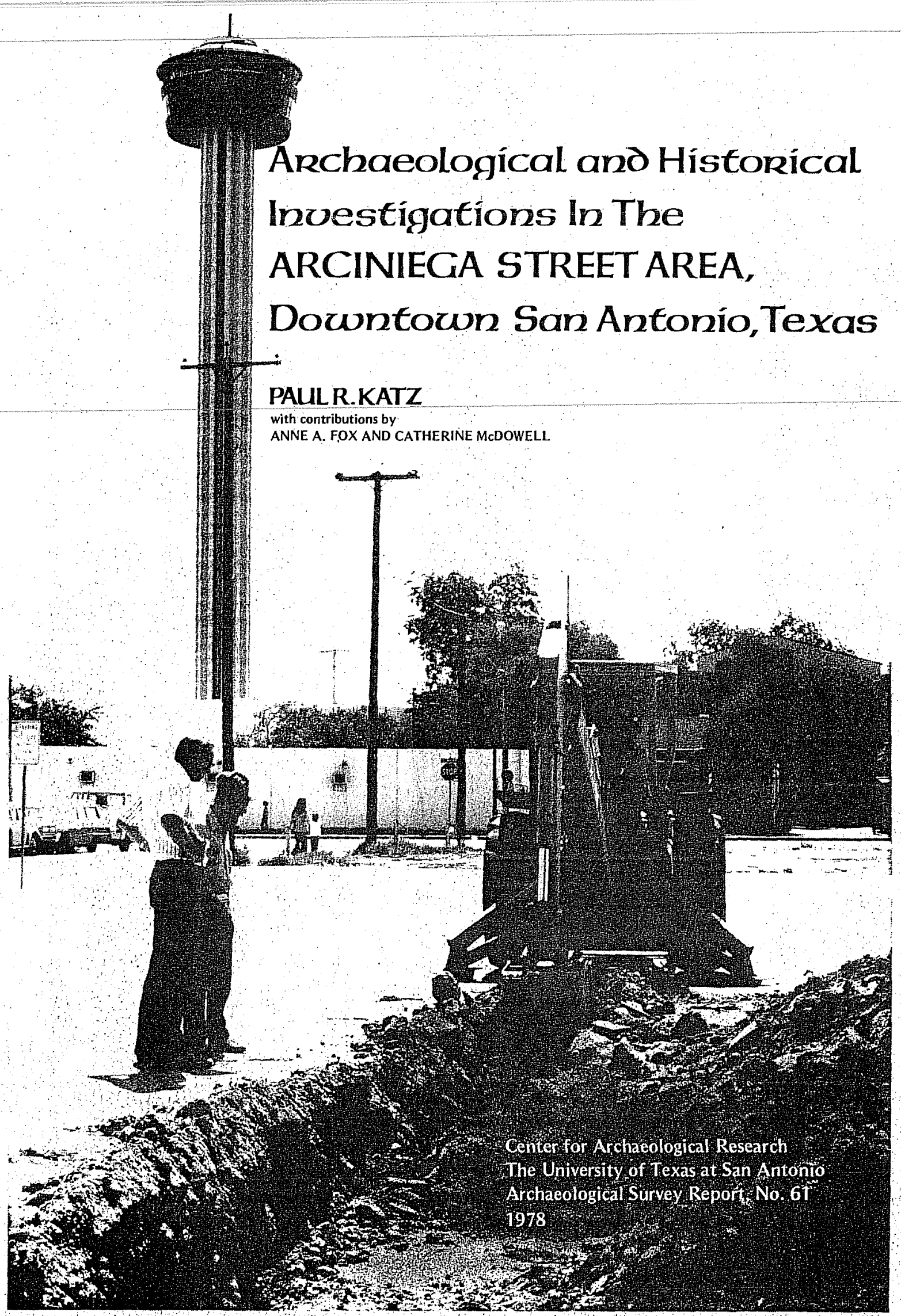




\title{
ARCHAEOLOGICAL AND HISTORICAL INVESTIGATIONS \\ IN THE ARCINIEGA STREET AREA, DOWNTOWN \\ SAN ANTONIO, TEXAS
}

\author{
Paul R. Katz
}

with contributions by

Anne A. Fox and Catherine McDowell

UTSA - Center for

Archaeological Research

Center for Archaeological Research The University of Texas at San Antonio Archaeological Survey Report, No. 61 


\section{Page}

List of figures .................. . . ij List of Tables .......................... ii Preface ..................... iv Acknowledgments .................... v Scope and Design of Project.................. 1 Historical Highlights of NCBs 901 and 155 (Catherine McDowell) . . . 12 structures .......................... 14

South Presa Street (NCB 901) ............. 14 Arciniega Street (NCB 155) .............. 17 Arciniega Street (NCB 901) .............. 20

South Alamo Street (NCB 901) .............. 30

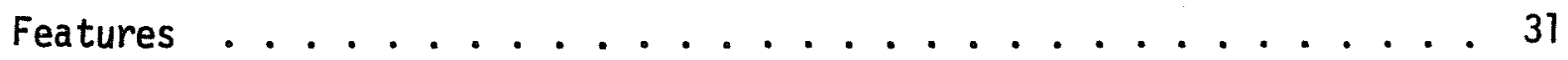

Extra-Domiciliary Features of NCB 901 ........... . . 31

Excavation of Features 4 and 4 W (Anne A. Fox) . . . . . . . 41 Summary .................. 73 References cited ................. 75 
Figure

Page

1. New City Blocks 901 and 155 in $1904 \ldots . . . . . . .22$

2. Location of Excavated Trenches ............ 4

3. Trenching NCB $901 \ldots \ldots 7$

4. Location of Excavated Foundations . . . . . . . . . . . 9

5. Portions of Foundation III and Foundation II . . . . . . 10

6. Plan of Foundation II (416-418-420 S. Presa). . . . . . . 16

7. Portions of Foundation XVI and Foundation V......... 19

8. Plan and Profiles of a Portion of Foundation $V(224-226$ Arciniega) ..................... 25

9. Foundation XII (228 Arciniega). . . . . . . . . . 27

10. Profile of a Portion of Foundation XII (228 Arciniega) . . . . . 28

11. Location of Excavated Features . . . . . . . . . . 32

12. Excavations of Feature $5 B$ and Feature $6 \ldots 33$

13. Plan and Profile of Feature 5B ............. 34

14. Profiles of Feature $6 \ldots \ldots 36$

15. Features 7 and $9 \ldots \ldots 37$

16. Profile of Feature $7 \ldots \ldots 38$

17. Feature $9 \ldots \ldots 40$

18. Excavations of Features 4 and $4 W \ldots 42$

19. Plan and Profile of Features 4 and $4 \mathrm{~W} . \ldots 43$

20. Selected Artifacts from Features 4 and 4W: Ceramic Sherds ... 51

21. Selected Artifacts from Features 4 and 4W: Restored Ceramics ................. 53

22. Selected Artifacts from Features 4 and 4W: Restored

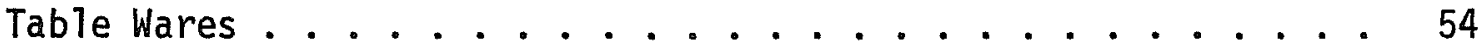

23. Selected Artifacts from Features 4 and 4W: Restored Utility Wares ................ 56 
24. Selected Artifacts from Features 4 and 4W: Porcelain . . . . . 57

25. Selected Artifacts from Features 4 and 4W: Glass Table Ware . . 58

26. Sèlected Artifacts from Features 4 and 4W: Glass Containers .. 60

27. Selected Artifacts from Features 4 and 4W: Glass Containers . . 61

28. Selected Artifacts from Features 4 and $4 \mathrm{~W}$ : 0intment and Ink Bottles.................. 63

29. Selected Artifacts from Features 4 and 4W: Medicine Bottles .. 64

30. Selected Artifacts from Features 4 and $4 W$ : Medicine Bottles .. 65

31. Selected Artifacts from Features 4 and 4W: San Antonio Drug Store Bottles................. 66

32. Selected Artifacts from Features 4 and 4W: Lighting Fixtures .. 68

33. Selected Artifacts from Features 4 and 4W: Lighting Fixtures . 69

34. Selected Artifacts from Features 4 and 4W: Personal Items. . . 70

35. Selected Artifacts from Features 4 and 4W: Personal Items. . . 72

\section{LIST OF TABLES}

Table

1. Types of Artifacts Recovered From Features 4 and $4 \mathrm{~W} . . . . . .45$

2. Datable Bottles from Features 4 and $4 W \ldots 48$

3. Faunal Remains from Features 4 and $4 W \ldots 49$ 


\section{PREFACE}

Early in 1976 the City of San Antonio Department of Planning and Community Development requested that the Center for Archaeological Research, The University of Texas at San Antonio, consider undertaking archaeological and historical investigations in the Arciniega Street area of downtown San Antonio. Sale of City-owner property--including all of New City Block (NCB) 901 and portions of NCB 155--was pending, and the Planning Department was desirous of assessing the nature and degree of cultural resources prior to completing the transaction. The proposed construction of a multi-story luxury hotel on the property would require subsurface archaeological excavations, and the property's inclusion in the La Villita Historic District suggested the advisability of extensive historical research as well.

The Center for Archaeological Research's proposal to conduct the necessary investigations was submitted to the Planning Department on February 24, 1976. On April 1 following, City Council passed Ordinance No. 46482, authorizing the funding for the Arciniega Project; and State Antiquities Permit No. 110 was issued on April 5, clearing the way for field work to commence.

Excavations were conducted during the period from May 4 through June 7, 1976. Historical research for the project commenced one week prior to the field work, and artifactual analyses began immediately upon conclusion of the excavations. Both the historical and analytical aspects of the project encountered unforeseen difficulties, in the form of complex and voluminous data; both aspects are still in process to some degree, two and one-half years after the field work terminated! Extensions for submission of the final report were granted by both the City Planning Department and by the State Antiquities Committee, extensions which were necessary and greatly appreciated.

Project Archaeologist for the Arciniega Project was Dr. Paul R. Katz, the author of this report. Assistant Field Supervisors were Center Research Associates Anne A. Fox, who excavated Features 4 and $4 W$ and authored that particular section of this report, and Susanna R. Katz, who excavated Feature 9 and assisted in the Feature 4/4W and other feature and trench investigations. Curation and analys is of excavated materials were supervised by Anne A. Fox and Shirley Van der Veer. other Center staff members and volunteers who participated in the field work and laboratory portions of the project are acknowledged by name elsewhere in this report. Historical research was supervised by Catherine McDowe11, Director of the DRT Texas History Research Library, ably assisted by Gloria Cadena and Maria Watson.

Maps, plans and profiles drawn in the field by the supervising staff, assisted by Elizabeth Cantu Frkuska, were drafted for publication either by Augustine Frkuska or by the UTSA Office of Instructional Services. The author was aided in the preparation of this report by Jack Eaton, Assistant Director of the Center and by Karen Moloney, Center secretary. The entire Arciniega Project was under the supervision of Dr. Thomas R. Hester, Director of the UTSA Center for Archaeological Research. 


\section{ACKNOWLEDGMENTS}

I wish to express my sincerest gratitude to those persons 1 isted below, all of whom provided invaluable assistance toward the successful conclusion of this project:

Field Work

Jeff Birnberg

John Blakeman

Laura Brusenhan*

Anne A. Fox

Elizabeth Cantu Frkuska*

Mary Beth Galvan-Moore*

Kevin Healy

Susanna Katz

Wanda Kaufman

Roberta McGregor*

George Meyer*

Tim Newberg

Dena Stoner*

David Swinehart

Shirley Van der Veer*

Ruth Wells*

Backhoe Operation

Roy Davenport

Daniel Mendoza

Artifact Curation and Analys is

Anne A. Fox

Lynn Highley

Shirley Van der Veer
Historical Research

Gloria Cadena

Catherine McDowel1

Maria Watson

Faunal Analysis

Billy Davidson

Report Figures

Augustine Frkuska

Office of Instructional

Services, UTSA

Manuscript Preparation

Jack Eaton

Carol Graves

Karen Moloney

Project Coordination

Christopher Carson, of Ford, Powell \& Carson, Architects

Dr. Thomas R. Hester, Director, Center for Archaeological Research

Jose Lucero and Martha Buchanan, of the Plaza Nacional Group Howard Peak, of the City of San Antonio Planning Department

* volunteer 
Boundary and Nature of the Project Area

That portion of downtown San Antonio of specific concern to the Arciniega Project included all of New City Block (NCB) 901 and the southern portion of NCB 155, the latter situated immediately north of NCB 901 (Fig. 1). Both blocks are bounded on the west by South Presa Street and on the east by South Alamo Street. Arciniega Street runs east-west between the two blocks. The present southern boundary of NCB 901 is Durango Boulevard, but this is a recent phenomenon constructed in conjunction with Hemisfair in the late 1960s. The former southern boundary was Martinez Street, which still exists on the south side of Durango for this one block. The construction of Durango removed the two southwestern and three southeastern lots of NCB 901 (Fig. 1). The area investigated by the project comprised four and one-half (4.491) acres. Both blocks are subsumed with in the 11 block, 15-acre La Villita Historic District, listed on the National Register of Historic Places inventory (Be11, Hume and Williamson 1971).

It should be noted that two other systems for designating the area in question are currentiy in effect. Because archaeological investigations were to be conducted on these two blocks, site numbers were assigned by the Texas Archeological Research Laboratory in Austin: 41 BX 303 for NCB 901 and 41 BX 304 for NCB 155. In addition, purchase of the property under consideration by the Urban Renewal. Agency in the late 1960s resulted in a consolidation and renumbering of former lots in NCB 155 and an entirely new block number for NCB 901. At the time of this project, NCB 901 was designated NCB 13816, with only a single lot (Lot 1 ). NCB 155 retained the same block number, with the following lot number changes: the entire southeastern quadrant, formerly Lots $1,2,3$ and 26, is now Lot 30; and the southwestern corner, formerly Lots 23 and 24, is now Lot 31. Lot 25 of NCB 155, located between the current Lots 30 and 31 , was and still is owned by St. John's Lutheran Church and was not affected by the lot renumbering; this particular lot shows as 211 and 213 Arciniega on the 1904 Sanborn map (Fig. 1). For reasons of both clarity and convenience, the current lot numbers ( 30 and 31 ) will be employed when discussing NCB 155; the designation "NCB 901 " will be retained when discussing this particular block, and house numbers will be used rather than lot numbers when a specific portion of this block is considered. Even here there may be some confusion, as the NCB 901 house numbers shown on the 1904 Sanborn map (Fig. 1) do not always correspond to the numbers in effect at the time of the project; these latter numbers will be employed in the report and discrepancies noted when pertinent to the discussion.

A11 of NCB 901 and Lots 30 and 31 of NCB 155 were owned by the City of San Antonio at the initiation of the project in 1976. The area was characterized by a variety of usages at this time, however. In 1968, Lots 30 and 31 of NCB 155 and the eastern half and southwestern corner of NCB 901 were paved with asphalt to provide additional parking for Hemisfair visitors. In 1976, Lot 30 of NCB 155 and the paved area of NCB 901 were still being used for public parking, the lots in question being leased by the City to Aliright Parking, Inc. NCB 155, Lot 31 was also still paved, but its use was limited to occasional overflow parking by patrons of St. John's Lutheran Church under a tacit agreement with the City. The western half of NCB 901, north of the paved parking 


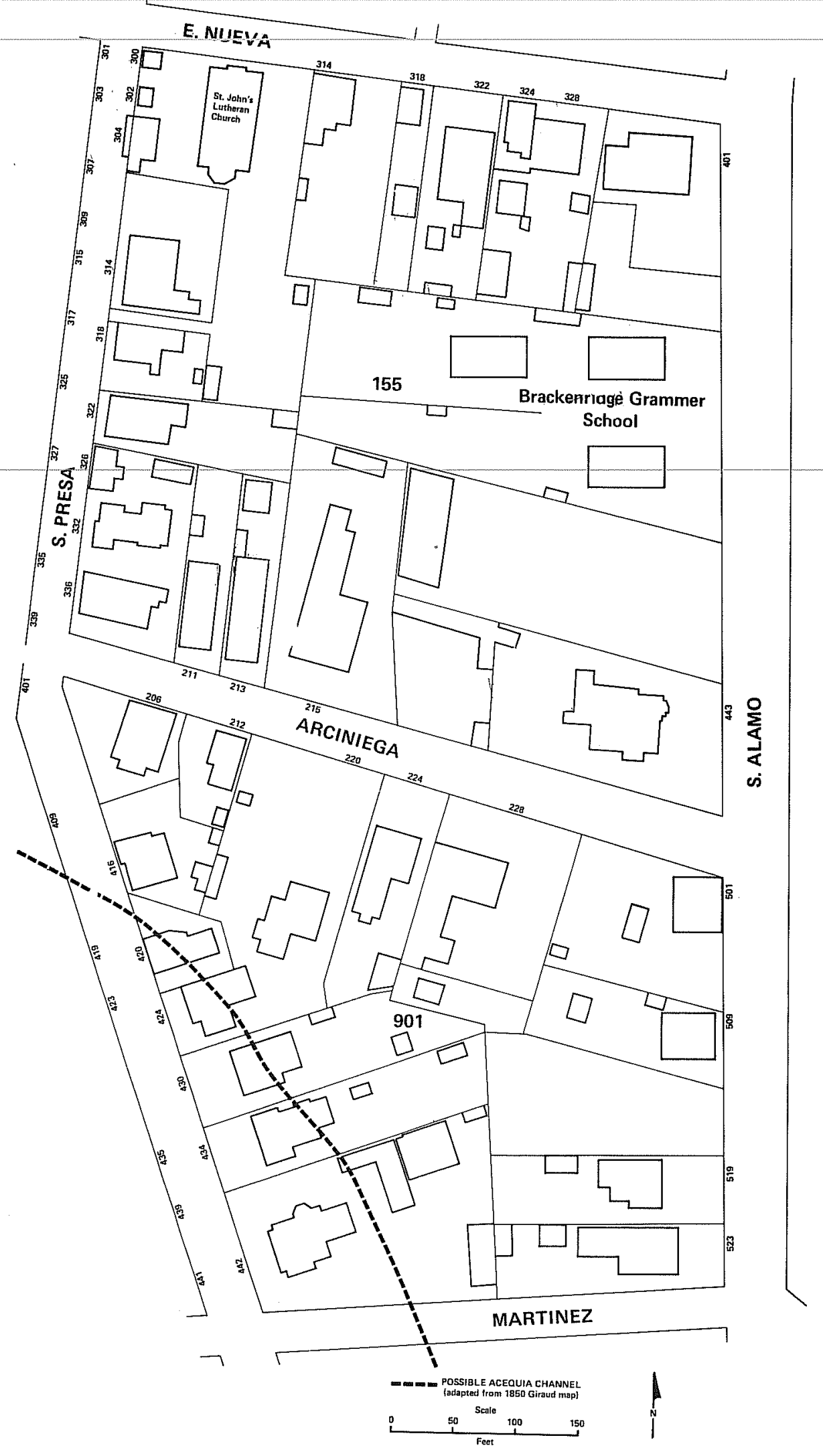

Figure i: New City Blocks 901 and 155 in 1904. Redrawn from Sanborn Insurance Maps of San Antonio, Volume 1. 
area, was in grass and was characterized by three houses left standing when the remainder of the block's structures were razed by the Urban Renewal Agency. These three structures, spared from destruction primarily because of their historical and architectural value, bear the current addresses of $422 \mathrm{~S}$. Presa (424 S. Presa in Fig. 1), 204-206 Arciniega and 220 Arciniega. A fourth house, 232 Arciniega (not shown in Fig. 1), was left standing after the Hemisfairrelated razing activity on NCB 901, but was demolished immediately prior to the beginning of archaeological investigations in 1976.

The nature of those portions of downtown San Antonio bounding the project area on the east and north should be mentioned, as it has a direct bearing on the raison d'etre of the project. Eastward across S. Alamo is the southwestern portion of Hemisfair Plaza, extending from the E. Nueva Street gate south to the Festival Ballet at the corner of S. Alamo and Durango. Several blocks to the north, across E. Nueva, is the La Villita Historic District and the Riverwalk. Immediateiy north of Lot 30 on NCB 155 is the old German-English School, designated a State Historical Landmark. Shown as the "Brackenridge Grammar School" in Fig. 1, this structure occupies Lots 4 and 5 and is utilized as offices by the City's Planning Department. Finally, in the northwest corner of NCB 155, Lot 30 (formerly behind 215 Arciniega and on Lot 26) is the ruin of a stable which was the scene of previous archaeological investigations in the late 1960s. This ruin was thought to be the last vestige of a Spanish Colonial cuartel, or barracks, presumably destroyed prior to the seige of the Alamo in 1836.

\section{Impact of the Hotel}

Characteristics of the project area created an ideal situation for the construction of a luxury hotel on the property. It is located within short walking distance of the Riverwalk, Hemisfair Plaza, La Villita and the Convention Center; it was practically unstructured and offered adequate space for both the hotel's physical plant and associated parking; and it had a single owner, the City of San Antonio.

The Plaza Nacional Group entered into negotiations with the City to purchase the property and engaged the firm of Ford, Powell and Carson as planners and architects. Preliminary plans were made available to the project staff at the initiation of field work in 1976, forming the basis of the orientation of the resulting excavations. The extent to which the final plans differ from the preliminary plans is not known to the writer. It can be stated parenthetically that periodic observation of the hotel's construction has led to the opinion that subsurface excavation was deeper and more extensive than the preliminary plans indicated would be the case. In any event, the following discussions of hotel configuration and facilities, of excavation orientation, and of the outline of the hotel's periphery shown on accompanying figures are all predicated on the nature of the preliminary plans as they existed in the spring of 1976.

The multi-story guest wings, restaurants, shops and a swimming pool were to be constructed on the eastern half of NCB 901 (al1 parking lot at the time), entering the western half of this block primarily in the northern portion fronting Arciniega, as far as the former location of 212 Arciniega (Fig. 2). The three structures left standing on the western half of NCB 901 would be renovated and 


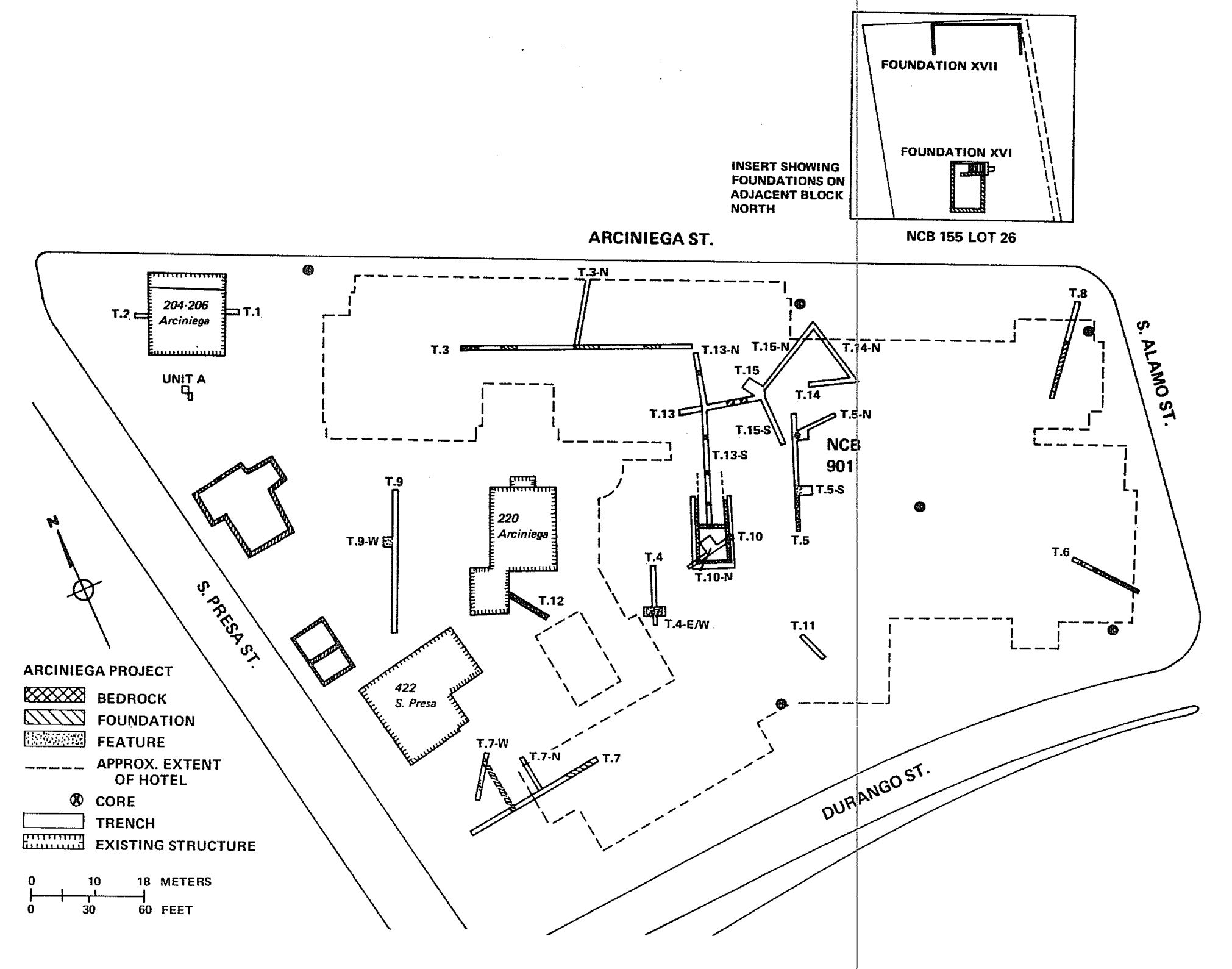

Figure 2. Location of Excavated Trenches. 
utilized for restaurants and meeting faciitities. Lots 30 and $3 i$ of NCB 155 would remain paved and continue to serve their present function, but parking would be limited to guests of the hotel and patrons of its associated facilities. An unspecified number of tennis courts were also planned for NCB 155, preliminarily located on Lot 30. The intention was to close Arciniega Street to through traffic, it now being an integral part of the hotel area. A walkway was also planned from the hotel property on NCB 155 toward E. Nueva and La Villita, its route taking it past the ruined wall at the rear of former Lot 26 which had been postulated as a Spanish Colonial cuartel (Fig. 2, insert).

Apart from the general disturbance of the property during construction of the hotel, subsurface excavation would be required on NCB 901 for support piers, foundation and a limited basement area on the Durango side. Utility hookups for both the hotel and the renovated buildings would necessitate trenching over the entire block. Given that the property in question belonged to the City of San Antonio, all prehistoric and historic manifestations associated with the property, both known and as yet undocumented, were automatically designated as State Archaeological Landmarks under Section 6 of the Texas Antiquities code then in effect. The probability that most, if not all, of the subsurface landmarks would be damaged or destroyed during the course of construction formed the basis of the negotiations and the resultant contract to conduct archaeological and historical investigations detailed in the preface. In addition, the listing of the three existing houses on NCB 901 on the National Register of Historic Places inventory brought certain sections of the National Historic Preservation Act of 1966 into effect.

\section{Orientation of the Investigations}

Research oriented toward a reconstruction of the occupational history of the project area was given first priority in the investigation design. It was assumed that data resulting from this research would not only be invaluable for interpretation of excavated material, but it would also lead to an increased efficiency and predictive capability during the actual field investigations.

The historical research phase of the project benefited from the fact that NCB 155 has been previously investigated in connection with the wall ruin on Lot 26. This wall had been postulated as representing the last vestiges of a Spanish Colonial structure known as the "Quartel," and both archaeological and historical investigations were conducted concerning the structure between 1965 and 1969 (Luckett n.d.; Santos 1967; Schuetz n.d.). Consequent1y, the major thrust of the current project's research was oriented toward the history of NCB 901 .

Archaeological testing was scheduled to begin several weeks after the initiation of the historical research phase, in the hope that sufficient data would be available to guide the archaeologists in better selecting specific areas to excavate. The historical phase would then continue concomitantly with the field work so that mutual exchanges of information could benefit both groups of investigators.

The archaeological testing would focus on the eastern half of NCB 901 , as this was the portion of the project area which would be subjected to the most extensive subsurface disturbance. Given that a considerable area needed to be 
investigated and that this area was covered with asphalt, it was decided that a backhoe would be needed for the preliminary excavations (Fig. 3). The preliminary architectural drawings were studied, so that the archaeological excavations could be located in the approximate area where the hotel foundations would be placed (Fig. 2). The western half of NCB 901 would experience relatively little subsurface disturbance, that being small utility trenches needed for renovation of the three existing houses. Consequently, it was decided that only small test units need be excavated in the rights-of-way of the proposed utility trenches, given that their location could be decided by that time (Fig. 2 ).

No subsurface disturbance was planned for those lots on NCB 155 involved in the hotel project; only tennis courts and possible repaving work was intended. Nevertheless, several questions remained as a result of the investigations into the Quartel's location, one of which being the fact of its very existence. It was agreed that the archaeologists would devote part of the field time to further investigating the area around the wall ruing the historical researchers would likewise attempt to augment the data already available on this structure and attempt to resolve the still-unanswered questions regarding the enigmatic Quartel and its presumed Tocation in the project area.

Six weeks were allotted for the historical research and four for the archaeological field work; the latter would begin after the former had progressed for two weeks and both were to terminate at the same time. The historical investigations would be coordinated by Catherine McDowell of the Daughters of the Republic of Texas Library at the Alamo, assisted primarily by Gloria Cadena of the Center for Archaeological Research staff. Archaeological field work would be directed by Paul Katz of the Center staff, to be assisted by Susanna Katz and Anne A. Fox, also Center staff members. The field crew would be composed of laborers hired specifically for this project and augmented as necessary by volunteers from the UTSA student body and the Southern Texas Archaeological Association. Overall coordination for the UTSA portion of the project was provided by $\mathrm{Dr}$. Thomas Hester, Director of the Center for Archaeological Research; most of the bureaucratic operations were ably handled by Kathy McCauley, Dr. Hester's administrative assistant. City-UTSA-Plaza Nacional Group coordination was conducted by Howard Peak of the Planning Department staff.

Field work commenced on May 4 and terminated five weeks later on June 7 . The additional week was necessary due to frequent and excessive rain during the field portion of the project, and even with this extension the scheduled 20 field days were not actually worked. The historical research phase began only one week prior to the commencement of field activities; and due to a degree of quantity and conflict pertaining to the uncovered documentation which was impossible to foresee, it is still in progress.

\section{Highlights of the Excavations}

Fifteen numbered trenches of various lengths were excavated on NCB 901, one on NCB 155, although when cross-trenches, expended portions of trenches and isolated squares are counted, the total number of excavated archaeological units is 31 (Fig. 2). All but three of these units were initially excavated by backhoe, then subsequently cleaned out by hand. The walls and floors of every unit were drawn to scale on gridded paper, as well as extensively photographed. 


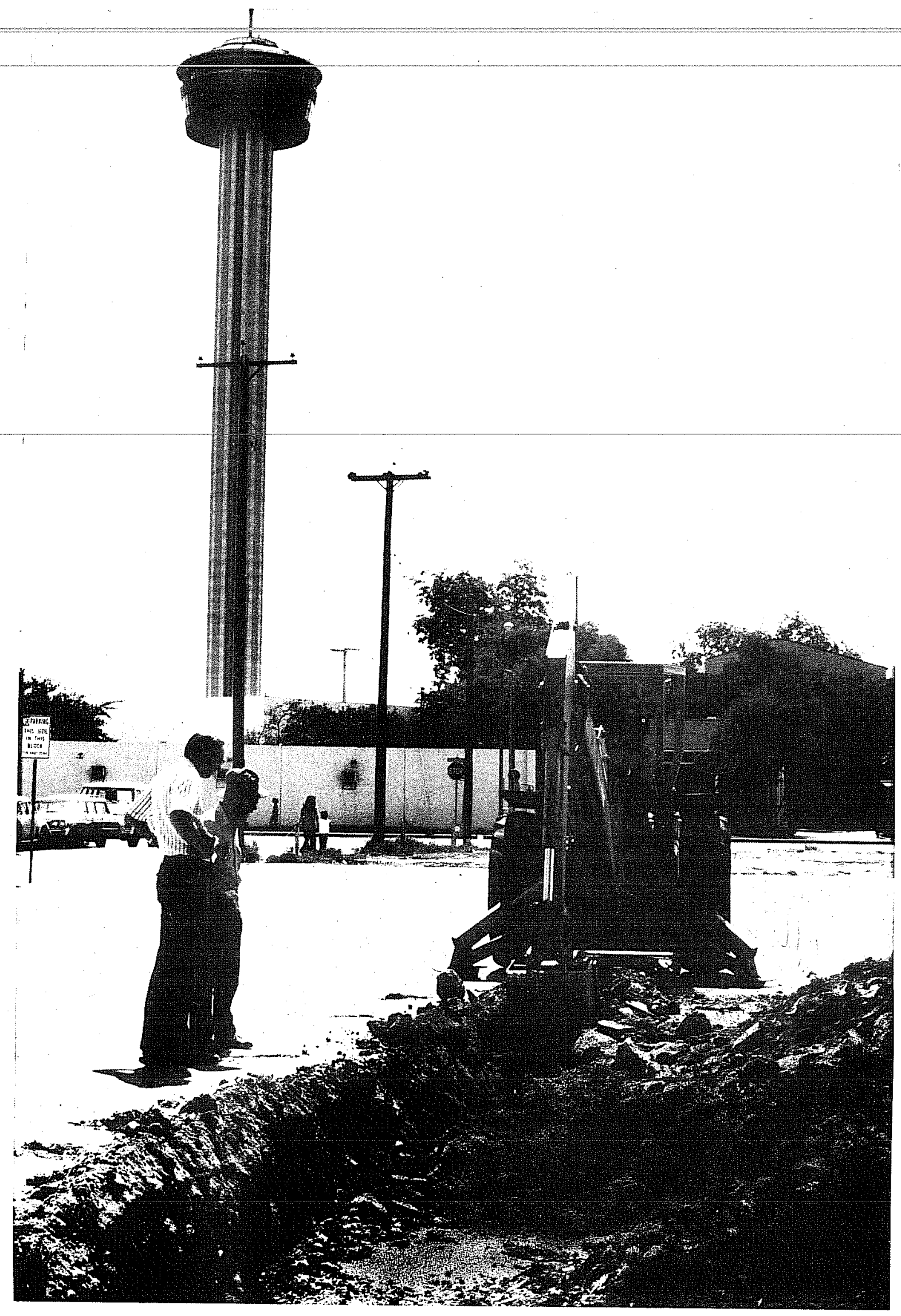

Figure 3. Trenching NCB 901. The parking lot (east portion of NCB 901), showing backhoe activity in progress, looking east toward Hemisfair Plaza. 
The initial placement of trenches followed the testing design presented above, with in the proposed limits of the hotel foundation and across rights-of-way of proposed subsurface utility lines in the vicinity of the existing houses (Fig. 2). Where a portion of a previous foundation or a previously unsuspected cultural feature was uncovered by a first-order trench, additional units were excavated to expose more of the foundation or feature in order to facilitate identification and recording (Fig. 4 ).

As data from the historical research became available, several trenches were cut to search specifically for the remains of foundations or features considered important for either the occupational historical reconstruction or for the recovery of period artifacts needed for interpretation of previously uncovered foundations and features.

Two foundations of houses fronting South Presa Street (412 and 416-418) were completely exposed and drawn (Fig. 4). This was accomplished partiy to provide data for the occupational history and partly to provide useful and necessary work while trenches in other portions of the block were drying out after a rain. One complete room at the rear of the house formerly at 228 Arciniega Street was entirely exposed; research had suggested that this portion of the house might be the oldest structure on the block, and excavation was deemed necessary to observe the construction of the foundation and to collect any associated artifactual material. During the course of excavations, portions of the foundations of every other structure documented to have been constructed prior to 1900 were located and recorded. Small trenches were dug perpendicular to two of the three houses still standing (204-206 and 220 Arciniega Street) to record their construction as well (Fig. 4).

Three cultural features were located and completely excavated (Fig. 11): an unlined latrine pit (Feature 9) between the houses formerly located at 412 South Presa and 200 Arciniega; an unlined kitchen trash pit (Feature 5B) east of the house formerly located at 228 Arciniega; and a rock- and,brick-lined, rectangular cistern (Features 4 and $4 \mathrm{~W}$ ) located behind the former 224 Arciniega. A tremendous amount of artifactual material was recovered from these features, including over 100 bottles of various shapes and sizes, broken crockery exhibiting numerous patterns and methods of decoration, and quantities of mammal and fish bone. As very few artifacts were associated with any of the foundations that were exposed, the material from these three features will provide the primary data for both chronological and behavioral reconstuction. 0ther non-architectural features which were documented include portions of three unl ined ditches (Features $5 A, 6$ and 7), which may represent acequia lateral channels, and one additional unlined pit (Feature 12) of unspecified function.

The engineering firm of Raba and Associates drilled a series of seven cores at those places where the main foundation pylons of the hotel were scheduled for placement (Figs. 2,4,11). No deeply buried cultural material was observed as a result of this coring.

The stratigraphy encountered during excavation was consistent, if not uniform, over the entire two blocks, except where intrusive cultural features were present. Figure 5,a presents a picture of this stratigraphy: asphalt over a yellow gravel asphalt base, below which was a layer of rubble from the demolition of the various structures on the blocks; below the rubble was either 


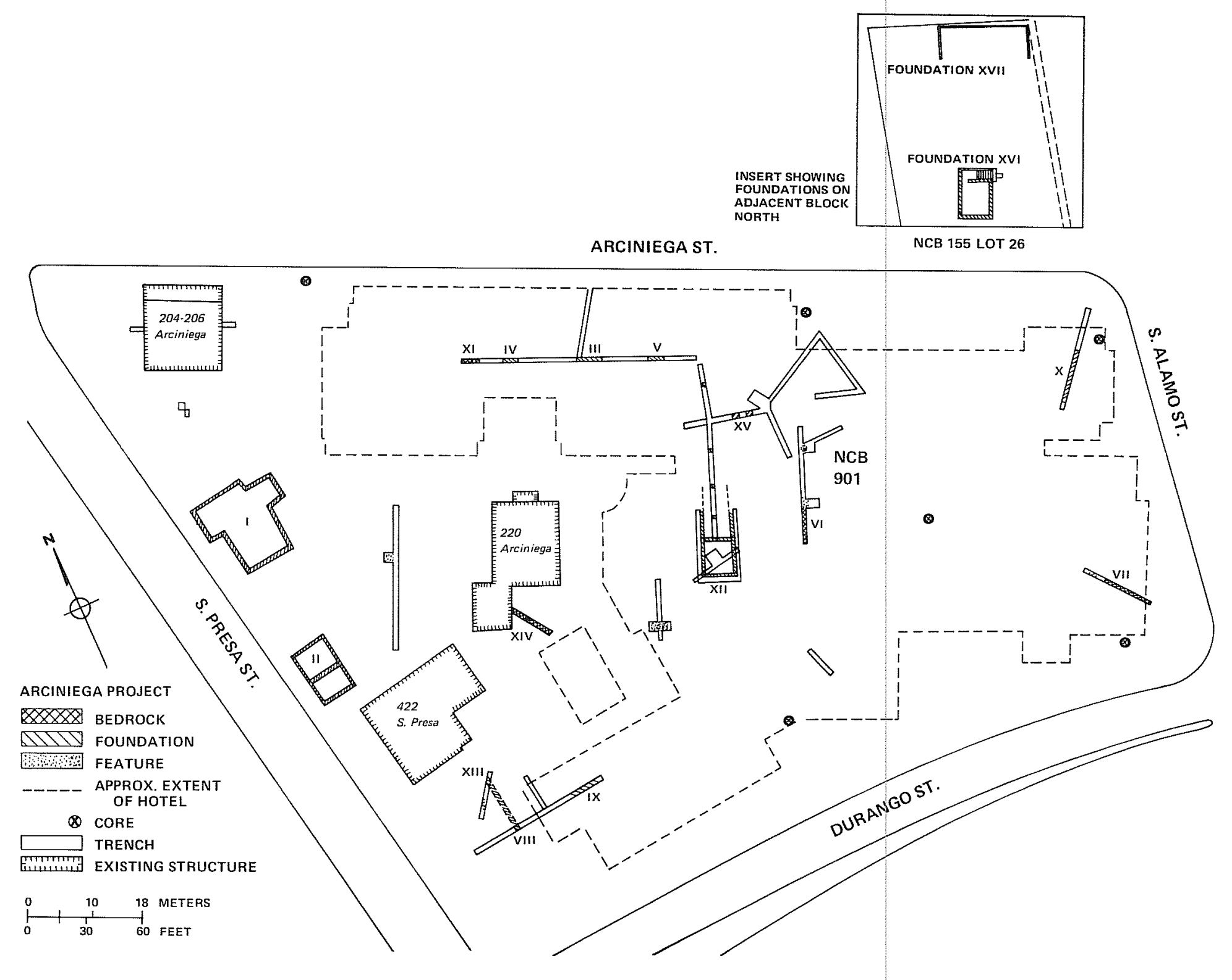

Figure 4. Location of Excavated Foundations. 


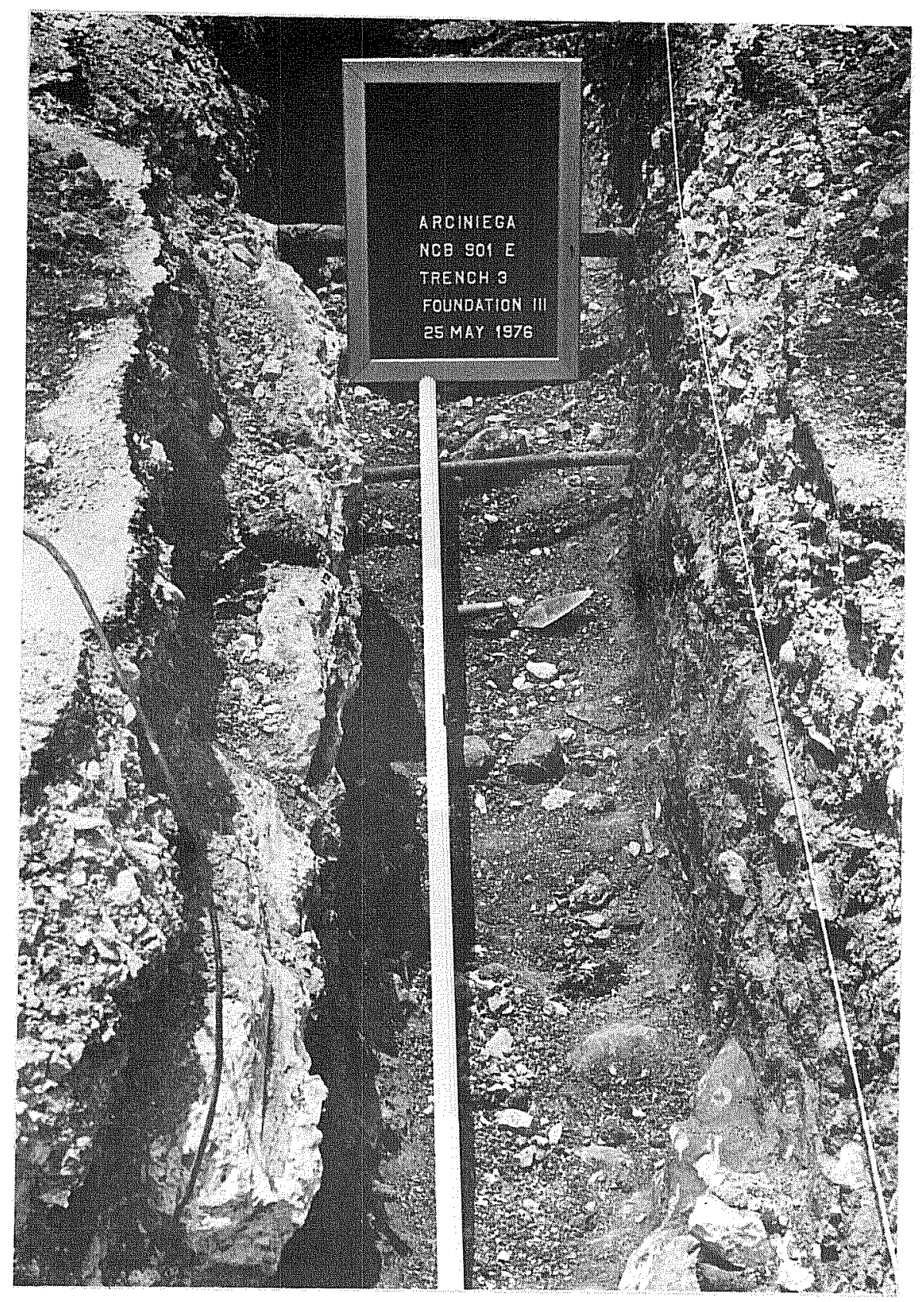

a.

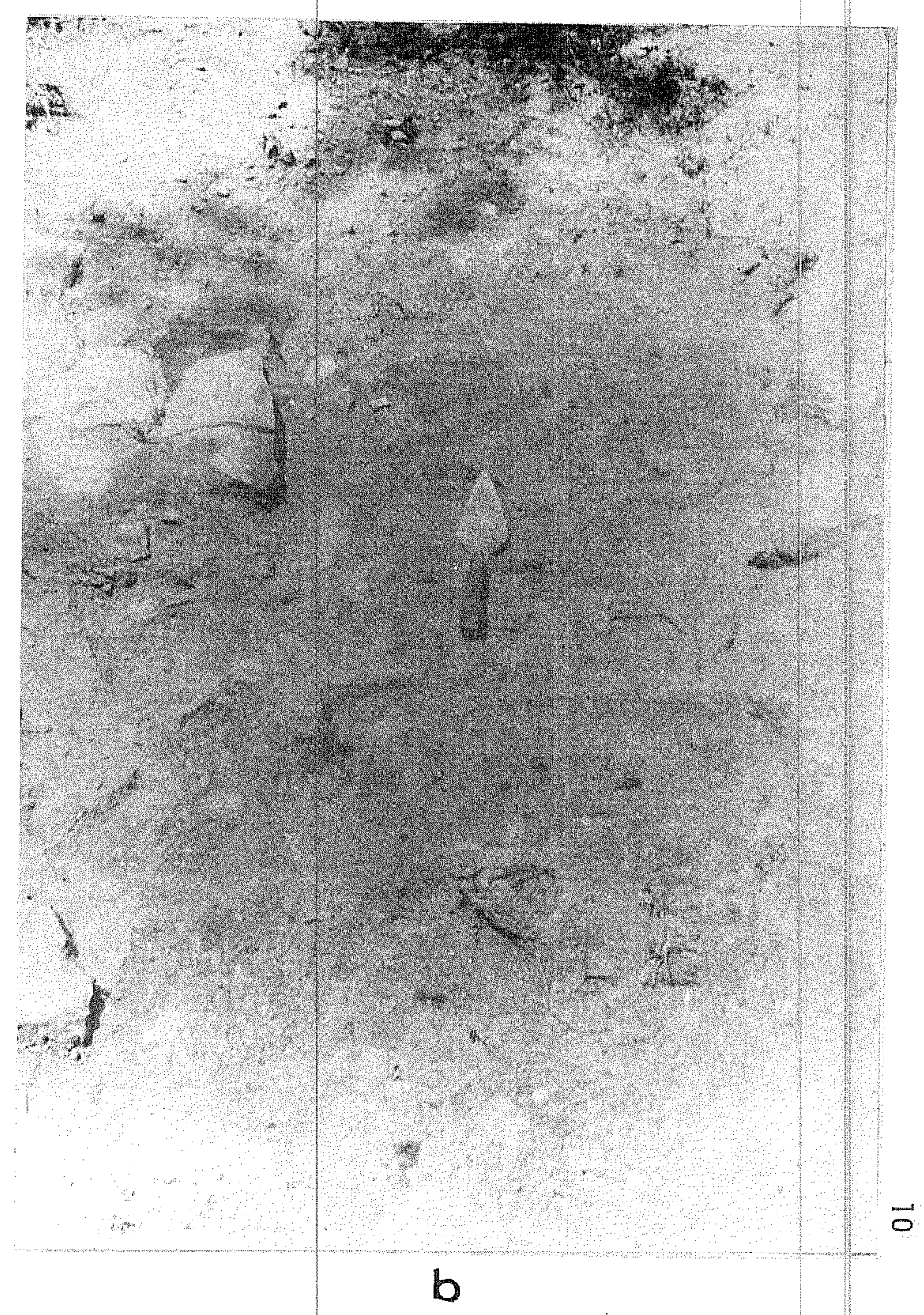

$\vec{o}$

Figure 5, Portions of Foundation III and Foundation II. a, Foundation. III, 224 Arciniega; b, Foundation II, 416-418-420 S. Presa. 
clayey suibsoti or "icebergs" of limestone bedrock protruding through the subsoil in various places. The cultural features noted above which disturbed the basic stratigraphy consisted of house foundations, pits (lined and unlined) and ditches, all of which were relatively straightforward to recognize and tsolate.

Organization of the Report

The balance of this report will present the results of the archaeological and historical investigations conducted during the course of the Arciniega Project. The organization represents something of a departure from the usual archaeological report. First, Catherine McDowell summarizes the results of extensive research concerned with the lives and fortunes of two of the Arciniega area's most distinguished early residents: Gregorio Arciniega himself and Vicente Micheli. Of particular concern were the precise locations of their respectivehouses, as this was deemed critical for an accurate historical assessment of the property on which the hotel was to be constructed. Following McDowe1l's historical highlights, the reader will proceed on a "walking tour" of the project area. Beginning at the corner of Durango and S. Presa, the discussion moves north on S. Presa, turns east onto Arciniega, then south on S. Alamo to Durango. Each address will be briefly considered archaeologically, architecturally and historically, as the data permits. The various cultural features outside foundations will be treated in a separate section, with an additional section by Anne Fox devoted exclusively to a description and interpretation of the cistern and possible cooling chamber designated Features 4 and $4 \mathrm{~W}$. The report concludes with a summary section, detailing the results of the archaeological and historical components of the Arciniega Project and assessing the significance of the area investigated. 
HISTORICAL HIGHLIGHTS OF NCBS 901 AND 155*

With the secularization of Mission San Antonio de Valero in 1793, its lands were partitioned among the Indians attached to the mission, the refugees from Los Adaes who had been living there, and residents of the municipality of San Antonio de Valero. Part of these lands were in an area known as the Lower Labor or Los Mochos.

When the Spanish soldiers from Alamo de Parras converted the former mission buildings into a military installation in 1801, many acquired homesites for their families in La Villita, a new little village located north of the Labor lands, south and east of the San Antonio River, and west of the road to the missions.

The revolutionary movement started in Mexico by Father Hidalgo in 1810 was immediately followed in San Antonio de Bexar by the short-lived Casas Rebellion, in which many of the local soldiers participated, resulting in confiscation of their lands by the governor. One of these rebels was Cayetano Dominguez.

\section{Gregorio Arciniega Property}

Sometime in 1811 Gregorio Arciniega, a retired soldier of the company of San Carlos de Parras, requested a parcel of land so he could erect a house and fence and cultivate the land. It was described as being in the "barrio de Valero, on the street leading to the lower missions, bounded on the east by said street, on the south by the land of Cayetano Dominguez, on the west by the land assigned to the militia, and on the north by Don Clemente Delgado's land" (Spanish Deed Records).

On November 14, 1811, the barrio chief, Vicente Gortari, agreed that there was no impediment to this since the particular area requested was confiscated and set aside by Governor Salcedo for lots and houses.

On November 25, 1811, Arciniega was granted 30 varas frontage from east to west and 60 varas depth from north to south, bounded on the north by Don Clemente Delgado's tract, calle por medio (street in between), on the west and south by public lands, and on the east by the road leading to the missions. Since the Delgado tract was located on today's NCB 114, the Arciniega land would have been south of Nueva Street and along South Alamo in NCB 155 (ibid.). Public lands were those that had been confiscated or assigned as militia lands by the Spanish government.

Additional proof that the Arciniega property was the eastern portion of NCB 155 (probably Lot 6 on the northeast corner) is given in a deed from Jose Antonio Delgado, son of Clemente Delgado, to John W. Smith, dated May 14, 1839, for a parcel of land in La Villita being 20 varas by 100 varas, bounded by Nueva Street, South Alamo, Arciniega Street and property of Maria Josefa Delgado (Smith n.d.). 
In 1841 Miguel Arciniega, son of Gregorio Arciniega, mortgaged the property to John Riddle as payment for goods purchased. In 1847 Riddle foreclosed the mortgage and took over the property (Bexar County District Court Records, BCDCR \#231).

In 1870 this property was involved in the law suit of Sarah Riddle Eager versus Estate of John Riddle, dec'd. Testimony of Francis Giraud in this suit states ". being the site in whole or part, of the present German and English School and being a part of what was formerly the property of Arciniega." In the testimony of Mrs. Elizabeth Riddle Canterbury, mother of Sarah Riddle Eager, she states, "I live on the corner of Alamo and Nueva Streets on a portion of the property in question. I have lived there from 1845 to the present time. It was mortgaged by Miguel Arciniega to Riddle about 1841 to secure payment for certain goods" (BCDCR \#3666).

Miguel Arciniega was a person of importance in both the Mexican and Texas Republics. In 1827 he was appointed by the Mexican government to lay out new towns for the Austin Colony and in 1832 he founded the town of Bastrop. He was a representative to the Coahuila-Texas legislature and in 1830 became alcalde of Bexar. On December 11, 1835, he acted as interpreter when General Cos surrendered to the Texans under Edward Burleson at Bexar, and in November 1836 was appointed Judge of the Municipality of San Antonio.

\section{Vicente Micheli Property}

On September 1, 1815, Vicente Micheli bought from the Spanish government a piece of land that had been confiscated from the insurgent Cayetano Dominguez. It was located in the triangular area formed by the crossing of the Concepcion and Madre acequias (now NCBs 902 and 903)(Bexar County Courthouse Deed Records, BCCDR [B-2]:198). On March 7, 1818, Micheli requested another portion of land (now NCB 901) between La Villita and his other property, said land to be added to his labors for cultivation. This request was granted on March 14, 1818 (BCCDR $[F-1]: 36-38$ ).

In 1847 this property was put up for sale by the Sheriff of Bexar County because taxes had been due since 1841. Part of this property was bought by Auguste Bonamy whose heirs sold to Thomas J. Devine and J. Hewitt (BCCDR [F-2]: 366-367). By 1850 al1 of NCB 901 was owned by Devine and Hewitt excepting the northwest corner which belonged to Juana Diaz (City Engineers Office, microfi $1 \mathrm{~m})$.

Devine and Hewitt began selling these lots in 1850, and by 1876 all but the four toward Alamo Street on the eastern end of NCB 901 (No. 3, 4, 5, 6) had been acquired by Heino Staffel. 


\section{STRUCTURES}

South Presa Street (NCB 901)

\section{6-430 South Presa (Hoerner House)}

As has been mentioned elsewhere, the construction of Durango Boulevard removed the southern portion of NCB 901. This included two lots fronting on South Presa which, in 1904, bore the addresses of "442" and "434" (Fig. 1) and which more recently were designated 438 and 432 South Presa. The house on the resultant corner of Durango and South Presa bore the address of "430" in 1904 (Fig. 1), but, at the time of urban renewal in the late 1960s was designated as 426 South Presa.

According to the data collected (Anonymous n.d.) during the course of urban renewal activities, "... this house was built by the Hoerner family in the 1880s or thereabouts. During its later years it was occupied by the Hoerner sisters who were school teachers. It is a good Victorian house of brick and limestone."

Three trenches, all components of the Trench 7 system, were cut in the vicinity of this structure (Fig. 2). The primary trench (7) was oriented east-west and was designed to explore the southwest extent of the proposed hotel foundation. The trench extended $22 \mathrm{~m}$ and was excavated to an average depth of $75 \mathrm{~cm}$. Two areas of rock were encountered (Fig. 4), an exposure of bedrock at the east end (provisionally designated Foundation IX) and a portion of cut limestone foundation toward the west end (designated Foundation VIII). Trench 7-North was cut perpendicular to Trench 7 for $5.75 \mathrm{~m}$ to explore the general area of a proposed hotel foundation pier (Fig. 2); no subsurface features were encountered. The purpose of Trench 7-West, oriented northeast-southwest and extending $7 \mathrm{~m}$, was to provide additional data on the structure associated with Foundation VIII. Forty centimeters below the asphalt, another portion of cut limestone foundation was encountered at the northeastern end of this trench; although designated Foundation XIII at the time, it and Foundation VIII together represent portions of the rear foundation wal1 of 426-430 S. Presa (Fig. 4).

Near the southwestern end of Trench 7-West, an anomoly in the trench wall profile was designated Feature 7 (Fig. 11); this feature is suspected to represent a former irrigation ditch, cut obliquely by the trench. Feature 7 will be discussed in greater detail in a subsequent section of this report.

The cultural material recovered as a result of trench cutting, and specifically in conjunction with the foundations, consists of construction rubble and domestic items dating from the decades around the turn of the century. All this material is considered to be associated with the $426-430 \mathrm{~S}$. Presa structure.

\section{2-424 South Presa (Phillip-Streiber-Staffel-Trebus House)}

This house (designated $424 \mathrm{~S}$. Presa in Fig. 1) was one of the three still standing on NCB 901 at the time of the investigations. No archaeological consideration was accorded this structure (Fig. 2): it was neither scheduled for immediate renovation and utility hookups (as was 204-206 Arciniega), nor was it involved in any historical controversies (as was 220 Arciniega). 
This is one of the 27 "significant" builaings in the La Villuta Historic District. The National Register of Historic Places inventory nomination form (Bel1, Hume and Williamson 1971) states the following:

27. Anton Phillip House (Staffel House), 422 South Presa Street. One-story, Victorian cottage.

Preliminary urban renewal research (Anonymous n.d.) states the following:

This house is part of the Staffel estate but was not their homestead. It was probably built before the turn of the century for one of their children. It is a Victorian brick house with a tin roof and Grecianlike columns. It is named for a member of the Staffel family who was named Streiber.

An architectural survey (Garner 1969:86) of the area-conducted as part of the Historic American Buildings Survey states, however:

This house, known as the Anton (also Adolph) Phillip house, is as yet undocumented. In 1910 Phillip was listed as living at 416 South Presa (now 412), which would be the second house north of this one. At this address (422), the 1910 directory listed H. and Emmy Trebus.

The house is "L" shaped, with brick walls, metal-clad intersecting gable roof and a two-bay front porch supported by wood columns with ornate composite capitals. Notable features are the segmented arch window openings and hood molds.

The above survey indicates the construction date to be about 1890 .

A city directory for 1895-96 shows this house to be occupied by Mrs. Mary Elmendorf. Various subsequent records, including city directories and the estate documentation of Adeline Staffel, indicate that Emmy Trebus, Mary Elmendorf's sister, occupied the house at 422-424 South Presa for several decades. This structure seemed always to have been in the general Staffel family.

\section{6-418-420 South Presa (Kuhn House)}

Bearing the address "420" in 1904 (Fig. 1), the following information is provided (Anonymous n.d.) about this house: "The property was sold at auction by Guadalupe Leal to Barbara and Jacob Kuhn on March 17, 1883. House was probably built soon after this date." The house and lot were soon absorbed into the growing Staffel holdings on NCB 901; in 1895 Eugene Staffel was the resident, as was Mary Elmendorf in 1906. It is not certain when this single family dwelling was converted to a duplex, the situation in effect at the time of its demolition. Archaeological evidence suggests it was suited for this purpose, however.

The entire exterior and interior edges of the 416-418-420 South Presa foundation were exposed during the investigations, designated Foundation II in Fig. 4. Figure 6 presents a plan drawing of the exposed cut limestone rock foundation. Notable is an interior foundation wall which bisects the structure into north and south halves, each half provided with a stone fireplace (Fig. 5,b provides a 


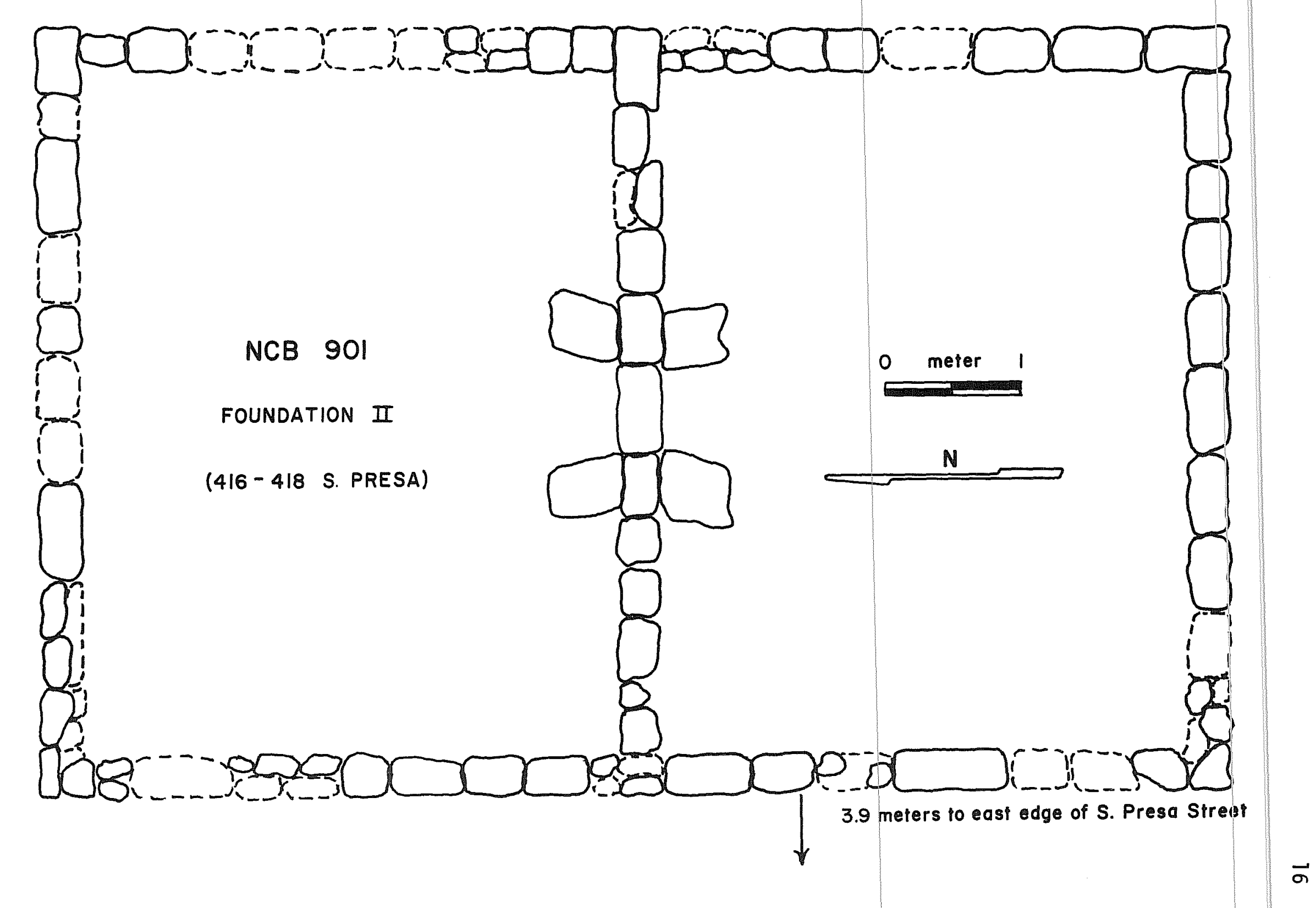


detail of this feature). Each half of the house is a complete unit structurally, suitable for independent habitation. The few artifacts recovered in association with Foundation II represent the turn of the century, as would be expected.

\section{2-416 South Presa (Leiber-Phillip House)}

Bearing the address "416" in 1904 this house seems to be the farthest north with a South Presa address on NCB 901 (Fig. 1). The Historic American Buildings Survey inventory sheet (Garner 1969:63) states the following:

It appears from the 1873 drawing of San Antonio by Augustas Koch that a small cottage was located on this site at that time. The present house apparently incorporated this structure at a later date. Although this house is as yet undocumented, it can be dated by its style and details to ca. 1885. It appears on a Koch drawing of 1886 and therefore is prior to that date.

The house is "L" shaped with stuccoed limestone walls, metal-clad intersecting gable roofs and three-bay front porch supported by chamfered wood posts with scroll-saw bracket capitals.

Anton (or Adolph) Phillip apparently occupied this house for a significant period of time.

As was the case with 416-418-420 South Presa, the entire foundation of 412-416 South Presa was cleared and recorded; both operations were possible due to this portion of NCB 901 being in grass rather than under an asphalt pavement. Designated Foundation I (Fig. 4), artifacts associated with 412-416 South Presa are similar to those recovered from other foundations along this block of South Presa, falling into the turn of the century period (ca. 1890-1910).

Arciniega Street (NCB 155)

215 Arciniega (Cosgrove House)

A1though the western portion of NCB 155, Lot 30 was not scheduled for subsurface disturbance in connection with the hotel construction, a short period of time at the end of the field session was allocated for limited archaeological investigations. The purpose was to provide additional evidence, either positive or negative, toward the resolution of the "cuartel question."

Historical research by Santos (1967) and archaeological investigations in 1969 by Schuetz (n.d.) concluded that the stone ruins of a stable at the northern end of former Lot 26 were probably the remains of a Spanish Colonial barracks, or cuarte1, possibly constructed in 1809 and destroyed in 1836 (Santos 1967). Various documents of this period in the early 19th century refer to portions of NCB 155 as "public lands" or "lands belonging to the military;" and "the preliminary examination of the area in February, 1965, resulted in the discovery of impressive ruins of dubious origin thought to be Spanish colonial in nature and surprisingly matching Adam 's specifications for rooms 12 and 13 of the Quartel" (5antos 1967:197). The 1969 excavations did not resolve the question of whether the stable ruin was part of the original cuartel complex, only that it was not an integral part of a larger structure as Santos had surmised. 
Despite Luckett's (n.d.) Tengthy rejoinder to the above research, detailing her firm belief that the ruin on Lot 26 of NCB 155 was not the remnant of a Spanish fort, it was decided to follow the recommendation of Schuetz (n.d.:39):

There is a possibility that the extent of the cuarteles could be determined through further archaeology. Mr. Cosgrove reports that when the owner of the cab company razed the buildings on the southeastern corner of Block 155, he left the foundations below grade. By stripping off the two layers of asphalt and exposing the foundations, the number of buildings within the cuartel complex might be determined. The nature of the cuartel enclosure might also be determined.

Neither time nor backhoe funds were available to permit an extensive trenching of all of Lot 30; and it must be admitted that the "southeastern corner" referred to above, comprising the former Lots 1,2 and 3 , was not investigated. All that was accomplished was to cut a trench (designated Trench 16) $30 \mathrm{~m}$ long diagonally across Lot 26 from northeast to southwest; only the basement of the Cosgrove House was documented.

Trench 16 does not appear in the Fig. 2 insert, although the Cosgrove House and stable wall ruin show as Foundations XVI and XVII, respectively, in Fig. 4 . A photograph of the stone stairs leading into the basement is provided as Fig. 7,a. Trench 16 exposed the top three stairs and portions of the foundation on two opposing sides; the backhoe proceeded to excavate the entire basement fill and outline the entire circumference of the foundation. This was done to explore a suggestion made by Schuetz (n.d.:38):

In conclusion it can be said that all evidence examined indicates that the excavated stable and the one torn down in the 1950s (on Lot 1) were the last buildings of the Spanish cuarteles. Whether these were the only buildings is not known. There is a possibility that the CarrKrakauer-Cosgrove home may have incorporated a third building. The stone construction in a block of mostly adobe and jacal constructions and $\mathrm{Mr}$. Cosgrove's description of the basement built of limestone blocks put together with wooden pegs certainly suggest the possibility, plus the fact that the house was oriented in conformity with the stables and Arciniega Street rather than with the boundary lines of the lot.

The basement and foundation were indeed constructed of large limestone blocks, blocks with cut grooves to hold wooden pegs. Associated artifactual material, however, ranged in age from a scrap of newspaper dated "1960" to a variety of domestic items common in the latter quarter of the nineteenth century. The cultural material parallels the history of Lot 26. According to Schuetz (n.d.:37):

Lot 26 was formed by the purchase of the back of Lot 1 on Arciniega Street by Sarah and Robert Eager from Franz Schaeffer. The Eagers sold this lot and the whole of Lot 2 to Sarah and A. B. Frank in 1873. Lot 26 was completed with Sarah Frank's purchase from Nicholas Cosgrove of the western portion of Lot 2 . Lot 26 subsequently was owned by James and Blassa Carr, Max and Minna Krakauer, and, finally, Nicholas J. Cosgrove in 1889. 


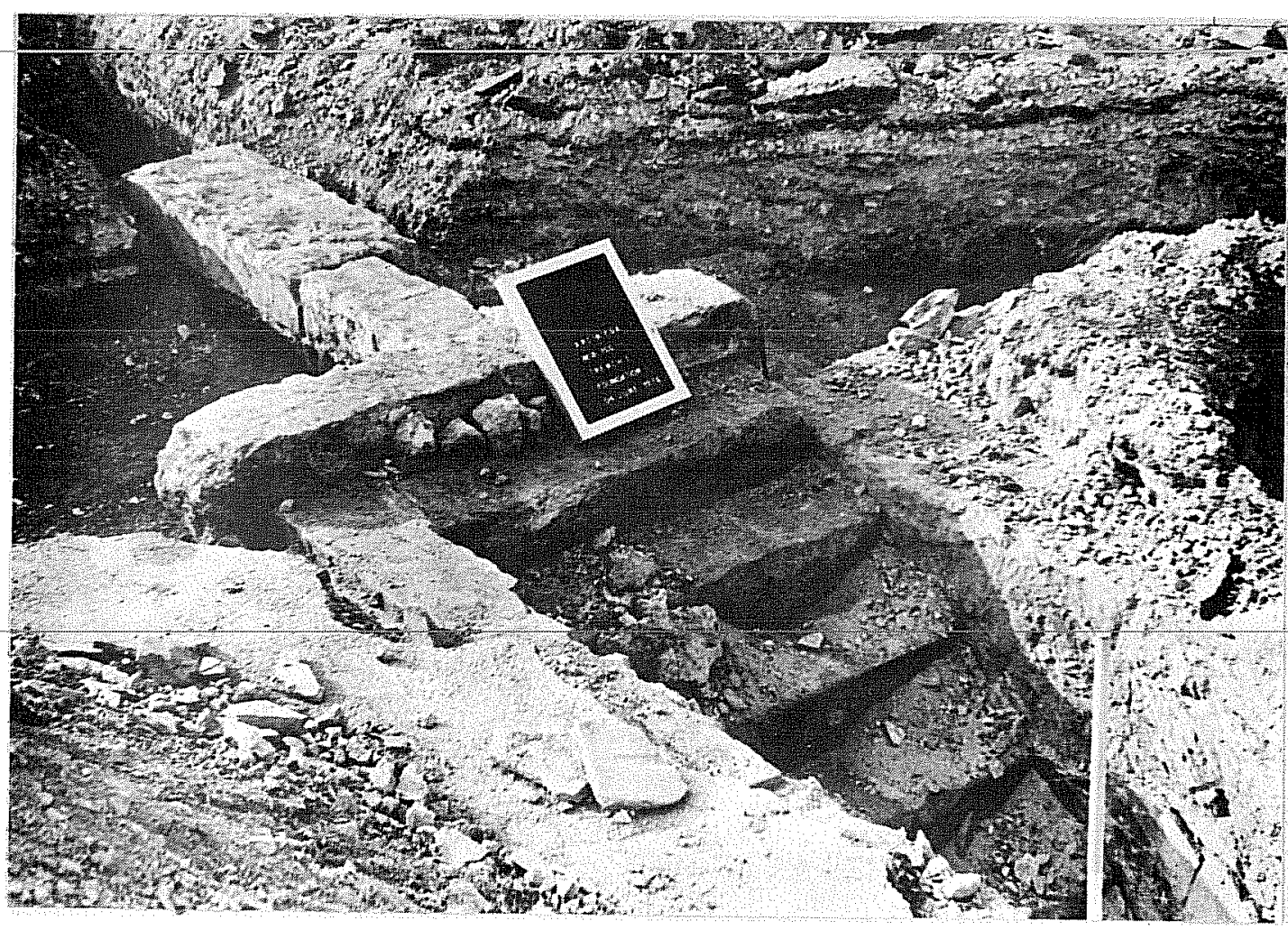

a

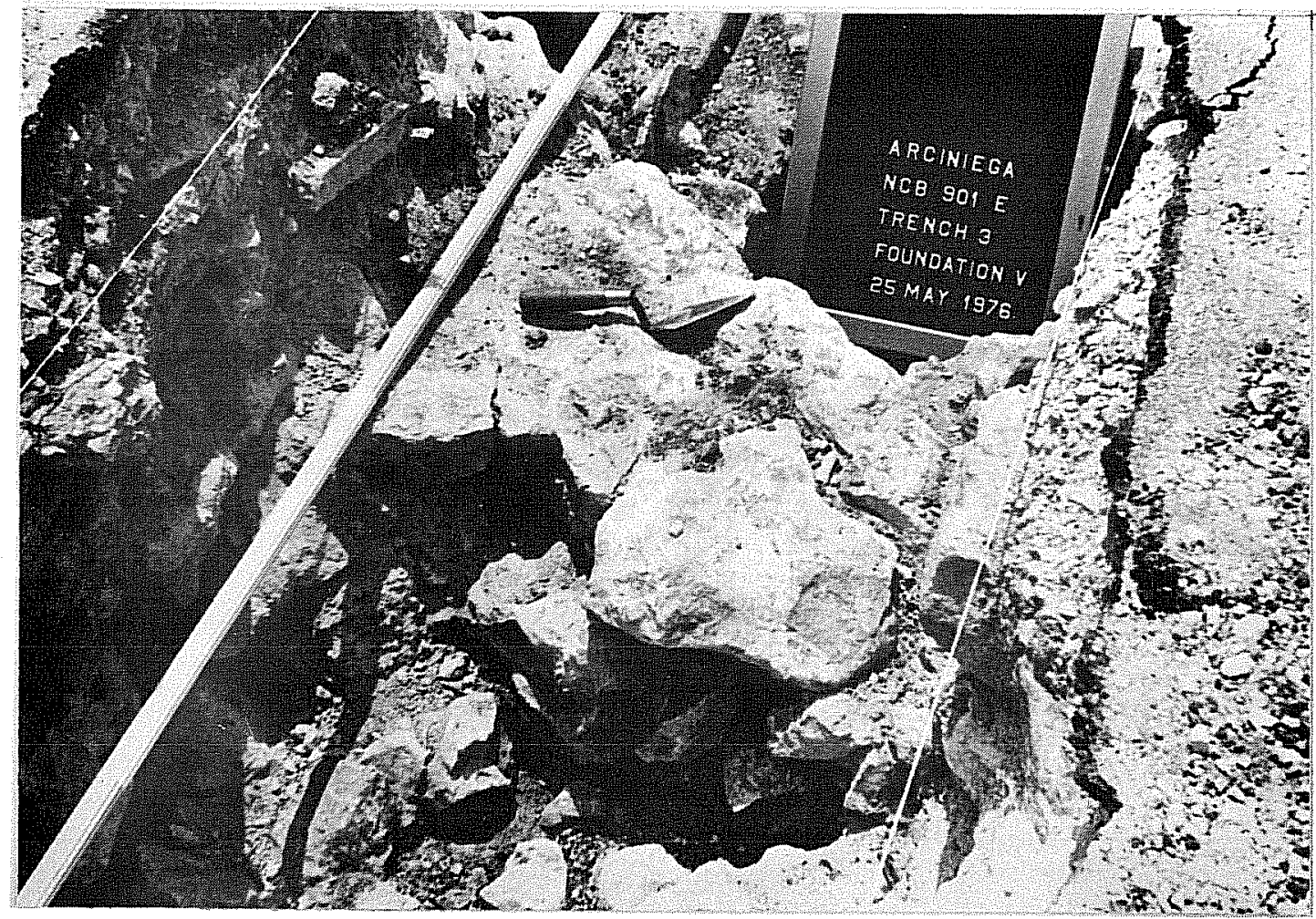

b

Figure 7. Portions of Foundation XVI and Foundation V. a, Foundation XVI (215 Arciniega); b, Foundation V (224-226 Arciniega). 
Since Schuetz's informant was James Cosgrove, grandson of Nicholas, who grew up in the house, it was built in or before 1889. This corresponds to the earliest artifactual material recovered from in and around the structure.

The question of the cuartel--whether it was ever constructed, and if so, where it was located--was not resolved. The 1976 excavations on Lot 26 (now Lot 30) of NCB 155 have simply eliminated the area immediately south of the stable ruin as a possible location. It should be mentioned that the historical research component of the Arciniega Project did address this problem as well, covering much the same ground as Santos, Schuetz and Luckett. The location of the cuartel (but not the fact of its existence) was approached peripherally in conjunction with attempts to locate the house of Gregorio Arciniega. As the above discussion by Catherine McDowell indicates, Arciniega's house most likely stood on Lot 6 of NCB 155, the lot at the corner of $E$. Nueva and S. Alamo. Since Arciniega's house seems pivotal to the cuartel's location, it now seems possible that, if a cuartel existed, it would be located in the immediate vicinity of the German-English School. It would be difficult, unfortunately, to pursue archaeological investigations under such an extensive structure.

Arciniega Street (NCB 901)

200-204-206 Arciniega (Diaz House)

This is one of the 27 "significant" buildings in the La Villita Historic District. The National Register of Historic Places inventory nomination form (Be11, Hume and Williamson 1971) states the following:

24. Diaz House, 206 Arciniega Street recorded by HABS, stucco-covered double house. In poor condition.

Research into the relationship of Juana Diaz with the house bearing that name at the corner of South Presa and Arciniega (Fig. 1) proved interesting in its variations. According to the Historic American Buildings Survey (Garner 1969:28):

This structure, currently doomed by an Urban Renewal project, has not yet been documented; but by its appearance it may be dated ca. 1878 .

It is rectangular with stuccoed limestone walls, a low sloping metalclad gable roof and a five-bay gallery extending across the north front supported by box piers.

The report on structures in Urban Renewal \#5, Extension Area (Anonymous n.d.) states, however:

No mention can be found of a house on this property prior to its purchase by Juana Diaz in 1851. The house was probably built fairly soon after her acquisition of the property, and her abutting neighbor in $1856 \mathrm{de}-$ scribed his property as being east of house and lot formerly belonging to Juana Diaz. 
Finaily. there is Macivitian (1972:2), who takes into account the two sources above and adds a great deal of personal research. It seems a Juana Dlaz appears in the Headrights record in 1837 and aga in in the deed records in 1847. In any event, Juana Dlaz sold her property to Thomas J. Devine on July 22, 1854, although there may not have been a house on the property. No house appears on this lot in Koch's 1873 Birdseye View map; the existence of a structure on Koch's 1886 map seems to correspond with the HABS report of an approximate 1878 construction. MacMillan (1971:2) states that "the city directory of 1877-78 shows Rafael Diaz, Cigars, Tobacco and Jewelry, Alamo Plaza and Commerce; residence south side of Arciniega between Alamo and Presa." The relationship between Juana Diaz and Rafael Diaz is not known, but it seems as if the original owner of the land and the owner of the property's first structure perhaps 40 years later did have the same surname.

The Diaz House at 206 Arciniega (also numbered "200" and "204" in the past) was one of three still standing at the time of the archaeological field work. As it was the only one of these existing structures undergoing renovation at that time, precise locations of utility lines were available for only this house. Trenches 1 and 2 were excavated to bedrock, each beginning $2 \mathrm{~m}$ beyond the structure and proceeding to the foundation (Fig. 2). Unit $A$, a $2 \mathrm{~m}$ square, was situated at the edge of a proposed French drain construction on the south side of the house (Fig. 2), and also extended to bedrock. Recovered artifacts with chronological potential, especially glass and ceramic fragments, do not seem to be any older than the last quarter of the 19th century, further substantiating the construction of the Diaz House ca. 1878.

\section{8-210-212 Arciniega (Staffel House)}

This house has borne the addresses of "208" and "212," the latter showing on Fig. 1. According to MacMi11an (1971:7):

On November 9, 1850, Thomas J. Devine sold this lot to Theodore Herber and Charles Baldus who in turn sold, in February 1852 to John B. and Philip Conrad. In default of payment, this property... house and lot . . . was sold at pub7ic vendue to Nat Lewis on November 5, 1854. On May 1, 1855, Nat Lewis sold to Justin McArthy. McArthy (and James Duff), for $\$ 2,250.00$ sold this same property to Heino Staffel on October 14, 1862 . . The property stayed in the Staffel family . .

From the above it can be assumed that the house was constructed prior to November 1854, but most likely after November 1850. The estate of Adeline Staffel left Lot 1, including the house at 208-210-212 Arciniega, to Bertha Staffel in 1912, and MacMillan seems to feel that Heino Staffel was residing at this address in 1878-79.

Archaeological investigations were not conducted in the immediate vicinity of 208210-212 Arciniega, although on reflection this may have been an oversight. Subsequent research has indicated that this house may have been one of the earlier structures on the block, although it does not appear on Koch's 1873 map. The closest approaches made by the 1976 excavations occur at the west end of Trench 3 and the north end of Trench 9 (Fig. 2). The foundation designated XI at the west end of Trench 3 is bedrock, exposures of which were assigned provisional foundation numbers prior to detailed observation. No structural remains were noted in 
the north end of Trench 9. The irregular pit designated Feature 9 and suspected to be a latrine is indeed located at the rear of 208-210-212 Arciniega (Fig. 11), but it is also positioned so as to be at the rear of both 412-414 and 416-418$420 \mathrm{~S}$. Presa. It will be discussed in greater detail in a subsequent section of this report.

\section{8-220 Arciniega (Arciniega-Elmendorf-Tylor House)}

Al though at some time numbered "218," most sources agree that this house is "220" (Fig. T). The disparity in historical documentation of original ownership is much more significant, however, in that it concerns the notable Arciniega family. The statements in the report of structures in Urban Renewal \#5, Extension Area (Anonymous n.d.) are in themselves contradictory:

This house was built by one of the leaders of the Texas Revolution, Miguel Arciniega of the Arciniega family ....

The land upon which this house was built was acquired by Miguel's father, Gregorio Arciniega, from the Spanish Government in 1811, who built the house at that time.

The Historic American Buildings Survey (Carter 1969:6) expresses skepticism concerning the Arciniega association by placing the name of the house in quotes: "Arciniega House." It states that:

In recent years this house has been called the Arciniega House, allegedly erected by Miguel Arciniega, a prominent citizen during the second quarter of the nineteenth century in San Antonio; however, the documentation has yet to be done to substantiate this information.

This house is one of the few of its type now remaining in San Antonio, a type that was once very common, and is characteristic of its type. It is a small rectangular structure, stuccoed masonary walls, and gabled roof at the rear. This structure is deserving of further research and preservation. Within the last year the immediate neighborhood has been systematically stripped of the few remaining nineteenth century buildings by Urban Renewa1.

The date of the house is given as ca. 1850 .

Research on this very problem of the location of the Arciniega house was conducted by Catherine McDowell and is summarized elsewhere in this report. The conclusion is that Arciniega built and lived on Lot 6, NCB 155; that is where Arciniega's house was. Supporting evidence for where it was not is found in a letter from Armin Elmendorf to Esther MacMillan, dated December 4, 1873. It reads in part:

The next time you pass the old adobe house at 220 Arciniega, which my grandfather Heino Staffel built in the early 1850's, take a look at the live oak tree adjacent to the house. This tree grew from an acorn that was planted by a grandson of Heino Staffel, namely myself, in about 1895 . 
Both of my grandparents were pioneers in San Antonio. One went into the harness and leather business, and the other, Charles Elmendorf, into the hardware business.

The construction date of ca. 1850 given on the HABS report is consistent with the Elmendorf letter, making the house at 218-220 Arciniega most likely the second oldest dwelling on the block. Despite its construction by Heino Staffel, the long-time residence of Elmendorf is well documented. An 1877-78 city directory shows Charles Elmendorf at this address, and Adeline Staffel's estate left the house and lot to Mrs. Charles Elmendorf.

It is indeed fortunate that this house is one of the three left standing on NCB 901. This is in keeping with the thoughts expressed in the HABS report quoted above and obviously with the feelings of the family and other interested parties.

To quote-the-Urban-Renewal report again:

It still has its original pegged floors, and until recently was occupied by Mrs. Stella Elmendorf Tylor (sic), who received an award from the San Antonio Conservation Society for preserving it, and its old Texas garden.

It should be noted that this is one of the 27 "significant" buildings in the La Villita Historic District. The National Register of Historic Places inventory nomination form (Be11, Hume and Williamson 1971) states the following:

25. Elmendorf House, 220 Arciniega Street Elmendorf-Taylor (sic) House, also known as the Arciniega House. Circa 1811, stuccocovered double house with center chimney and a pedimented porch.

At the time of the field work, plans had not yet been drawn for renovating 218220 Arciniega, and testing the specific locations of utility hookups was not possible. Because of the uncertainty at that time of the date of its construction, however, one trench was cut to expose a portion of the foundation and to explore the adjacent yard. Following MacMillan's (1971:9) statement that "Gregorio's son, Miguel Arciniega, is said to have built the original house toward the rear of this site," Trench 12 (Fig. 2) extended $6.5 \mathrm{~m}$ toward the southeast, beginning at the east wall of the rear portion of the house. Bedrock, provisionally designated Foundation XIV (Fig. 4), appeared along the entire floor of the trench, except where it had been pierced by a man-made pit. Designated Feature 12 (Fig. 11), this pit will be discussed in greater detail in a subsequent section. Neither the construction details of the foundation nor the very few artifacts recovered from the trench provided information toward the "Arciniega" problem, the solution coming from the historical research component of the project. No structural remains were encountered in Trench 12 away from the foundation of 218220 Arciniega itself. The only other archaeological association with this house has been designated Foundation IV (Fig. 4), a section of a concrete slab uncovered near the West end of Trench 3 (Fig. 2). This is interpreted as a portion of a driveway of recent vintage.

\section{4-226 Arciniega}

Very little can be said about the structure at this address, as it seems to have been slighted by most sources concerned with Arciniega Street and NCB 901. 
Mackillan (1971) does not consider it, aithough it appears, correctly numbered, on copies of both the 1904 (see Fig. 1, this report) and 1924 Sanborn Insurance maps included in her report. The Urban Renewal Structures report (Anonymous n.d.) discusses the 224 Arciniega address, but it is most likely referring to the house at 228 Arciniega next door. The house does not show on the 1873 Koch map, but a city directory for 1887-88 1 ists Eugene Staffel as residing at 226 Arciniega, which most likely is now "224." An assumption can be made that the house was constructed in the 1880s, by and for the Staffel family. This would correspond to the period during which the spate of house construction was occurring along $S$. Presa Street, all four houses on this street on NCB 901 being built between 1880 and 1890; in addition, the Staffel family was continually expanding its holdings on this portion of NCB 901 .

Corroboration for the construction of 224-226 Arciniega during this decade can be obtained from the archaeological investigations. Trench 3 (Fig. 2) was oriented east-west to explore the northwestern wing of the-proposed hotel-Extending $35.25 \mathrm{~m}$, its eastern half cut across the former location of 224-226 Arciniega, exposing portions of foundation structure designated Foundations III and $V$. Foundation III ( $\mathrm{Fig} .5, \mathrm{a}$ ) was represented by a section of concrete slab, lying horizontally on bedrock approximately $25 \mathrm{~cm}$ below the asphalt. Foundation $\mathrm{V}$ (Figs. $7, b ; 8$ ) is a section of foundation wall composed of 1 imestone rocks bonded with patches of cement. Portland cement was not introduced to San Antonio until 1880, when the Alamo Roman and Portland Cement Company began operations at what is now the Sunken Gardens in Brackenridge Park. Artifactual material associated with these two foundation portions consists of construction and household debris covering a broad temporal range, but no item can be firmly dated prior to 1880 .

As possible further evidence for an 1880-1887 period during which 224-226 was constructed. there is the cistern and cooling chamber (Features 4 and $4 \mathrm{~W}$ ) now situated on this same lot. Discussed by Anne Fox in greater detall in a subsequent section, it can be stated brfefly now that the filling occurred after 1880 although part of its construction probably pre-dates this. Fox is of the opinion that Feature 4 (the cistern) was built initially for use by the residents of 228 Arciniega; Feature 4W, the cooling chamber, was built and used later by the residents of 224-226 Arciniega after the feature was incorporated into their lot. The 224-226 Arciniega residents then filled both portions of the feature at still a later date.

\section{Arciniega (Micheli House)}

This house on Lot 4 of NCB 901 is, according to all available documentation, the oldest domicile on the block. As might be expected from foregoing discussions, however, there are discrepancies as to whether different portions of the total structure were built at different times or all at the same time.

The Urban Renewal Structures Report (Anonymous n.d.) states the following:

According to title, grant came from State of Coahuila and Texas on March 13, 1818. The house was probably built in, or around, 1842 by slave labor. The builder is not known, but it was part of the Micheli holdings. Colonel Gibson, present owner, had to replace the original flooring because of poor condition, but retained some of the boards between archways in the house. 


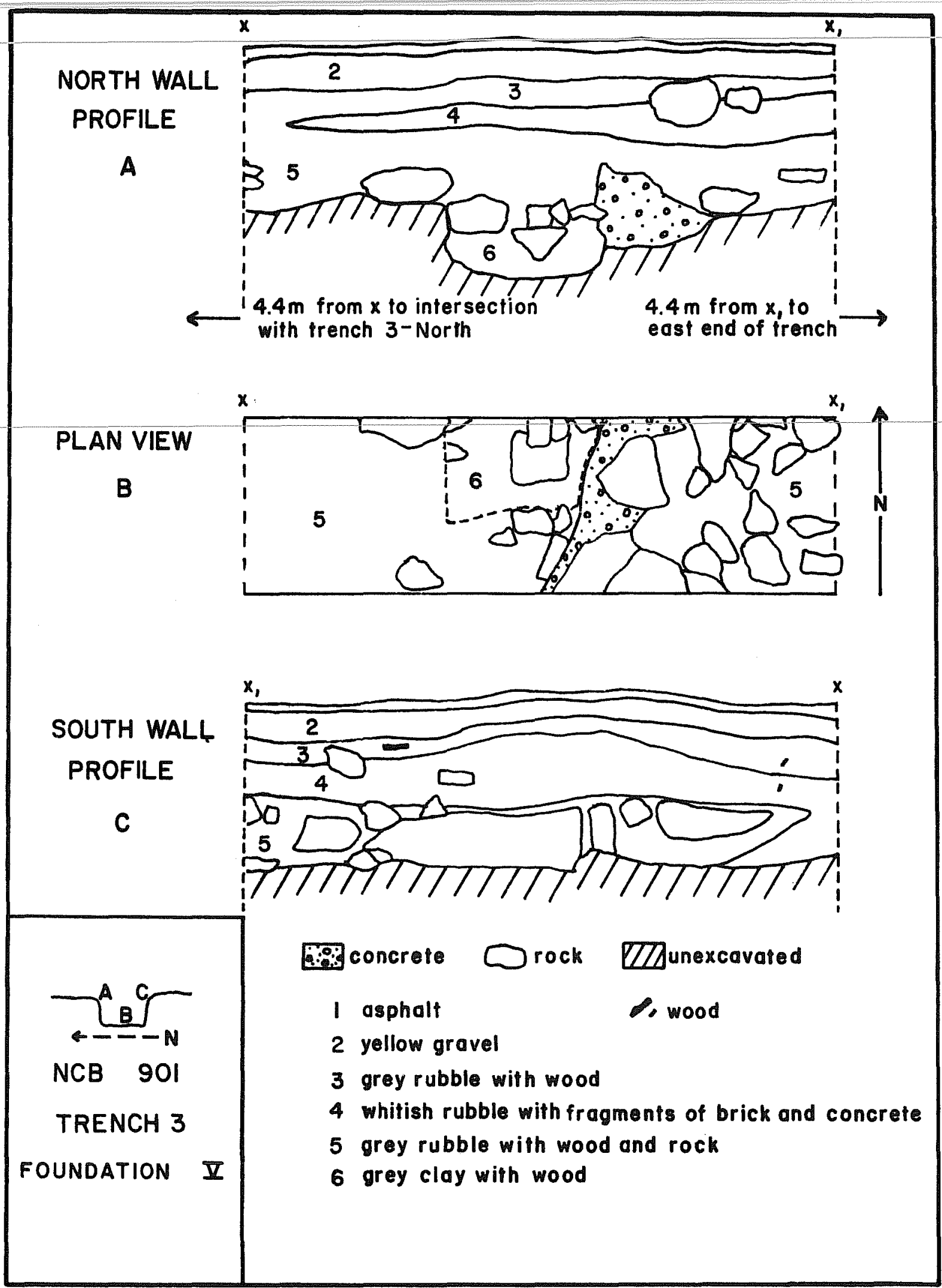

Figure 8. Plan and Profiles of a Portion of Foundation V (224-226 Arciniega). 
Macmillan's (7977:71) summary of the structurat history of 228 Arciniega is as follows:

A house in the back of this property was said to have been built by Cayetano Dominguez in 1810. He was a Spanish insurgent who joined local revolutionary movements against Spain between 1811 and 1813. His property was confiscated during this period by the Spanish government and sold at auction to Vicenti Micheli. Micheli built upon the original Dominguez house and later borrowed money from John Twohig and others to build a two-story limestone structure in 1841. Being unable to repay the money, he lost most of his property before his death in 1848. At the side of the two-story house was an old gazebocistern structure and in back a Victorian outhouse, circa 1840, both structures being possibly the oldest of their kind in San Antonio.

Catherine McDowel!'s historical summary, presented elsewhere in this report, agrees in general, if not in detail, with the facts surrounding Micheli's ownership of the property presented above. The problem that was addressed during the archaeological investigations concerned the construction chronology of the component parts of 228 Arciniega. Figure 1, the 1904 Sanborn Insurance Map, shows an "L" shaped plan; the foot of the "L" fronting Arciniega Street was the two-story house generally agreed to have been built in 1841 or 1842 . It is the north-south portion at the rear, one-story high, which may have been built originally by Dominguez in 1810, rebuilt or added to by Micheli in 1818, or simply a contemporaneous wing of the two-story 1841-42 structure.

The Trench 10 system (Fig. 2) was therefore cut to locate and expose aspects of this rear portion of 228 Arciniega. The primary trench (10), oriented northeastsouthwest and extended $8 \mathrm{~m}$, exposed portions of the east and west foundation of what proved to be the southernmost of four separate "rooms" (designated Foundation XII; Fig. 4). Additional members of Trench 10 were cut to expose the exterior face of this south room foundation on the west, south and east; and a two-meter square (Trench 10-North) was excavated inside the south room foundation to bedrock (Fig. 2). To establish the relationship between the southernmost room and suspected rooms to the north, the Trench 13 system was also cut (Fig. 2). The primary trench (13) extended $12.5 \mathrm{~m}$ east-west across what is designated the "north room," exposing a portion of the east wall foundation (Foundation XV; Fig. 4); Trenches 13-North and 13-South, with a combined length of $25.5 \mathrm{~m}$, cut across portions of the dividing walls between each of the four rooms and the foundation of the two-story "front" portion.

Attempts to reconstruct the interior dimensions of the various portions yielded the following: the two-story front portion measured $9.4 \mathrm{~m}(31 \mathrm{ft})$ north-south by $7.0 \mathrm{~m}(23 \mathrm{ft})$ east-west; the north-south dimensions of the north, northcentral, south-central and south rooms at the rear were $4.9 \mathrm{~m}(16 \mathrm{ft}), 3.0 \mathrm{~m}$ $(10 \mathrm{ft}), 4.2 \mathrm{~m}(14 \mathrm{ft})$ and $4.9 \mathrm{~m}(16 \mathrm{ft})$, respectively; and al1 four rear rooms were $4.2 \mathrm{~m}(14 \mathrm{ft}$ ) wide east-west. The width of the foundations of al1 portions varies only $1 \mathrm{~cm}$, between 63 and $64 \mathrm{~cm}$ wide.

Figure 9 shows different views of the southernmost room, the one most fully exposed by trenching activities; Figure 10 provides a detail of the exterior face of the foundation. No evidence of mortar remained between the foundation stones, although traces of sand in some spots may suggest its former presence and 


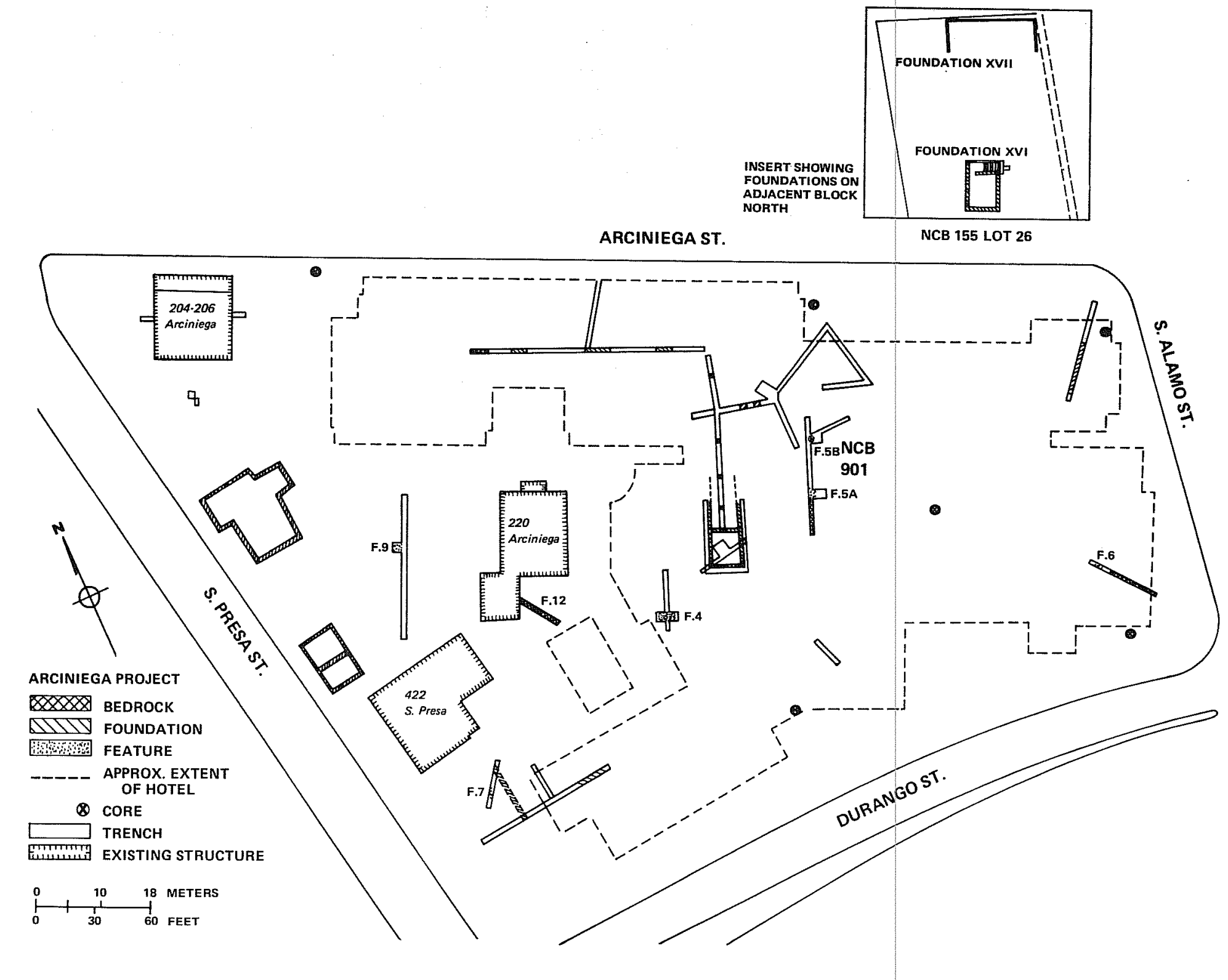

Figure 11. Location of Excavated Features. 


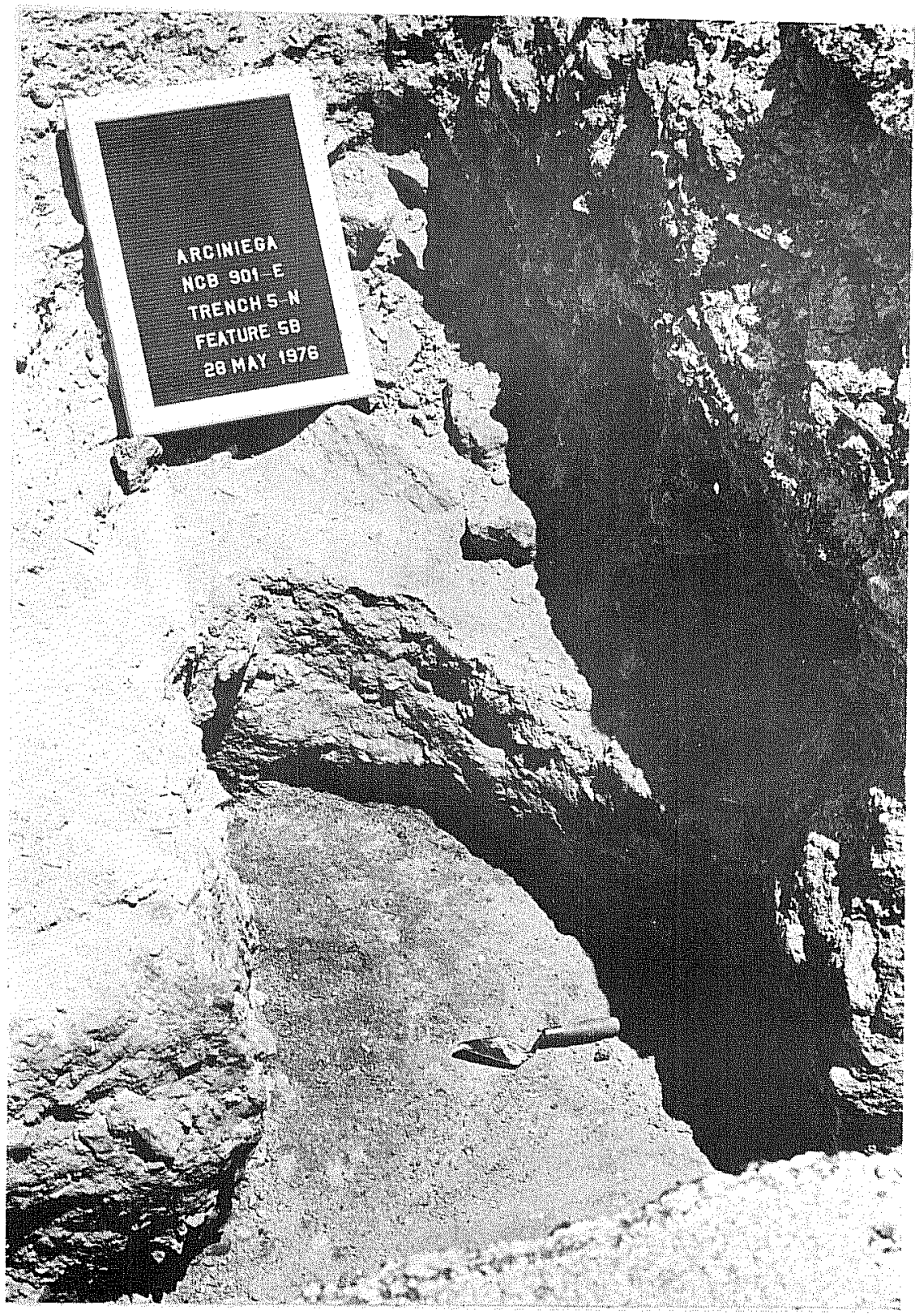

a

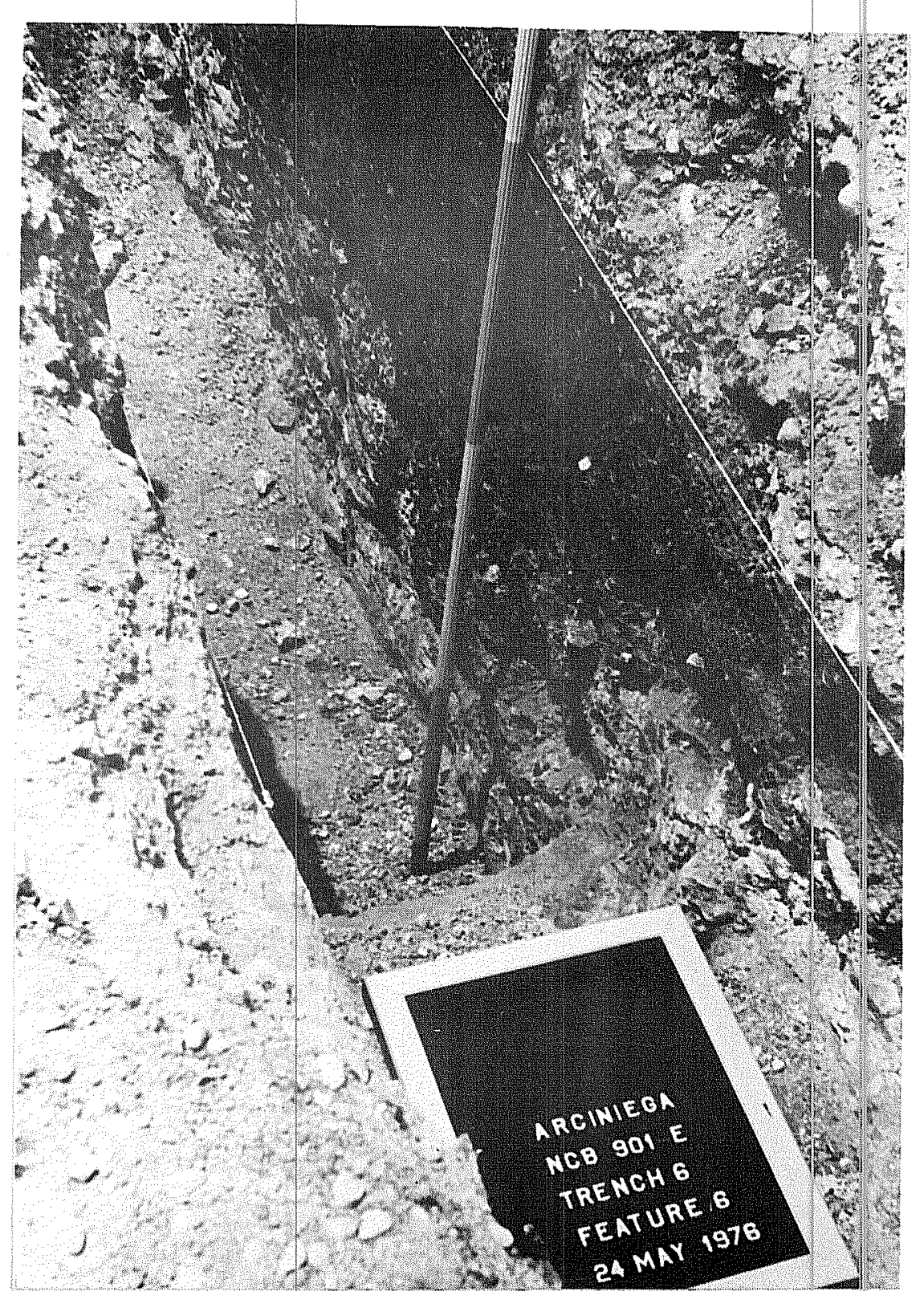

b

Figure 12. Excavations of Feature $5 B$ and Feature 6. a, Feature $5 B$, looking southeast; pit floor at $140 \mathrm{~cm}$ below asphalt, in Trenches 5 and 5-North; $b$, Feature 6, looking north; feature appears in profile in the wall of Trench 6. 


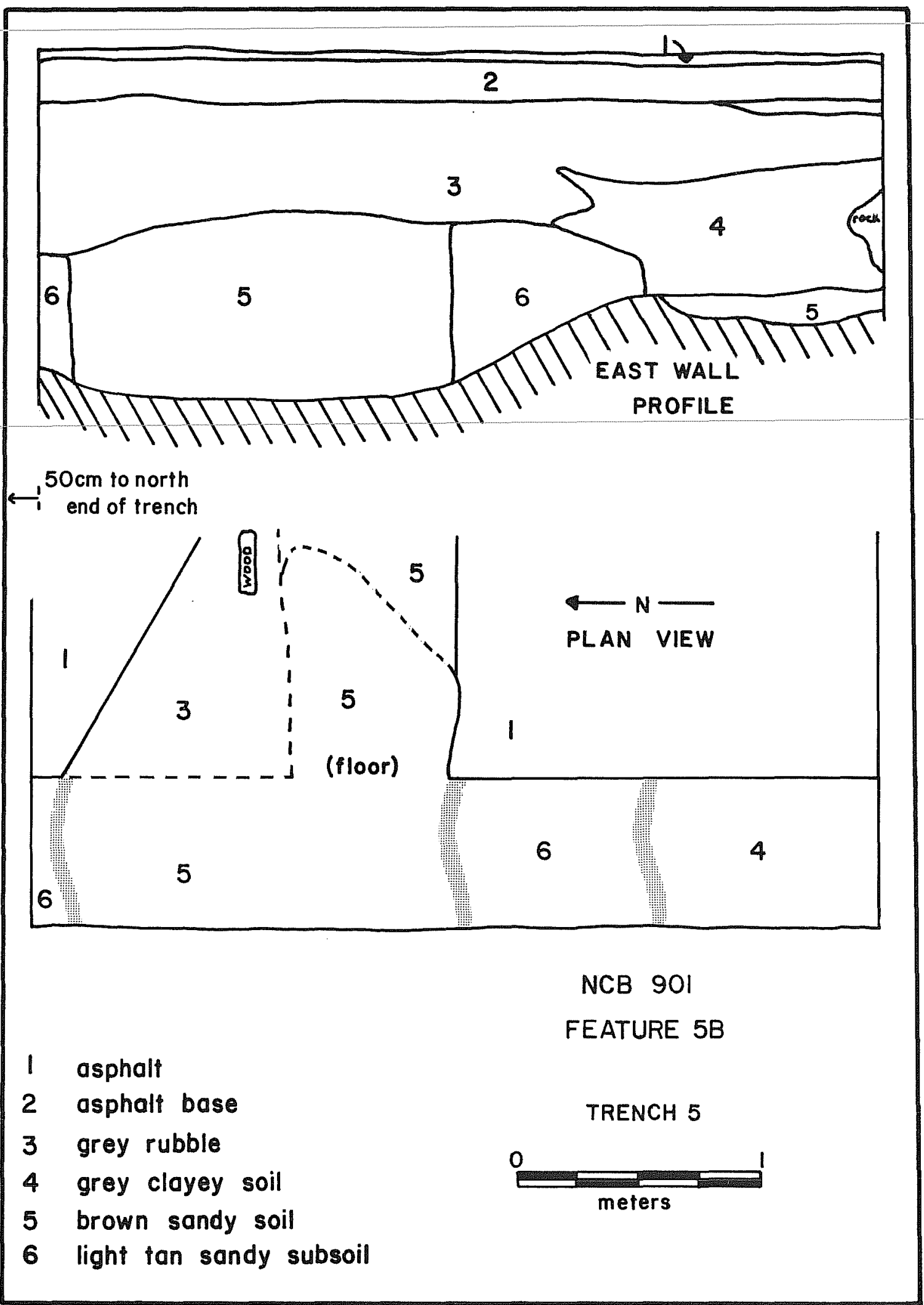

Figure 13. Plan and Profile of Feature 5B. 
Artifacts associated with the pit fill consist primarily of glass, ceramics and construction items such as nails and wire. The latter were recovered close to the top and are suspected to have intruded from the rubble zone covering the mouth of the pit. The glass and ceramic items fall generally into the pre-Civil War period of the 1840s and 1850s. Also recovered were over 500 pieces of mammal bone, mostly unidentifiable fragments; cow and fox squirrel were the two recognizable animals.

The size and shape of the pit, the nature and dating of its contents, and its location close to the kitchen area of 228 Arciniega all combine to support its interpretation as a refuse pit associated with the first several decades of the Micheli House.

\section{Feature 6}

The interpretation of this feature is the same as that of Feature $5 A$, a ditch which most likely served an irrigation function. It appears in profile in both walls of Trench 6 (Figs. 2, 11), cut very obliquely so that its true dimensions are difficult to measure. Figure 12,b provides a photograph and Fig. 14 profile drawings. The ditch was cut into the gray clayey subsoil to a depth of about $85 \mathrm{~cm}$ and is filled (perhaps silted up) with lighter gray and brown silty clays having inclusions of shell and various organic materials. The ditch appears to begin about $60 \mathrm{~cm}$ below the present ground surface (asphalt) and is $123 \mathrm{~cm}$ at its deepest point. Width cannot be determined because of the conic section nature of the trench-ditch intersection. No artifacts were found in association with Feature 6.

\section{Feature 7}

This feature represents a third possible irrigation ditch, having much the same characteristics as Features 5A and 6: an intrusion of lighter, sandier soil into the gray clayey subsoil, having the configuration of a ditch in profile. Feature 7 was cut obliquely by Trench 7-West (Figs. 2, 11), again making measurement difficult. Figure 15, a provides a photograph of the trench wall, Fig. 16 a profile of this wall. The edge of the ditch is currentily $23 \mathrm{~cm}$ below the asphalt pavement, its deepest point at $77 \mathrm{~cm}$.

Feature 7 differs from the other two possible ditches, however, in that some documentation exists concerning it. On a map drawn by Francis Giraud in 1850 on file in the City Engineer's Office, a ditch is shown cutting across what is now NCB 901. The approximate line of this ditch is shown in Fig. 1 , and it could very well be the ditch recorded as Feature 7. Giraud's ditch appears to connect the Pajalache (Concepcion) and Madre acequias, which run close to the west and east sides of NCB 901 and intersect only one block south. It is postulated that Feature 7 represents a primary acequia lateral, with Features 6 and $5 A$ representing portions of secondary laterals. In this way the entire block would receive water for agricultural irrigation.

It is regrettable that no means were available to date either the construction or termination of the ditch system; it must suffice to have illuminated this non-structural but culturally significant facet of NCB 901 activity. 
NCB 901
FEATURE 6

7 light tan clay subsoil 2 asphalt base $\quad 5$ grey clay

3 rubble 6 lighi brown clay
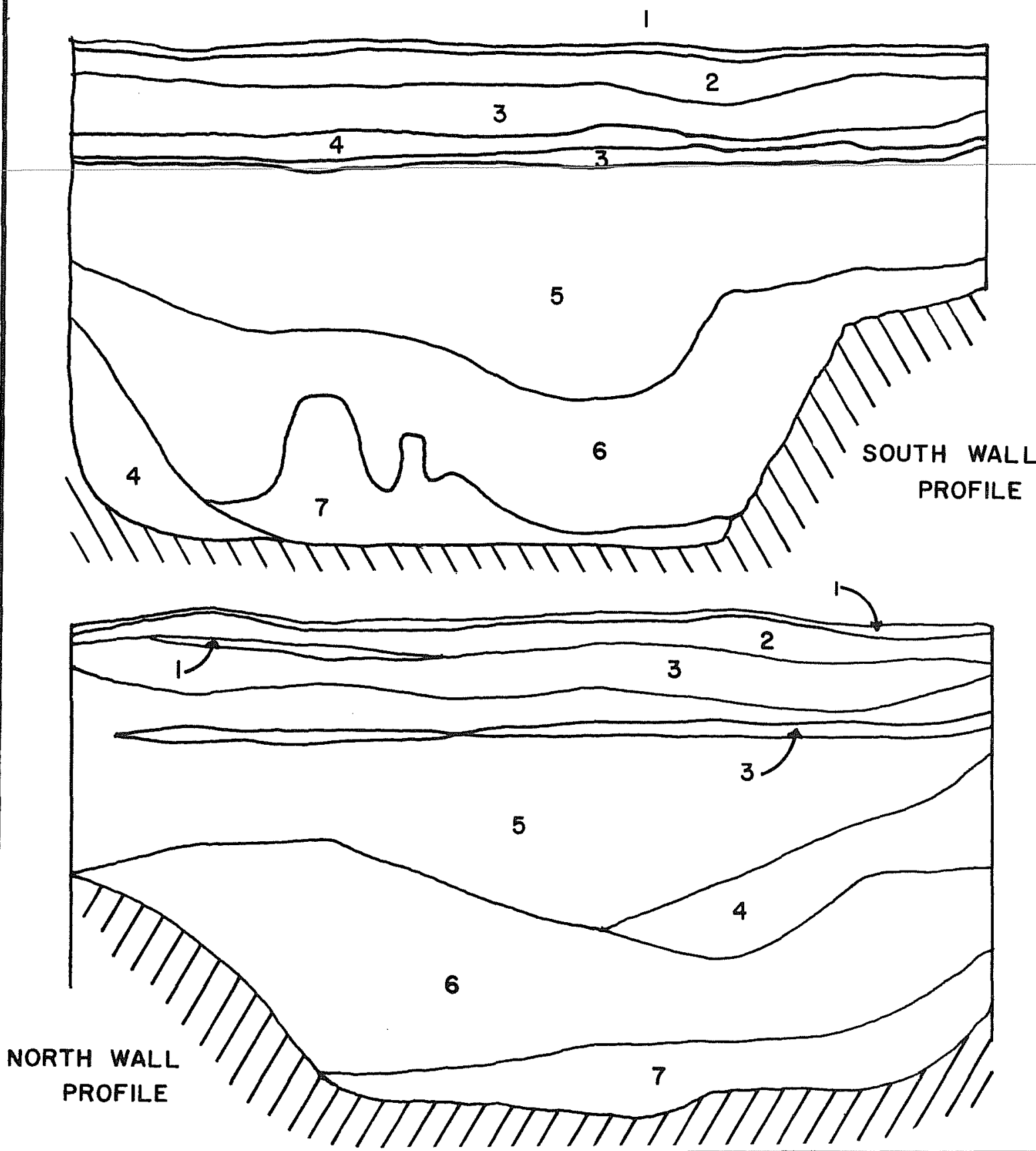

Figure 14. Profiles of Feature 6. 


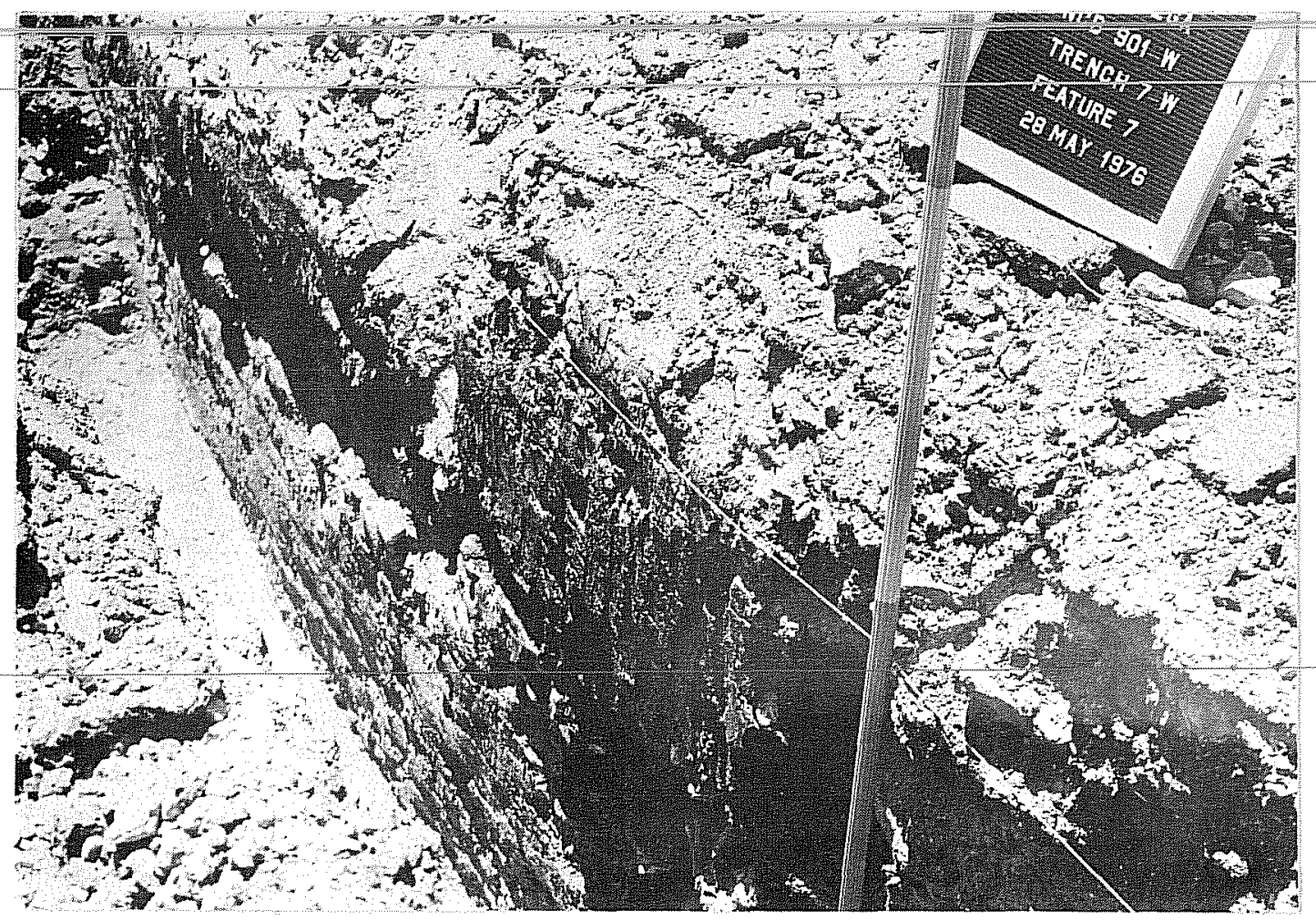

a

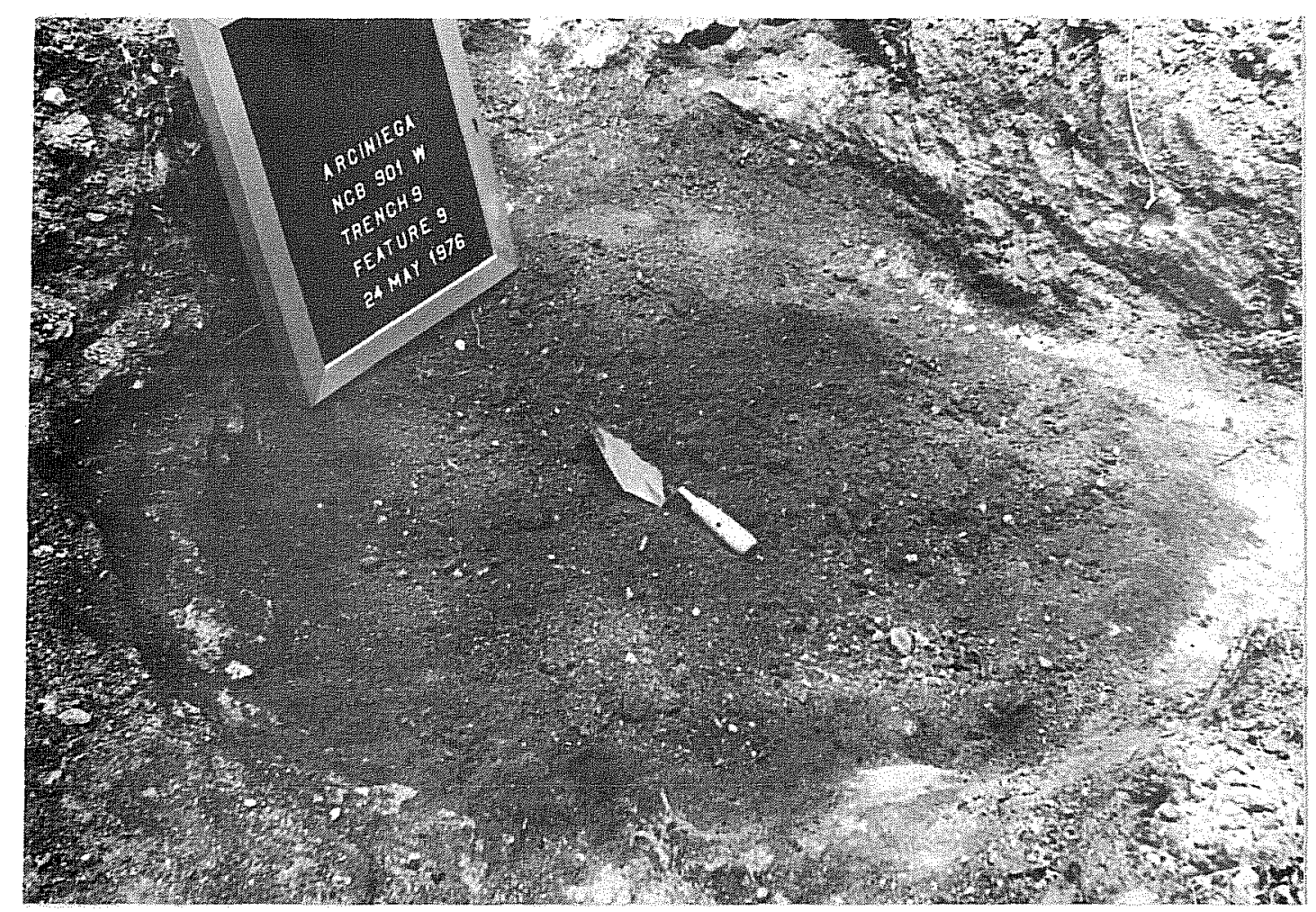

b

Figure 15. Features 7 and 9. a, Feature 7, looking southwest; feature appears in profile in the wall of Trench 7-West; b, partial excavation of Feature 9, looking northeast; excavation has proceeded to $20 \mathrm{~cm}$ below ground surface in Trench 9. 


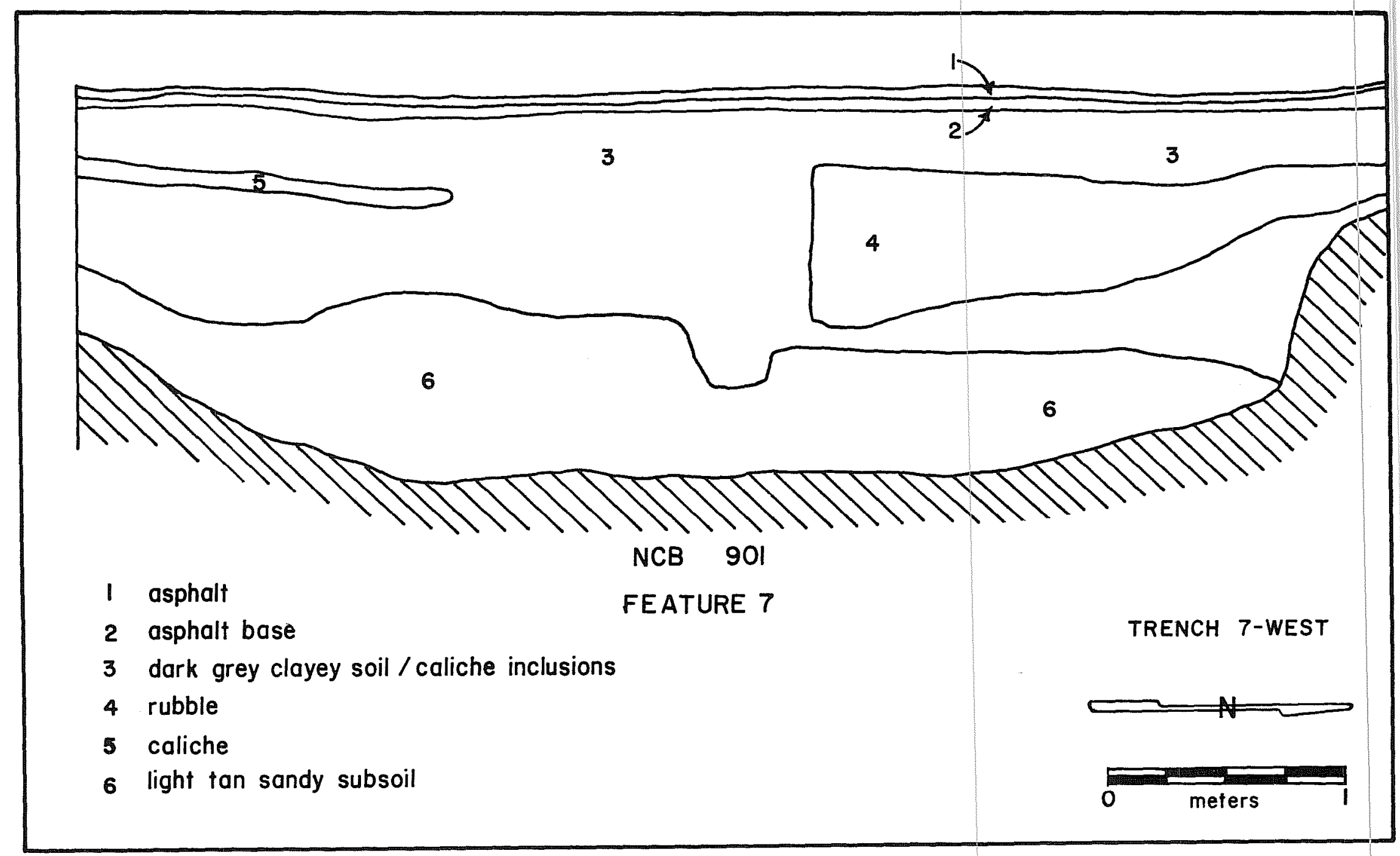

Figure 16. Profile of Feature 7. 
Feature 9

Trench 9 (Fig. 2) was cut specifically to search for a latrine pit, and one was located. The trench extended for $21 \mathrm{~m}$ in a north-south direction, across an area at the rear or side of five houses: 412, 416-418 and $422 \mathrm{~S}$. Presa, and 210 and 220 Arciniega. The feature was identified by a darker brown soil than the normal subsoil, as well as by a profusion of artifacts associated with this soil difference (Fig. 15, b). Designated Feature 9 (Fig. 11), an area $150 \mathrm{~cm}$ square was opened on the west side of Trench 9 (Trench 9-West; Fig. 2) to expose the rest of the pit.

Figure 17 provides a plan and profile drawings of the completely excavated feature. It is approximately circular at the top, measuring $120 \mathrm{~cm}$ by $110 \mathrm{~cm}$; its depth is $76 \mathrm{~cm}$. The interior contours are irregular and unsmoothed, its bottom somewhat rounded. Looking at the two profiles $(\mathrm{Fig} .17, \mathrm{~b})$, it seems to have been oriented in a north-south direction.

The artifactual material recovered from the pit fill consisted of bottles and glass fragments, ceramic fragments, construction hardware, items of personal adornment and pieces of household furnishings. The inventory parallels that of Feature 4 and $4 \mathrm{~W}$ (Table 1), discussed in the following section, as does the general dating of the material, ca. 1880-1890. This date range would be the time of filling, it is to be remembered, not the time of construction. Associated faunal material, about 300 specimens, also parallels the list for Features 4 and $4 W$ (Table 3).

In attempting to associate this feature with one of the residential structures, Fig. 1 proved helpful. This map, drawn in 1904, shows two wooden outbuildings in the general vicinity of the excavated feature, one at the rear of $416 \mathrm{~S}$. Presa (now 412) and the other on the west side of 220 Arciniega. The South Presa house was only constructed during the period of feature filling; there is the north-south orientation of the 200 Arciniega outbuilding; and this latter residence was constructed about 1850, well before the postulated filling period. Given the above, this latrine pit and its associated cultural material are considered to be associated with 220 Arciniega.

\section{Feature 12}

This Feature (Fig. 11) consists of a rectangular pit, $42 \mathrm{~cm}$ wide and of undetermined length, cut into bedrock to a depth of $82 \mathrm{~cm}$ below ground surface. It is situated in Trench 12 (Fig. 2), $5 \mathrm{~m}$ southeast of the rear portion of 220 Arciniega. Its fill was a dark brown humic soil, but neither artifactual nor faunal material was associated. Its configuration and proximity to the house suggest a function similar to Feature 5B, that is, a domestic trash pit. There is no evidence, however, that it was ever used, and at present its function remains unknown.

"Gazebo-Cistern"

One further feature bears mentioning, the cistern associated with 228 Arciniega. MacMil1an (1971:11) mentions that it appears on both the 1904 and 1924 Sanborn 


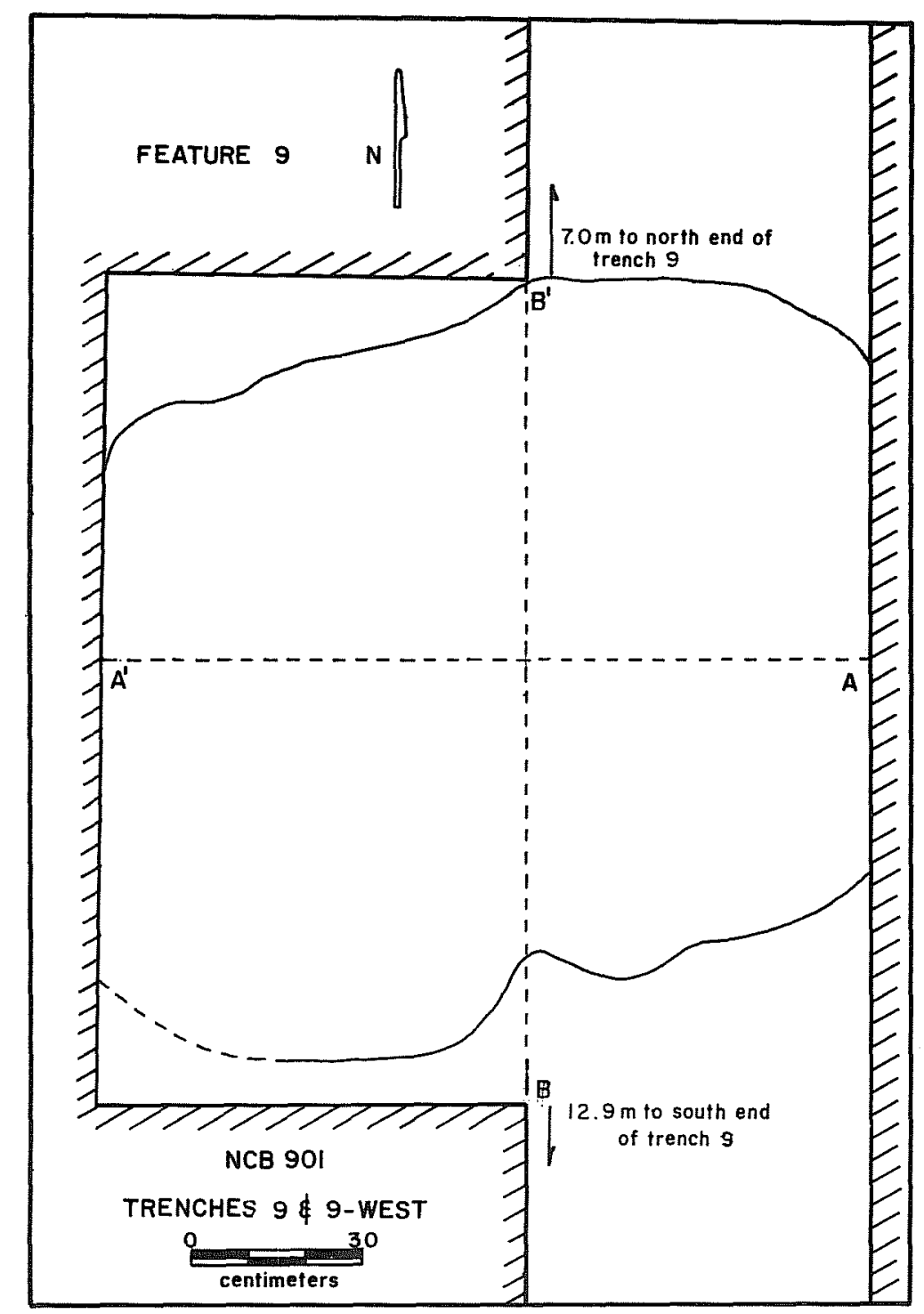

a

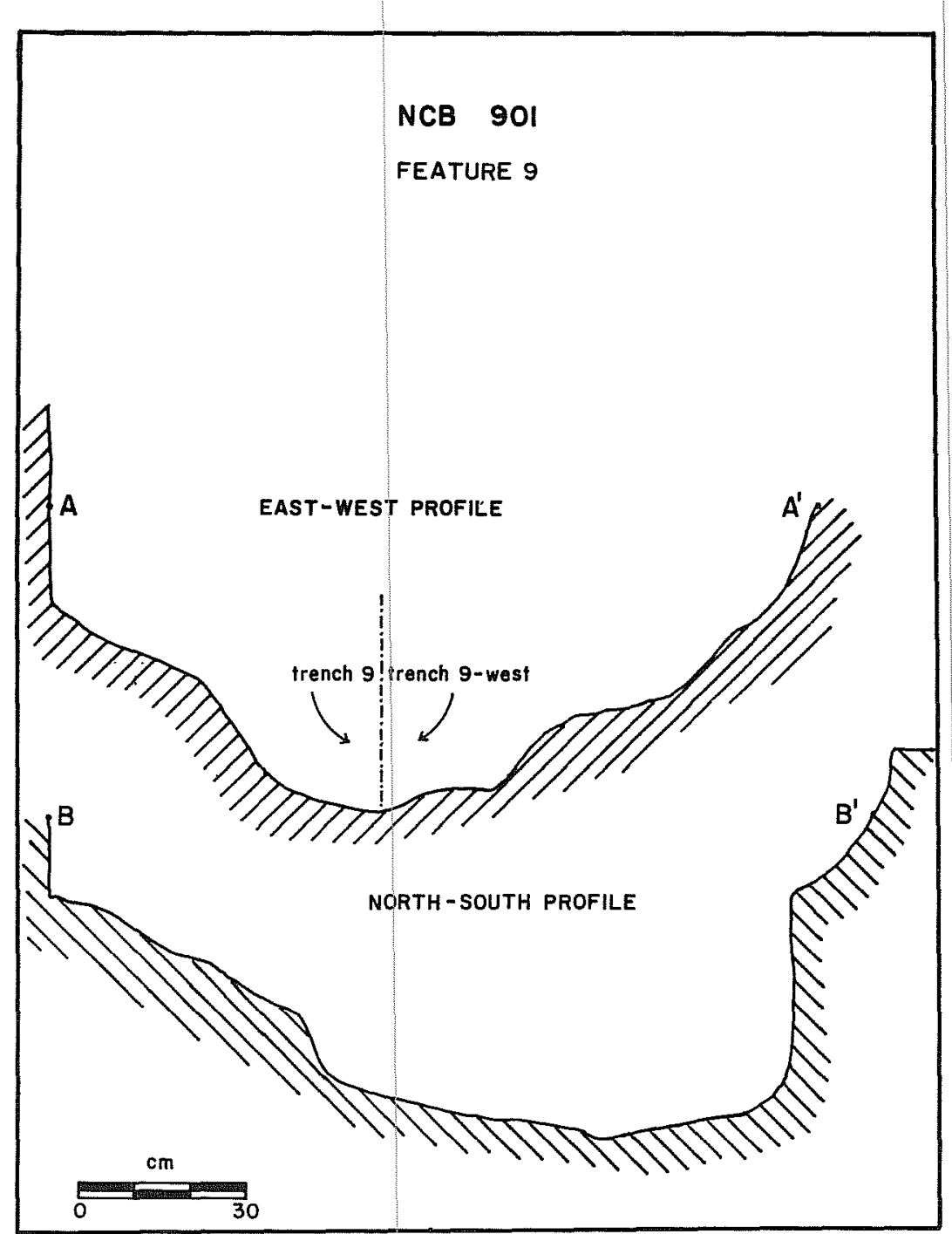

b

Figure 17. Feature 9. a, plan of Feature 9; b, profiles of Feature 9. 
Insurance Maps, and a circular structure does show on the sketches provided in her report; the finished 1904 map reproduced in the present report does not provide this information. Informants, however, continually told the field crew of this feature, specifically that it was brick-lined and full of artifactual material.

In that this cistern would be expected to have preserved a wealth of late nineteenth century domestic data, efforts were made to locate it toward the close of the field session. Following the sketches in MacMillan's report, trench systems 14 and 15 (Fig. 2) were cut across the suspected area. Despite over $40 \mathrm{~m}$ of trench, however, the feature was never located.

\section{Excavation of Features 4 and $4 W^{*}$}

These features were discovered when Trench 4 was dug through the area which was once the backyard of 224 Arciniega Street (Figs. 2,4,18,19). Quantities of bricks, broken glass and animal bone alerted the excavators that some sort of trash disposal area was present. The backhoe was stopped in order to allow careful examination of what appeared to be a large pit which had been filled with household trash. Excavation then proceeded by hand. A datum was estab1 ished on the north side of the pit (Fig. 19). The disturbed surface of the feature was carefully cleaned until the area was sufficiently cleared to reveal that the backhoe had cut between two subterranean pits of unequal size and differing construction. At this point, the features were designated 4 and $4 \mathrm{~W}$ and were excavated separately.

\section{Feature 4}

Excavation proceeded in arbitrary levels of approximately $20 \mathrm{~cm}$, while at the same time attempting to comply with depositional layers where they could be observed. A representative sample of the contents of each level was screened through 1/4-inch mesh, and a soll sample was taken from each level for more thorough examination in the laboratory. The pit measured $100 \times 140 \mathrm{~cm}$, and the bottom was found to be $235 \mathrm{~cm}$ beneath the present ground surface. It had been dug through approximately $75 \mathrm{~cm}$ of soil and then $160 \mathrm{~cm}$ of caliche bedrock, the upper section being subsequently lined in some places with roughly-shaped limestone chunks and in other places merely outlined by the soil through which it was dug. No trace of plaster lining or mortar was observed in the construction. The top of this feature was, at one time, covered with large limestone slabs, several of which were found in place. The site has subsequently accumulated approximately $50 \mathrm{~cm}$ of soil above the features.

The top $50 \mathrm{~cm}$ of the excavation, primarily removed by the backhoe operation, consisted of a heavy dark brown clay soil with a few early 20 th century artifacts. Beneath this was the above mentioned layer of limestone slabs, followed by a $20 \mathrm{~cm}$ zone of friable, light brown soil tightly packed with bricks, rocks and mortar which appeared to be building rubble. Immediately below the $70 \mathrm{~cm}$

*Prepared by Anne A. Fox 


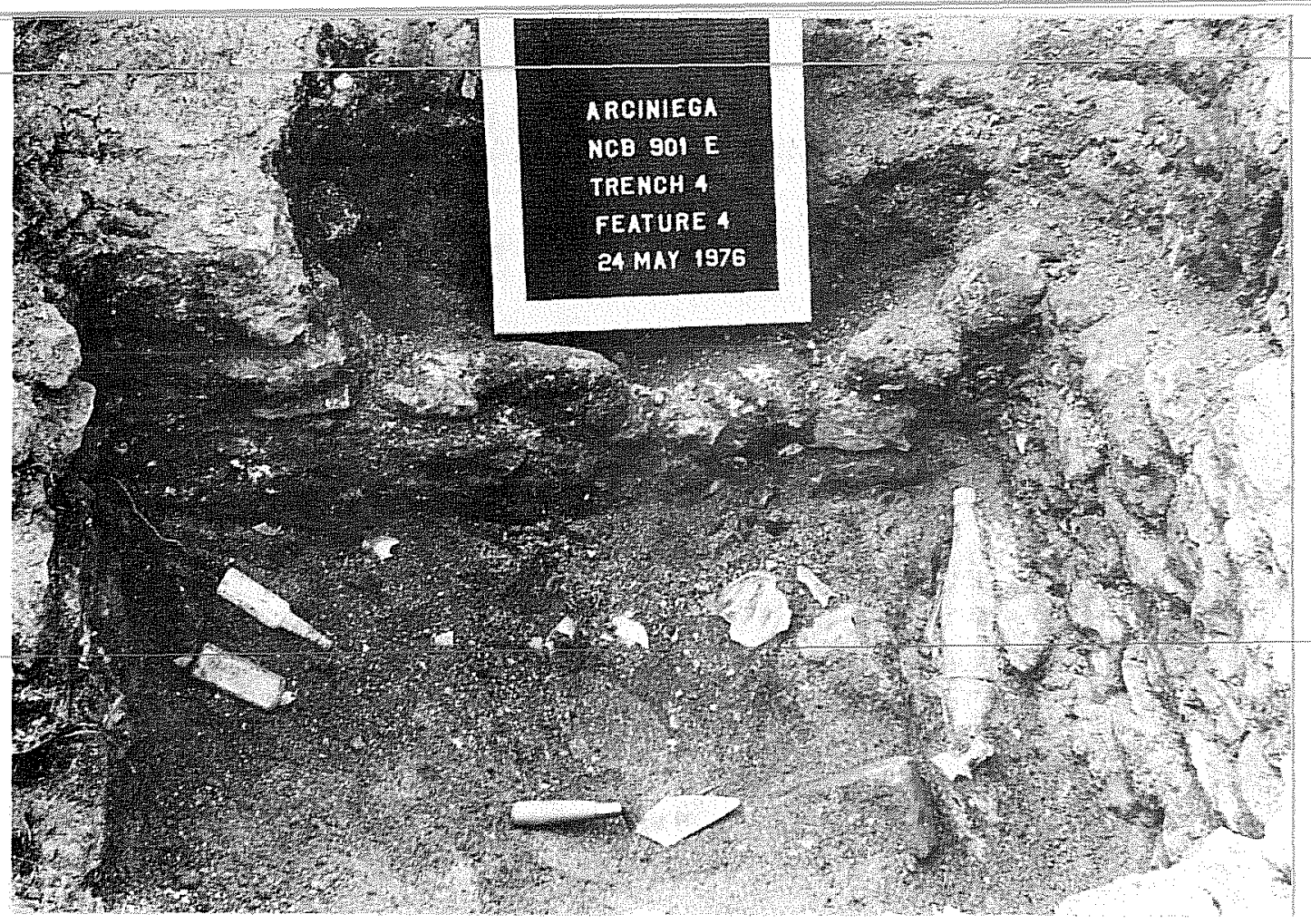

a

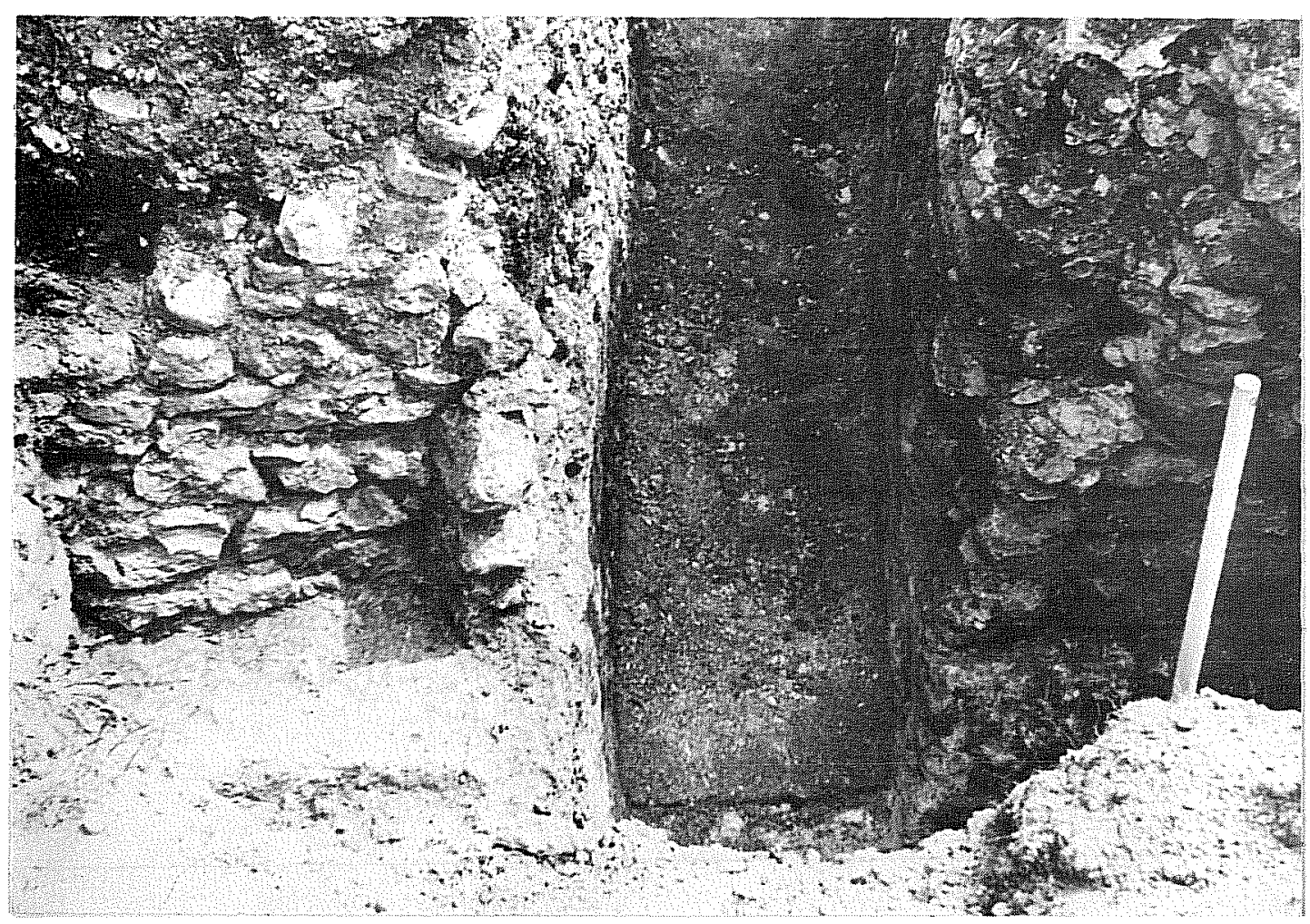

b

Figure 18. Excavations of Features 4 and $4 w$. a, partial excavation of Feature 4; looking west; excavation has proceeded to $115 \mathrm{~cm}$ below ground surface; b, completed excavation of Features 4 and $4 \mathrm{~W}$, looking north; at the south end of Trench 4, which was deepened at this end to facilitate excavation of the features. 

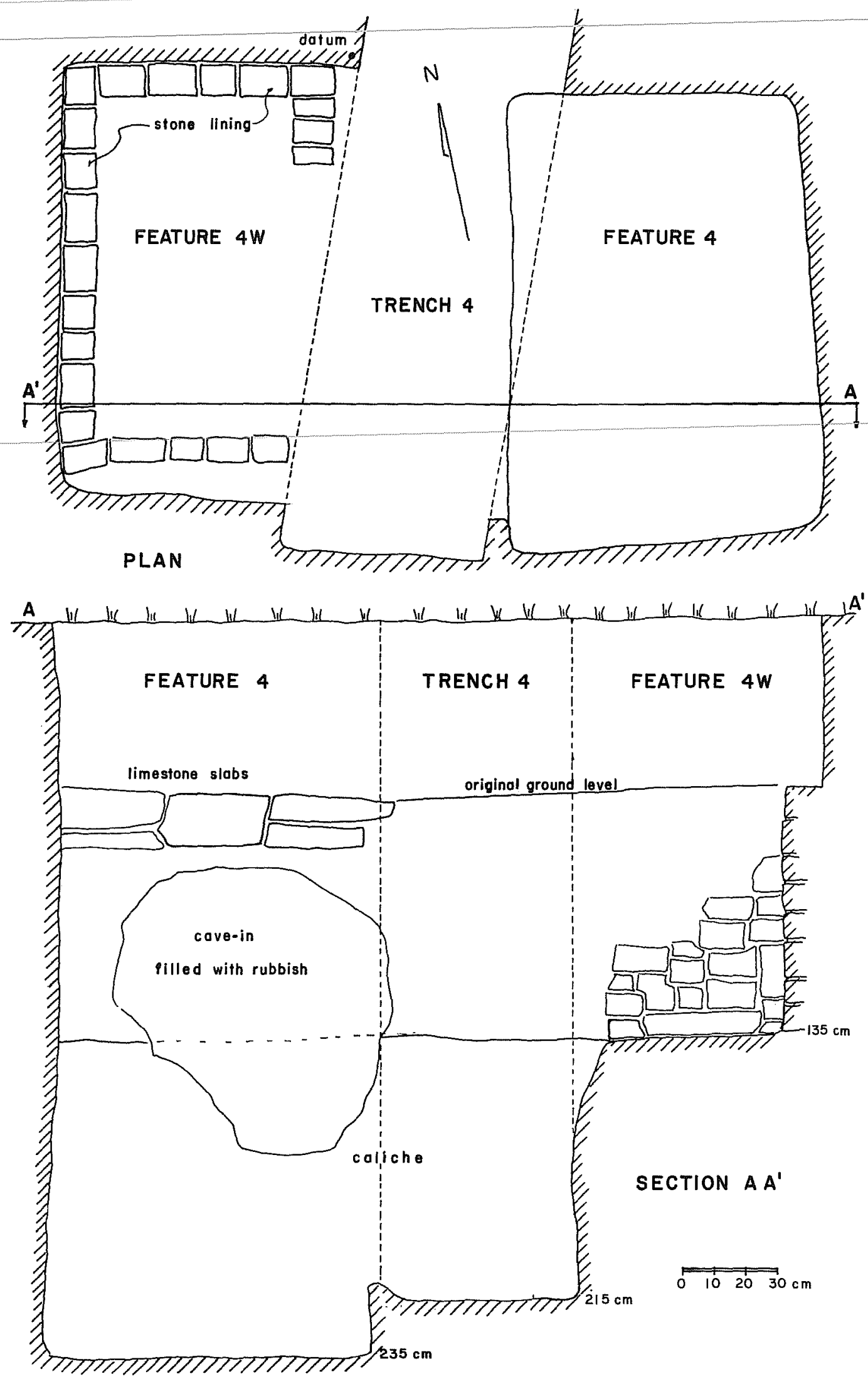

Figure 19. Plan and Profile of Features 4 and $4 \omega$. 
level began a loose fill of brownish soil and artifacts (Fig. 18,a) which continued without much noticeable stratification to the bottom of the pit, although the fill became more compact toward the lower levels. Large areas of ash and charcoal seemed to represent discrete loads deposited in the pit. Nearly all the fish bones were found against the east wall, and it appeared that most of the dumping of trash may have been done from that side. A rusted mass of over 100 snuff cans was found on the east side between the $195 \mathrm{~cm}$ level and the bottom. The lowest level, from 230 to $235 \mathrm{~cm}$, was made up of a crumbling mineralized substance, in which was found a number of whole bottles and many more snuff cans.

\section{Feature 4W}

Feature 4W was found to be a carefully constructed stone-lined pit approximately $70 \times 140 \mathrm{~cm}$ in size which had been dug until bedrock was encountered at $135 \mathrm{~cm}$ below the original surface (Figs. $18, \mathrm{~b} ; 19$ ). The feature was excavated in arbitrary levels, as no stratification could be observed. The contents were periodically screened for maximum recovery of small artifacts. The fill appeared to be uniform and the content similar from top to bottom; both fill and content were similar to that in Feature 4, although no cross-matching was found between the artifacts.

The Artifacts

A general listing of the types of artifacts recovered appears in Table 1, and selected objects are illustrated in Figs. 20 to 35 . The volume and variety of artifactual material present in the two features were a great deal more than had been anticipated when planning the project. Time has allowed only a cursory study of those items which would aid in dating the features. All the materials have been preserved and catalogued, ready for more detailed analysis at a future date.

\section{Interpretation and Dating}

The backhoe had completely removed all trace of the area between the two features, and it was not determined how, or indeed if, they were related. The fact that they were both oriented in the same manner and located so close together seems to imply that they were, however.

The original use of the pits has not been positively determined. Feature 4 would appear from its size to have been a cistern, but without some sort of lining on the upper part, it would never have been over half full. Apparently water stood in the bottom of the pit over a long time, to judge from the mineral deposit present in the bottom layer. The badly rusted condition of the metal artifacts in the lowest levels indicates that it was partially full of water when the trash dumping was begun. It appears that the trash was deposited in the pit on a regular basis over a period of time. In order to determine the time period involved, certain classes of datable artifacts were isolated and studied in detail. 


\section{TABLE 1. TYPES OF ARTIFACTS RECOVERED FROM FEATURES 4 AND $4 \mathrm{~W}$}

\section{Food Preparation, Serving and Storage}

white, undecorated porcelain gold decorated porcelain painted porcelain plain white earthenware transfer-printed earthenware sponged and spattered earthenware banded earthenware she11-edged earthenware hand-painted earthenware flown blue earthenware gold-on-white earthenware ironstone

flint-enameled ware decal-decorated earthenware stoneware

bisque

cast iron stove fragments ceramic charcoal stove pan handles knives spoons enameled dishpan bottle opener clear food, medicine and beverage bottles amber beverage bottles olive green wine bottles "black glass" wine bottles blue medicine bottles light green beverage bottles aqua food, beverage and medicine bottles white medicine and ointment jars canning jars and liners tumblers goblets pressed glass pitchers and bowls

tin cans bottle tops jar lids

animal bone egg she11 mussel shell

\section{Hardware and Furniture}

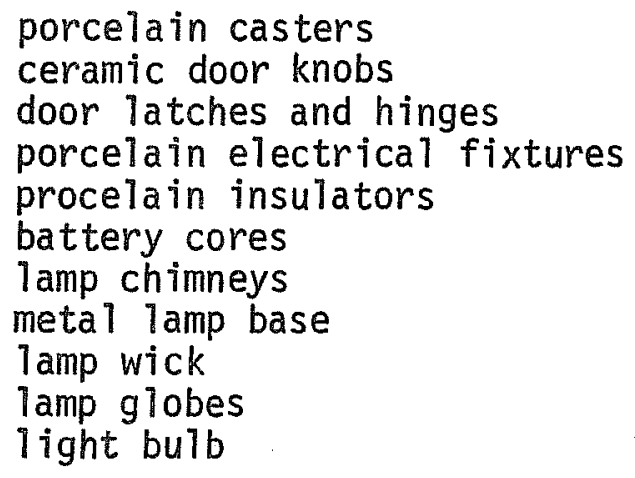

hatchet head

wrench

file

cold chisel

horse shoes

harness buckles

snap hook wire nails

cut nails

screws

staples

bolts

tacks

washers

hooks copper wire brackets 
TABLE 1. (continued)

\section{Personal and Miscellaneous}

buckles

buttons

shoe eyelets

shirt studs

collar buttons

beads

safety pins

straight pins

hat pins

locket scissors

composition combs

hand mirror

bone tooth brush handles

stocking suspenders

shoe fragments

celluloid collars

umbrellas

doll parts

folding ruler pipe stem

coins

clock parts

shotgun shells

bicycle tire fragments

slate pencils and slate

fragments

pencil leads

advertising tokens

coal

charcoal 
One of the most helpful objects for dating historic sites is the familiar drug store bottle of the late 19th century. At this time, druggists and soda water bottlers generally had the name of their firm and its address embossed on their bottles (Fig. 31). A compilation of such bottle labels using the known dates of initiation and dissolution of firms, which can be obtained from city business directories, produces a time frame within which the deposit was probabiy accumulated (Table 2). The only problem is the unknown length of time which such bottles could have 1 ingered in a household before being discarded, which makes the date of last deposit rather vague. In this case, Features 4 and $4 \mathrm{~W}$ appear to have been filled after 1899, when the Mission Drug Store opened (one Mission bottle was found at $230 \mathrm{~cm}$ ), and filling probably ceased sometime not too long after 1905, when James Clavin went out of business. This is reinforced by the face that Ochs \& Aschbacher went out of the bottling business in 1901 . A token from the Central Dairy, run by Alex Uhl from the late 1870s to 1896 (Appler 1879 and 1896), and one from Stower's Furniture Company, which began in 1889 (Woolford 1963:159), support the proposed dates.

The suggestion that Feature 4 was used as a cistern gains credibility when one considers the possibility that Feature $4 \mathrm{~W}$ was built in connection with it as a cooling chamber for perishable foods, utilizing the cool, moist atmosphere. It is difficult to tell when and in connection with which structure the pits were originally built, since no artifacts found in the bottom of Feature 4 appear to pre-date the general body of the trash deposit. However, looking at the map of the area as it was in 1904 (Fig. 1), it seems likely that the cistern may have been constructed originally in conjunction with, and filled from the roof of, the adobe portion of the house at 228 Arciniega at a time before the 224 Arciniega house was built. This would imply that perhaps the smaller cooling pit, if such it was, could have been a later addition by the inhabitants of 224 Arciniega when they established the property line and acquired that part of the site. Evidentiy they built some sort of a shed over the feature, and then eventually used it as a trash disposal pit when they no longer needed it for its original purpose. It would be interesting to know if there was a door on the east wall of that shed, causing the deposition to have been made from that side.

Some interesting insight into the food habits of the family whose trash filled the features can be gained from the list of animal bones recovered from the deposit (Table 3). Obviously the man of the house was a fisherman and may also have been a dove hunter, judging from the number of small bird bones present. Chicken was apparently readily available, probably being raised in the back yard. The number of sawed bones suggests that beef was more utilized than the identified bones indicate. This is probably a result of the methods used in butchering and cooking which would make the fragments unidentifiable. Rats were apparently a problem in the city at that time, as the same species still plagues us today, according to local authorities (Interview, Mary McLennon, Rat Control Division, Fish \& Wildiffe Department, City of San Antonio).

These minimal interpretations are but a sample of the information contained in this "time capsule" from late 19th century San Antonio. The collection from this excavation warrants more detailed study and analys is in the near future. 
Table 2

\section{DATABLE BOTTLES FROM FEATURES 4 and $4 W$}

\section{Druggists}

Adolph Dreiss

F. Kalteyer \& Son

J. Calvin

C. Schasse, 15 Commerce

Yarbrough \& Giles

Wm. Appmann

Kalteyer \& Schuchard

Mission Drug

\section{Bottlers}

\section{Duerler}

Esser

Ochs \& Aschbacher

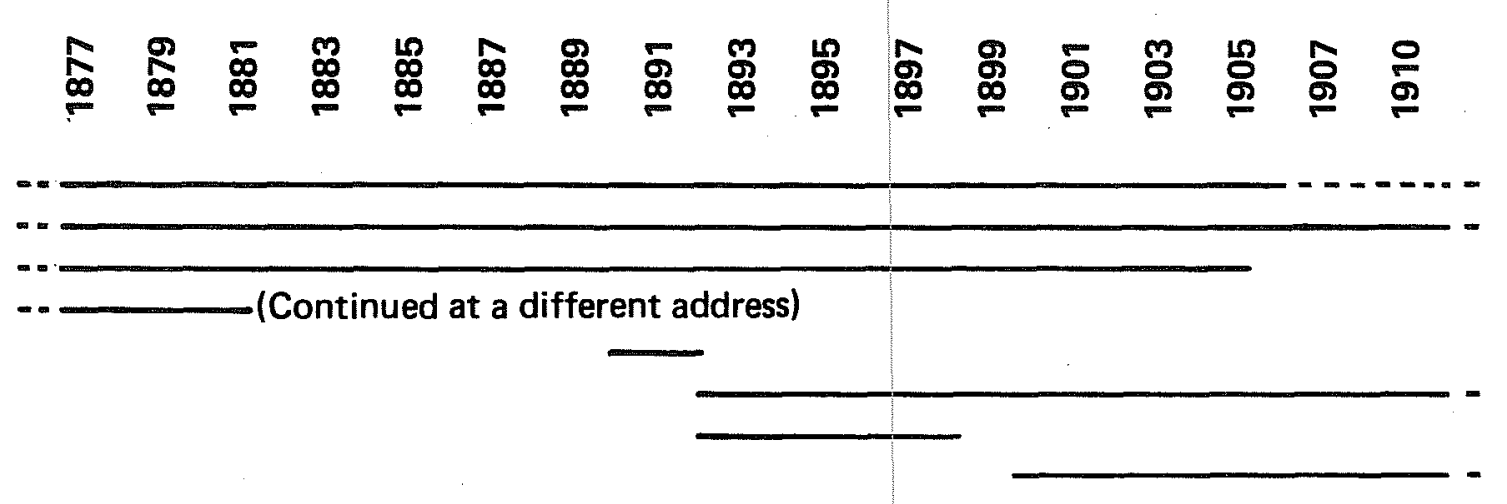

Sources: Mooney and Morrison 1877 Morrison and Fourmy 1879-1889

Johnson and Chapman 1891

Jules A. Appler 1892-1910 
TABLE 3. FAUNAL REMAINS FROM FEATURES 4 AND $4 W$

Species

Unidentified crayfish

Unidentified fish

Lepomis sp. (sunfish)

Lepomis cyanellus (green sunfish)

Lepomis microphus (redear sunfish)

Micropterus salmoides (black bass)

Ictalurus sp. (catfish)

Ictalurus funcatus (blue catfish)

Pylodictis olivaris (yellow catfish)

Aplodinotus grunniens (freshwater drum)

Rana sp. (frog)

Rana catesberana (bullfrog)

Unidentified turtie

Pseudemys sp. (slider turtle)

Unidentified bird, small

Gallus gallus (domestic chicken)

Meleagris gallopavo (wild turkey)

Colinus virginianus (bobwhite)

Zenaidura macroura (mourning dove)

Mimus polyglottis (mockingbird)

Richmondina cardinialis (cardinal)

Mephitis mephitis (striped skunk)

Mus musculus (house mouse)

Rattus norvegicus (Norway rat)

Lepus californicus (blacktail jackrabbit)

Sylvilagus sp. (cottontai 7 )

Sylvilagus floridanus (eastern cottontaii)

Sus scrofa (domestic pig)

Capra Sp. (domestic goat)

odocoileus virginianus (whitetail deer)

Bovid (cow or bison)

Unidentified fragments

Sawed bones
Number of

Fragments

3

2560

4

22

2

32

54

13

15

2

1

3

322

32

252

1

3

6

8

1

16

325

1

63

1

1

5

2

12

2990

401

TOTAL

7170 
Comparisons of these materials with those obtained from other excavations in downtown sites will add greatly to our understanding of life in San Antonio at the turn of the century.

Sources used for the analysis and dating of recovered artifacts include: Appler (1892-1909), Barber (1904), Godden (1964), Johnson and Chapman (1891), Mooney and Morrison (1877), Morrison and Fourmy (1879-1889), Polk (1884) and Texas Publishing Company (1910). 
Figure 20. Selected Artifacts from Features 4 and 4w: Ceramic Sherds. $a$, blue and white banded pearlware, pitcher or mug; $b$, blue, green and black on white hand-painted pearlware, cup; c, flown blue pearlware with repousse design, cup; $d$, blue and copper luster on red stoneware body, pitcher; e, gold decorated white earthenware, plate; $f$, aqua transfer on white earthenware, butter chip; g, blue glazed molded utility ware with white interior, plate or bowl base; $h$, purple sponged decoration on heavy ironstone, plate; $i$, yellow spattered pearlware, pitcher or teapot; $j$, lead glazed redware bowl with brown design; $k$, lead glazed redware molcajete with incised bands. 


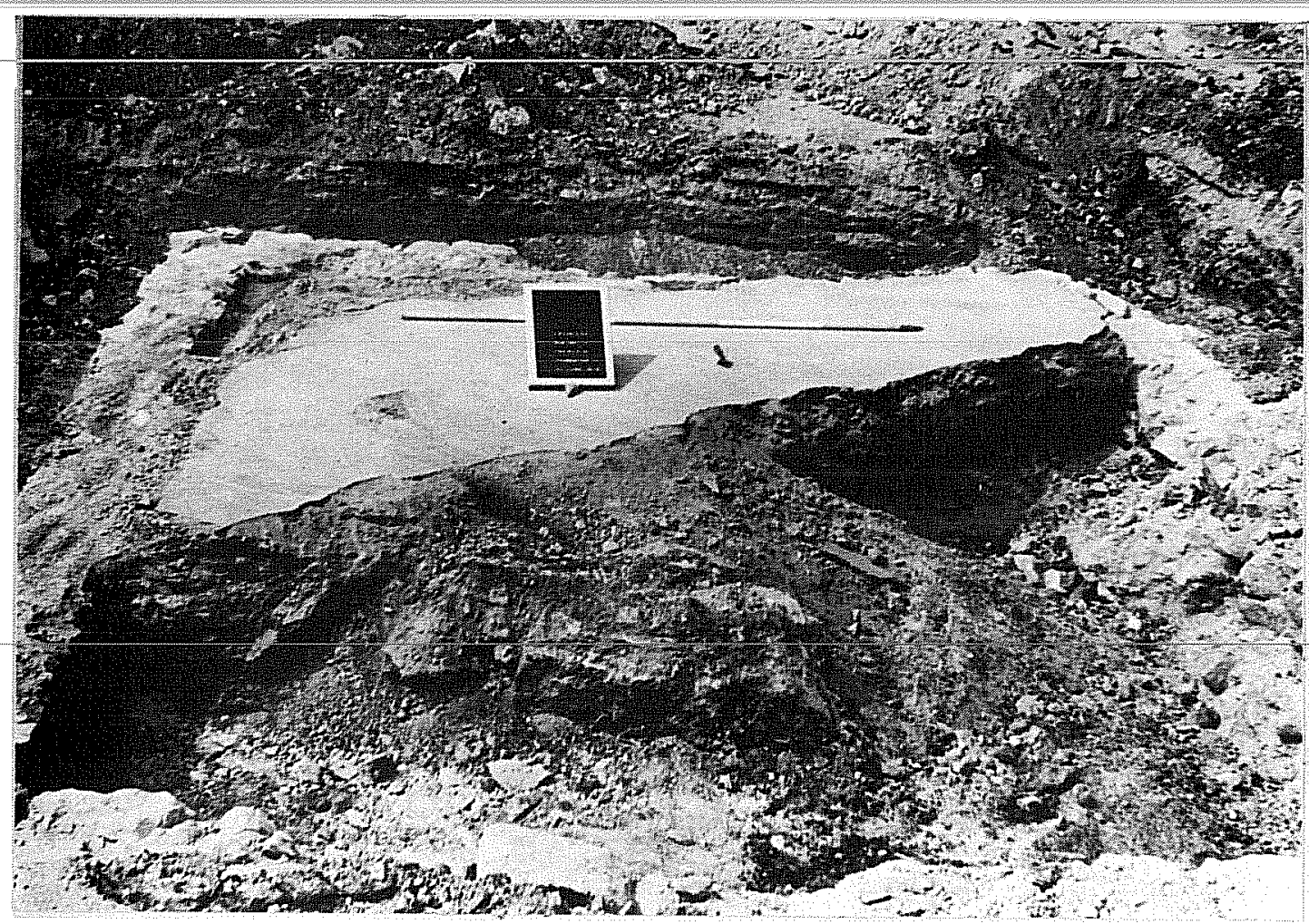

a

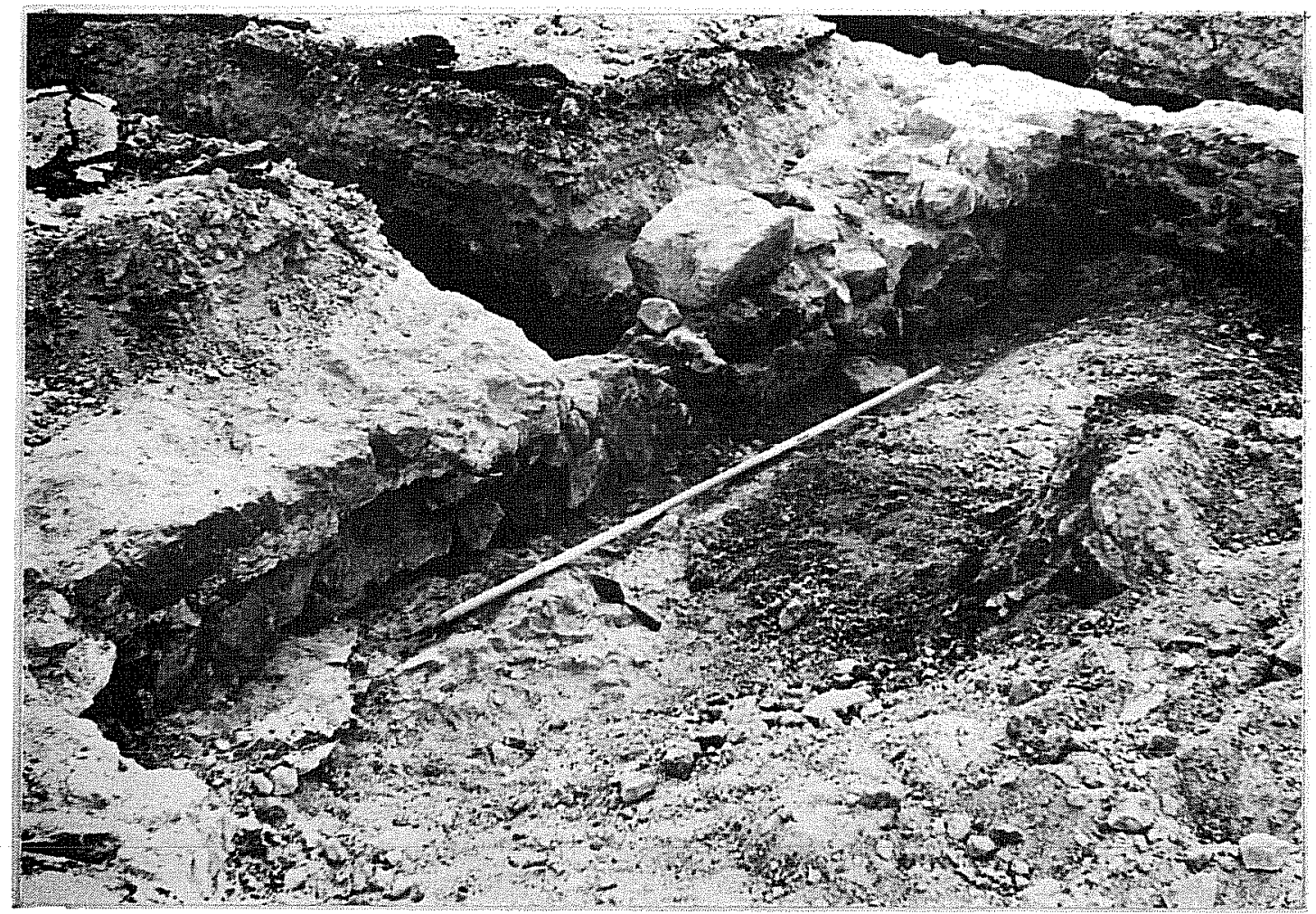

b

Figure 9. Foundation XII (228 Arciniega). a, south room, looking south; a remnant of the parking lot asphalt surface shows within the periphery of the room's foundation; b, north wall of south room, looking northeast; Trench 13South extends north into the south-central room in this north-south series of four rooms at the rear of 228 Arciniega. 


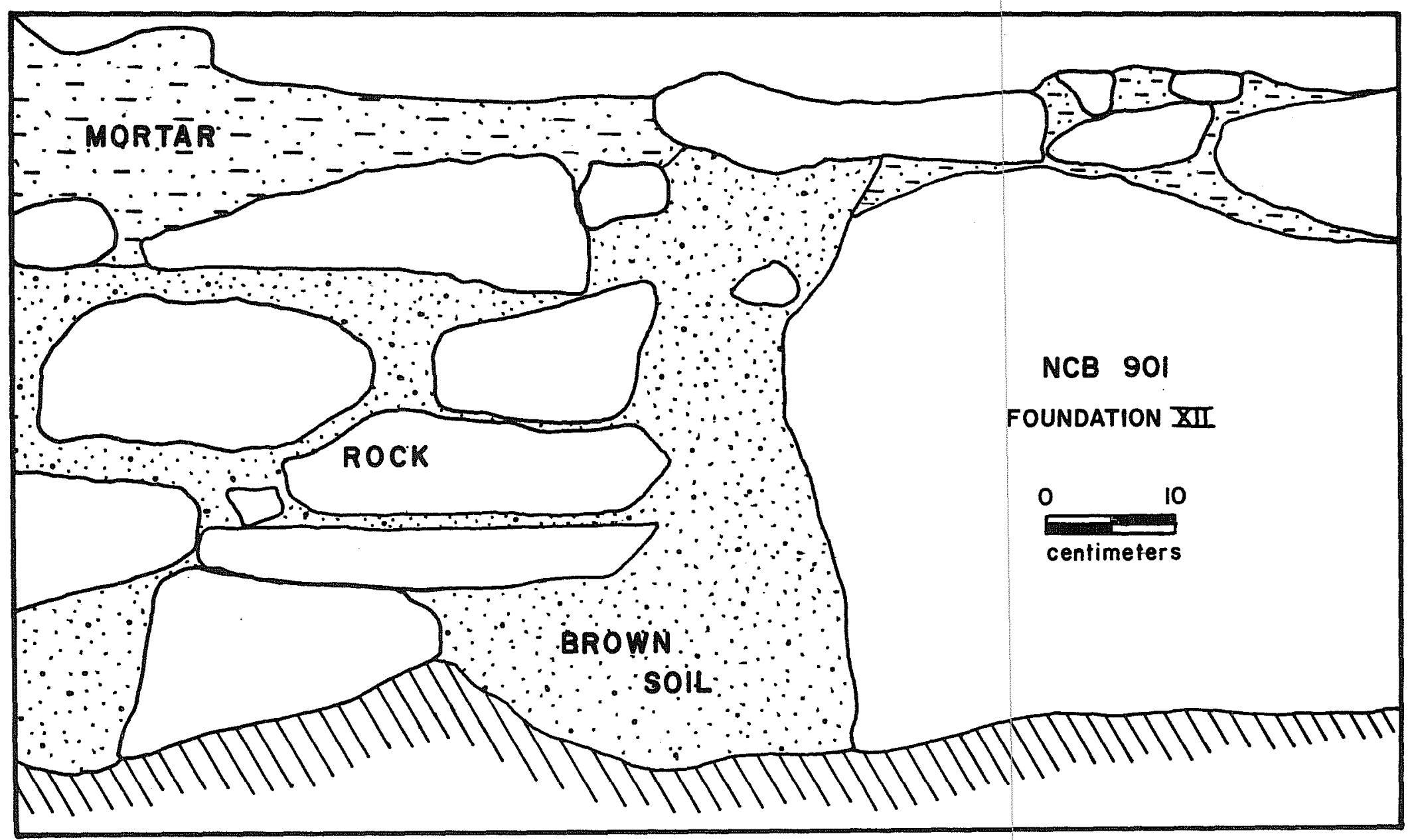

Figure 10. Profile of a Portion of Foundation XII (228 Arciniega). The profile is drawn of the exterior face, at a point near the northeast corner of the south room. 
subsequent disintegration. Mortar does remain as a capping for the foundation along every side of the room. Some foundation stones bore grooves cut vertically into the stone, possibly to hold wooden pegs. The foundation rests on bedrock, :approximately $50 \mathrm{~cm}(1.6 \mathrm{ft})$ below the top of the foundation wall.

Artifactual material associated with Foundation XII was almost non-existent; the few that were recovered were not good chronological indicators. In one sense, nothing was noted or recovered which would suggest the back four rooms were not earlier than the front portions, as the various researchers have suggested. On the other hand, there is nothing which argues against contemporaneity and one fact in its favor: structurally, the rear room foundation walls show no differences from the front portion foundation, the latter fairly definitely dated to the early 1840s.

Two cultural features are also associated with 228 Arciniega, the cistern (Feature 4) to the southwest and a trash pit (Feature 5B) to the east (Fig. 11). As has been mentioned previously, the artifacts in the cistern date its filling rather than its construction; in this case it was filled much later than either portion of 228 Arciniega was supposed to have been built. The same filling constraint pertains to the dating of the trash pit, although in this case evidence points to the period of the 1850s. Both features will be considered in more detail in subsequent sections; the point to make here is that the contents of neither can be employed to push the construction date of the rear portion beyond the 1841-42 construction date of the front portion.

\section{Arciniega (Adler House)}

At the time of archaeological investigations in 1976, this house was in the final stages of demolition. Although within the boundary of the proposed hotel, its twentieth century construction date and visible foundation precluded the necessity of investigation. Background is provided by MacMillan (1971:12):

The house was built in the fall of 1912 by Emil Niggli for Joseph $S$. and Rosa Hahn. The architect who designed the house was Ernest Behles. The brick house was laid on a solid rock foundation and has outer walls three feet thick. The flooring is edge-grained pine. The living room has a brick fireplace.

Benjamin and Tillye Adler were the last residents. Benjamin came from Des Moines, Iowa in 1906; Tillye is a daughter of the Hahns.

This is one of the 27 "significant" buildings in the La Villita Historic District, and it is the fourth and final one considered thus far to have been situated on NCB 901. The National Register of Historic Places inventory nomination form (Be11, Hume and Williamson 1971) states the following:

26. House at the corner of Arciniega and South Alamo streets. Circa 1900, two-story brick structure, not outstanding.

Given that it was eventually demolished in 1976, one suspects that its most "significant" aspect was the fact that it was still standing on NCB 901 at the time the La Villita Historic District was nominated to the National Register of Historic Places. 


\section{South Alamo Street (NCB 901)}

\section{1-505 S. Alamo (Geyer Ice Cream Company)}

Trench 8 (Fig. 2), extending $15 \mathrm{~m}$ in a northeast-southwest direction, was cut at the corner of Arciniega and S. Alamo to investigate the vicinity of the proposed hotel's northeastern foundation pier. Several broken slabs of concrete foundation (designated $\mathrm{X} ; \mathrm{Fig} .4$ ) and twentieth century artifacts and building materials were noted.

MacMillan (1971:12) again provides the early history of this corner:

The lot on the corner of Arciniega and South Alamo, namely (now) 501505 South Alamo, housed an adobe store with basement, named "General Fancy and Staple Foods." This was owned and operated by Joseph and Rosie Hahn. The land was purchased by Bodowsky; Theresa Bodowsky sold it to Otto Staffel May 29, 1906.

More recently, however, this corner was the home of the Geyer Ice Cream Company. The Sanborn Insurance Map of 1924 indicates that this company maintained addresses corresponding to 234 and 242 Arciniega, as well as 501 and 505 S. Alamo. Its relatively long tenure at this location and sizable physical plant made it something of a landmark in the area.

\section{S. Alamo}

Trench 6 (Fig. 2), extending $11.25 \mathrm{~m}$ northwest-southeast, was cut for reasons comparable to Trench 8 , that is, to investigate an area where a hotel corner pier might be situated. Only bedrock (designated Foundation VII; Fig. 4) was encountered on the floor of the trench; artifactual material consisted of nails and horseshoe fragments. The structural history of this lot was not researched during the course of investigations. City directories consulted at random indicate that this portion of the block catered to auto supply and tire stores, and it can be assumed that $509 \mathrm{~S}$. Alamo was a commercial establishment for most, if not all, of its structural life.

More intriguing was the profile of a presumed irrigation ditch in the walls of Trench 6, to be discussed in detail in the following section. 
FEATURES

Extra-Domiciliary Features of NCB 901

This section is intended to provide brief descriptions of various non-structural cultural features encountered during the archaeological field work. Most of these have been mentioned previously, in connection with their association with a particular domicile or as they pertained to historical reconstruction of a specific lot. Unlike trenches and foundations, which were numbered consecutively as they were encountered, these features were assigned an integer designation corresponding to the trench in which they were identified; multiple features in a trench were usually distinguished by letter suffixes, assigned in order of discovery. Figure 11 provides the location of features to be discussed.

Feature $5 \mathrm{~A}$

Trench 5 (Fig. 2) was located somewhat arbitrarily in the central portion of the proposed hote1, oriented north-south and extending $17.75 \mathrm{~m}$. Bedrock was encountered at the south end, provisionally designated Foundation VI (Fig. 4). Much more interesting at this south end was the profile of the trench wail. The normal stratigraphy of the site is asphalt, asphalt base, demolition rubble, a gray clayey subsoil, and finally limestone bedrock. In this part of Trench 5, however, an area of gray sandy soil intruded into the gray clayey soil, measuring $116 \mathrm{~cm}$ wide and $50 \mathrm{~cm}$ deep; below this was a larger area of light tan sandy soil, extending $75 \mathrm{~cm}$ below the gray sandy soil and up to $150 \mathrm{~cm}$ beyond it on each side. The shape of the upper gray intrusion was rectangular, the lower light tan soil basin-shaped. This was designated Feature 5A, and Trench 5-South was cut to expose more of it. A section of sewer pipe was then encountered, which seemed to explain the feature as a former trench into which the pipe had been laid. While the disparity in size between the small pipe and the rather wide and deep trench was disturbing, it was not until two similar features ( 6 and 7) were uncovered that a better interpretation could be offered. It is postulated now that Feature $5 \mathrm{~A}$ represents the former channel of an irrigation ditch, conceivably dating as early as the early nineteenth century when Vicenti Micheli utilized most of NCB 901 for agricultural purposes.

\section{Feature 5B}

This feature was also first noted in the wall of Trench 5, and Trench 5-North (Fig. 2) was cut to expose more of it. It is interpreted as a domestic trash pit, most likely associated with the Micheli House at 228 Arciniega. Half the pit was unfortunately destroyed by Trench 5, and another quarter was left undisturbed when Trench 5-North was cut; Fig. 12, a shows the completed excavation of the southeast quadrant, with Fig. 13 providing a plan and profile drawings.

The reconstructed dimensions of the pit are $158 \mathrm{~cm}$ wide and $60 \mathrm{~cm}$ deep, its top located about $82 \mathrm{~cm}$ below the asphalt. It is circular in form, with straight walls and a flat bottom. A brown sandy soil characterizes the pit fill, surrounded by a lighter tan sandy soil; both intrude into the gray clayey natural subsoil. 


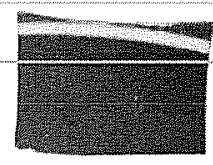

a

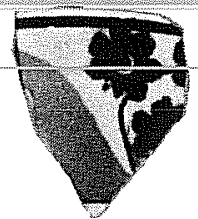

b

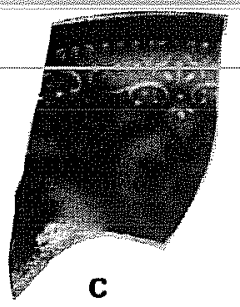

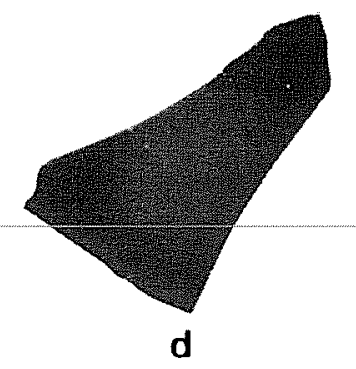
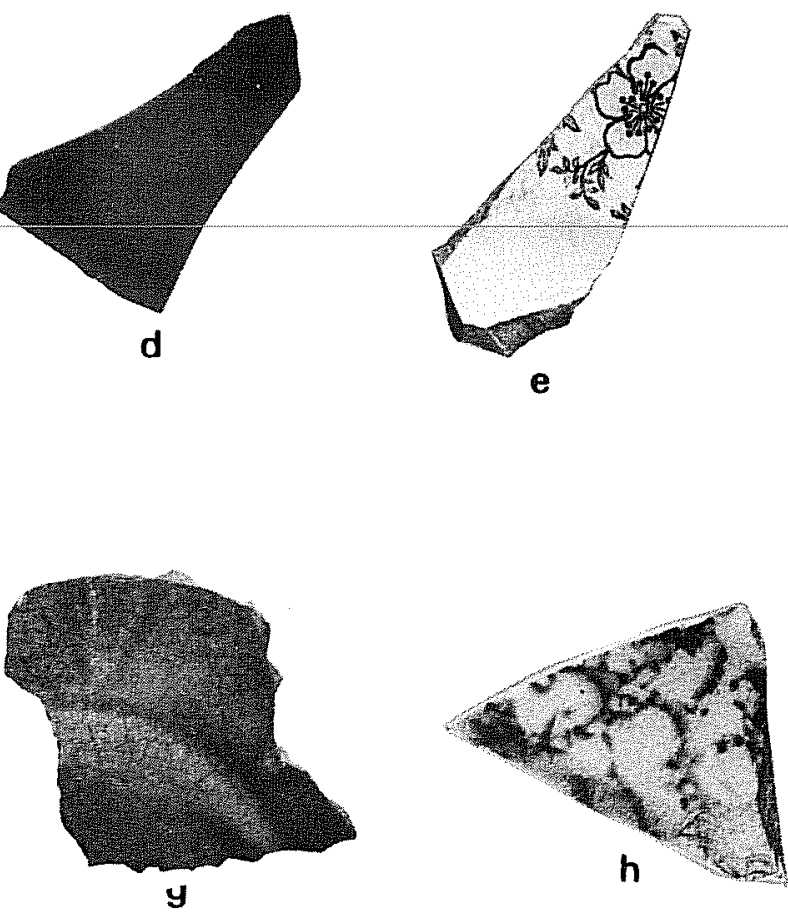
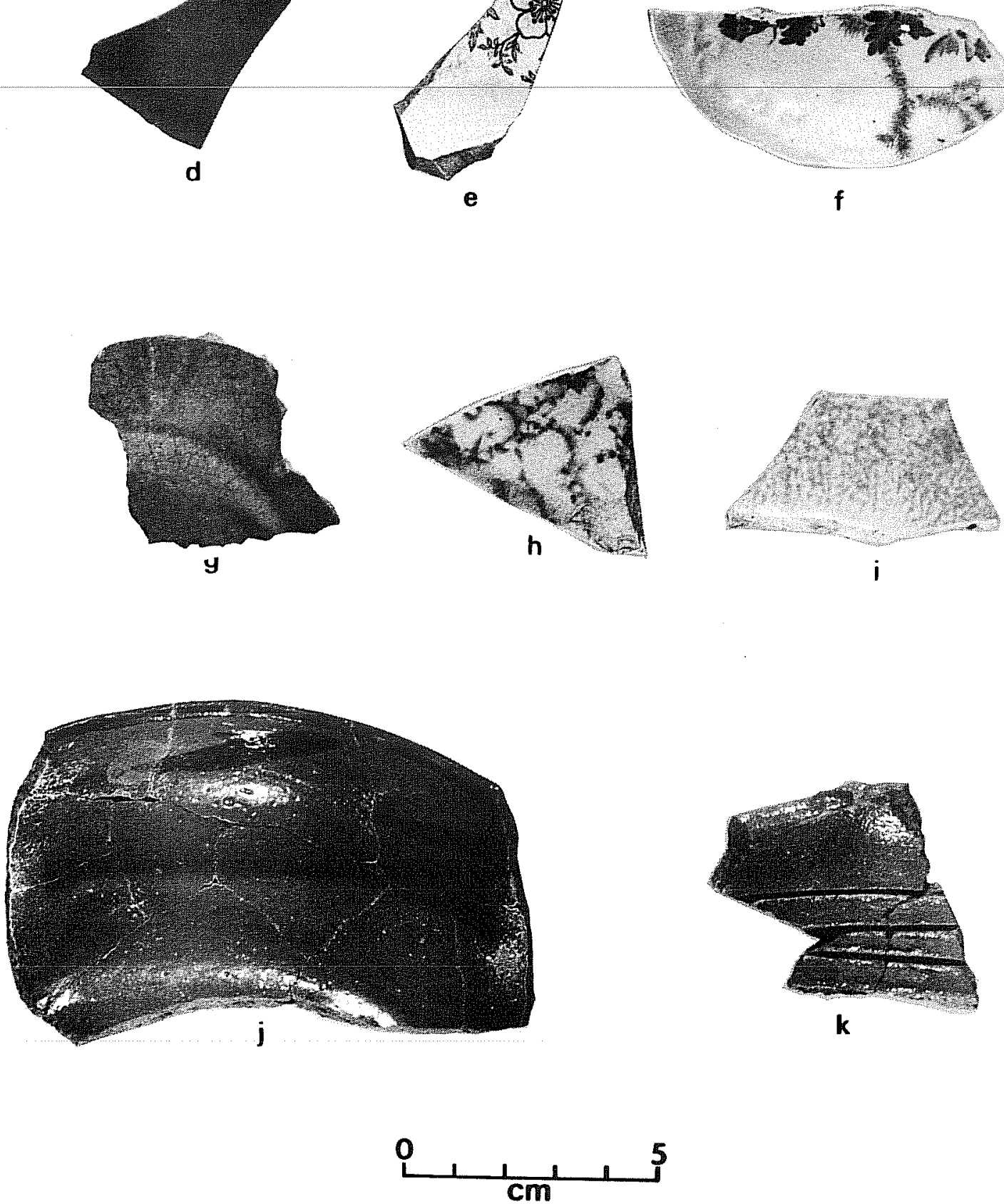

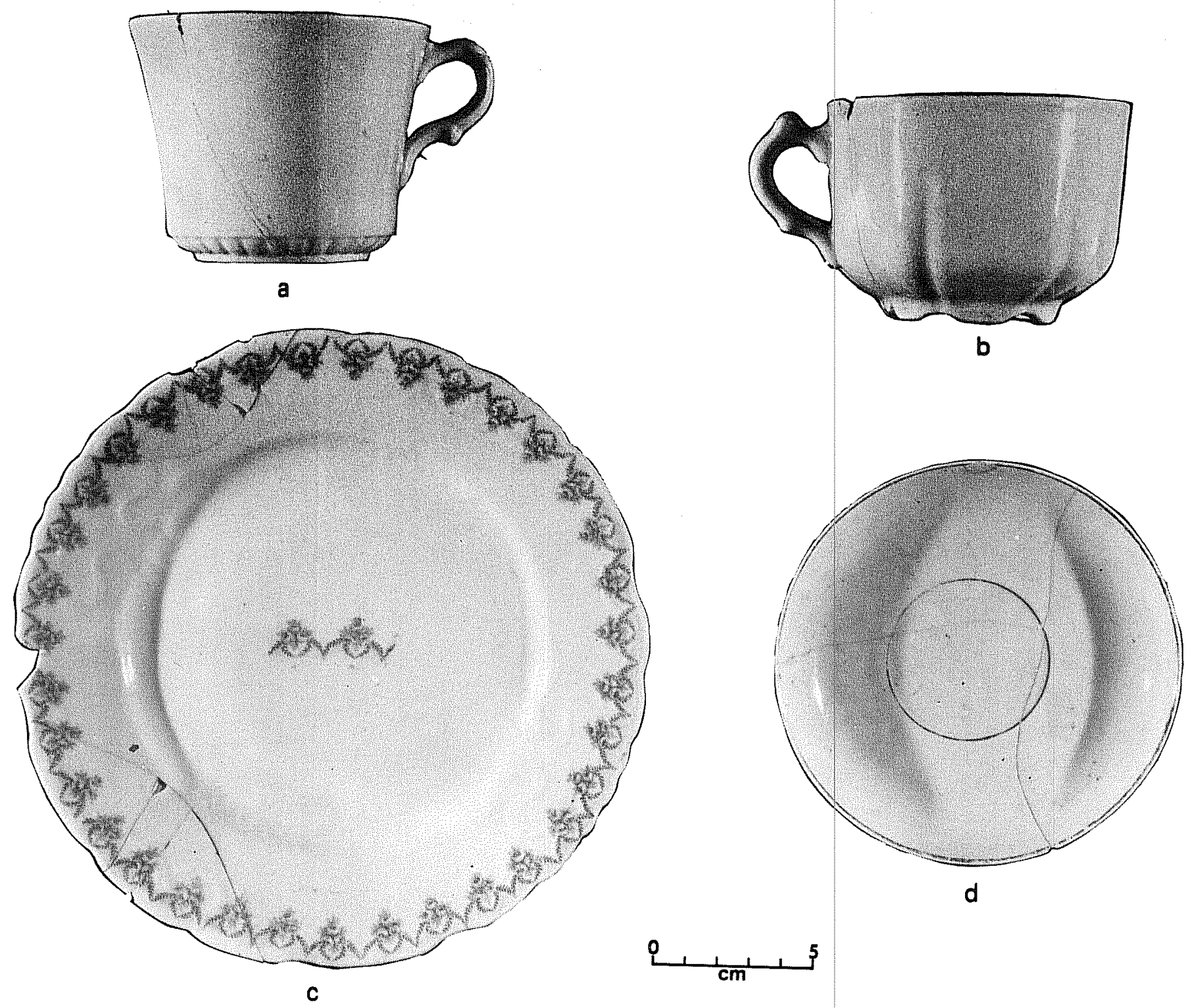

Figure 21. Selected Artifacts from Features 4 and 4w: Restored Ceramics. a, molded white earthenware cup; b, molded white ironstone cup; $c$, fine white porcelain plate with repousse and decalcomania decoration; $d$, gold banded white porcelain saucer. 
Figure 22. Selected Artifacts from Features 4 and 4W: Restored Table wares. a, white ironstone, impressed mark: TRENTON CHINA CO., TRENTON, N.J. Operated from 1859 to 1891 (Barber 1904:68); b, white earthenware with decalcomania design in green and lavender. Printed mark: CLIFTON/T. Clifton is the pattern name, maker was C. C. Thompson Pottery Co., East Liverpool, Ohio, started in 1890 (Barber 1904:110); c, Rockingham glaze on molded pitcher; d, syrup dispenser, U.S.Q.M.D., ironstone; e, fine white porcelain plate with repousse design, no mark; $f$, white earthenware plate with decalcomania design. Printed mark: J\&G MEAKIN/HANLEY/ENGLAND/SEMI PORCELAIN. ca. 1907 (Godden 1964:427). 


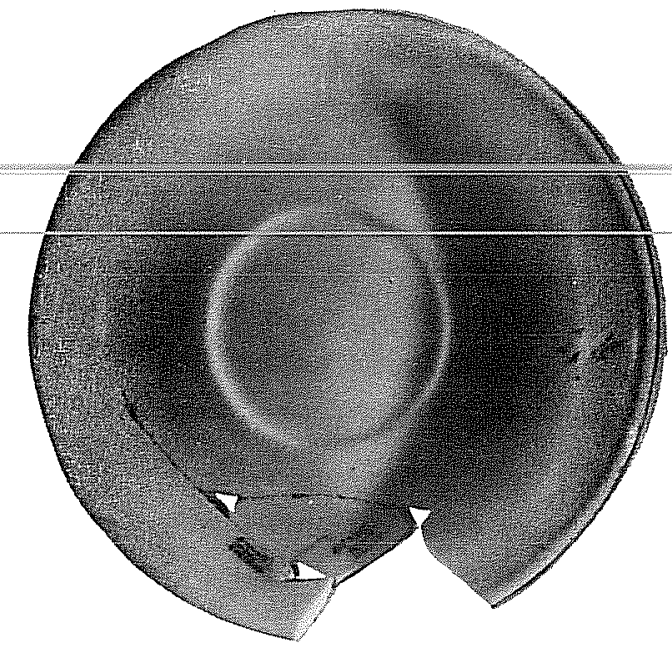

a
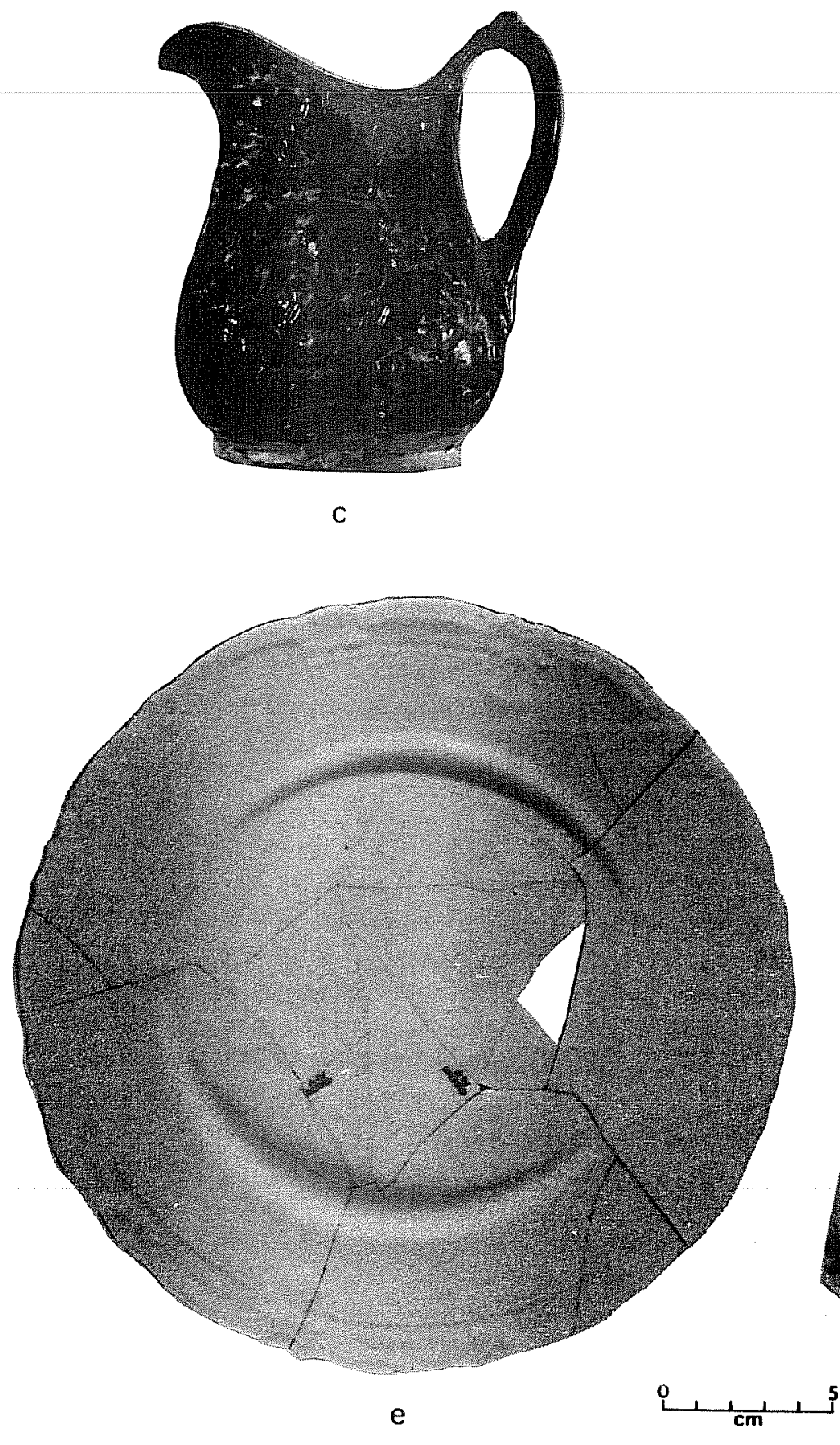

e

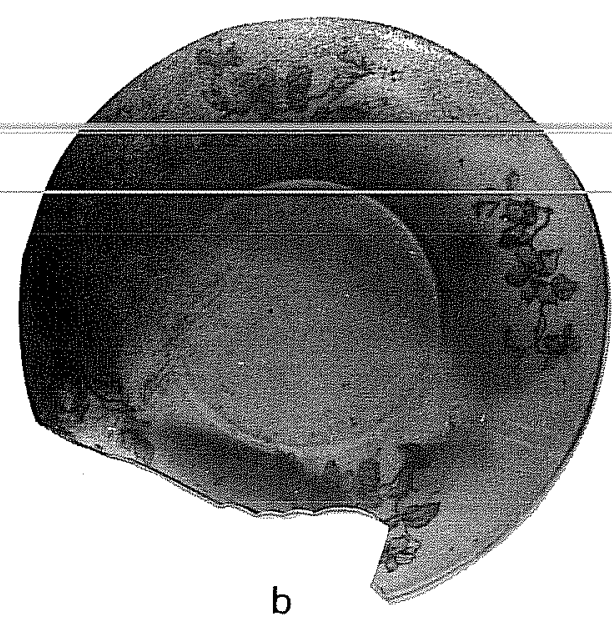

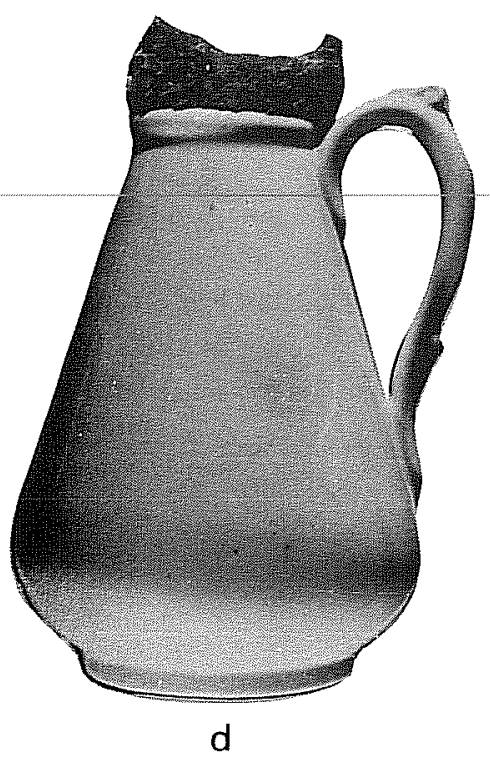

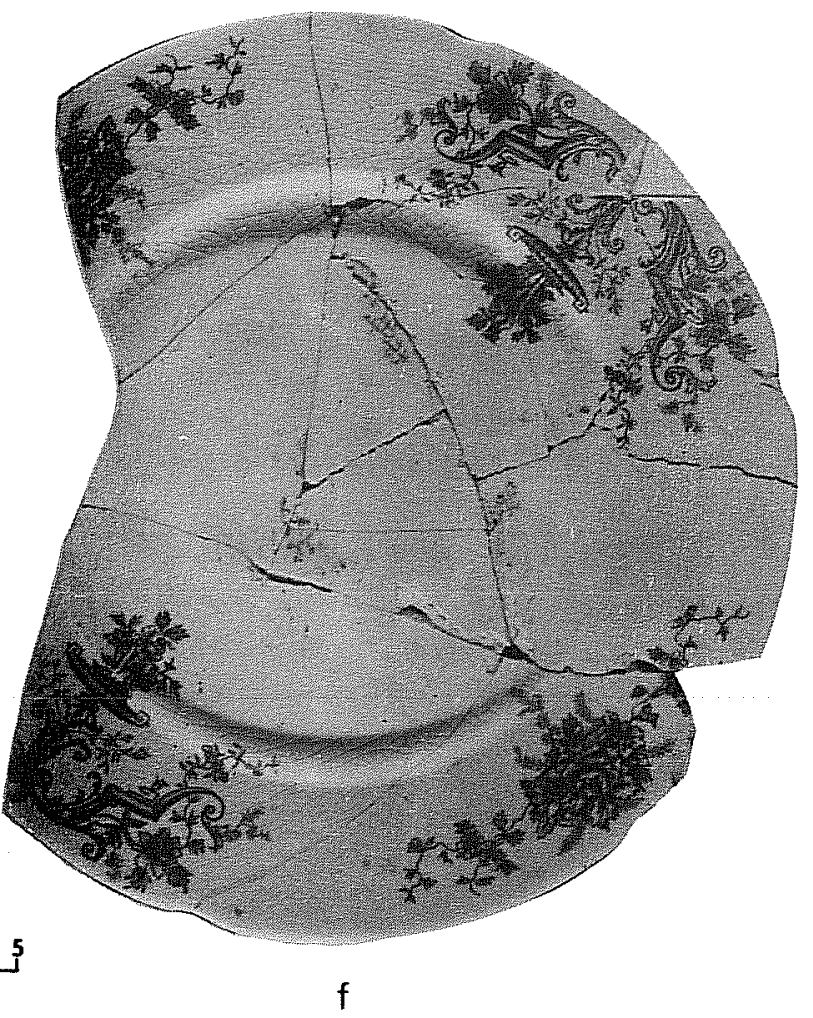


a
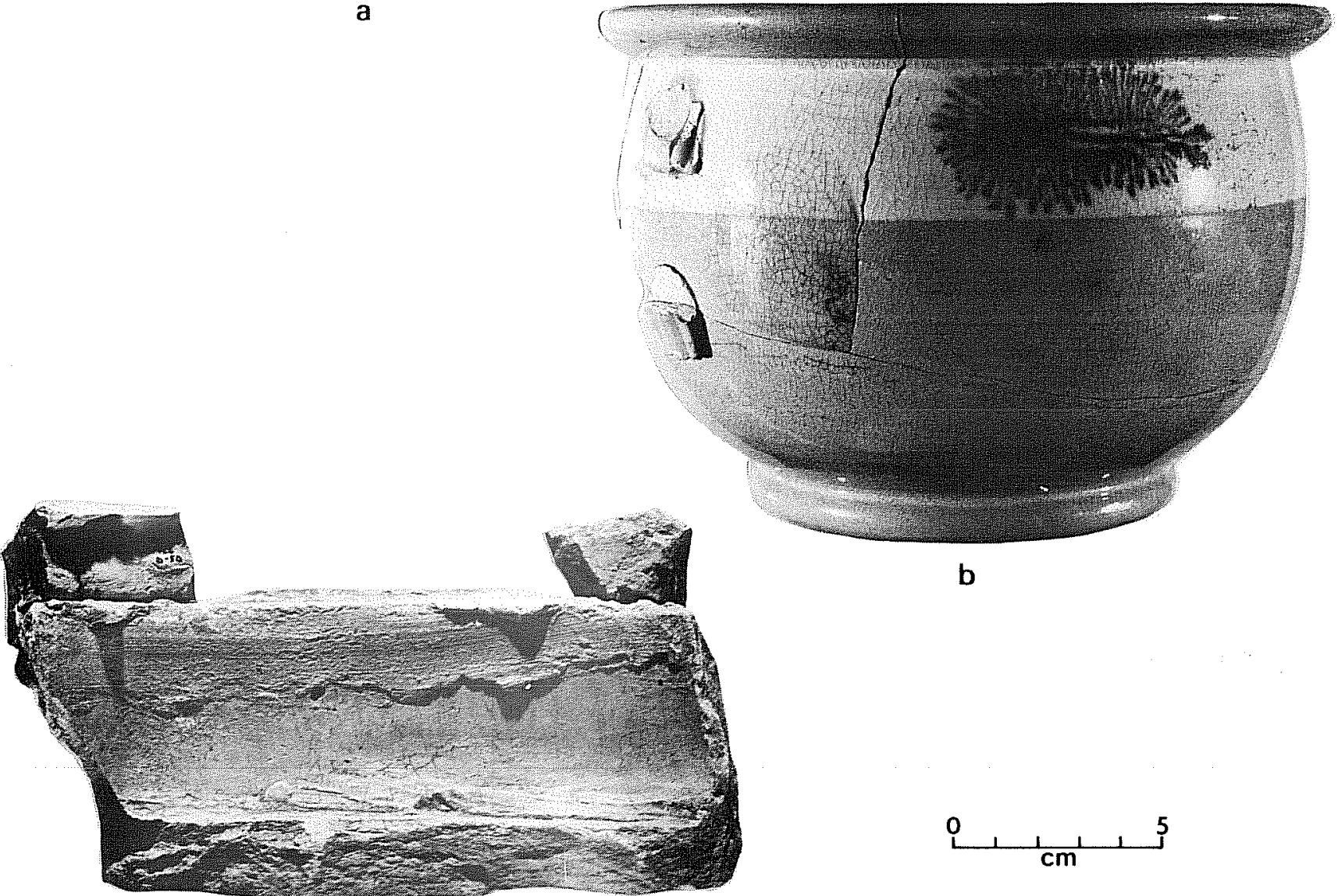

b

C

Figure 23. Selected Artifacts from Features 4 and 4w: Restored utility wares. $a$, locally made stoneware jug, salt glazed; b, yellowware chamber pot with mocha decoration; $c$, ceramic charcoal stove. 

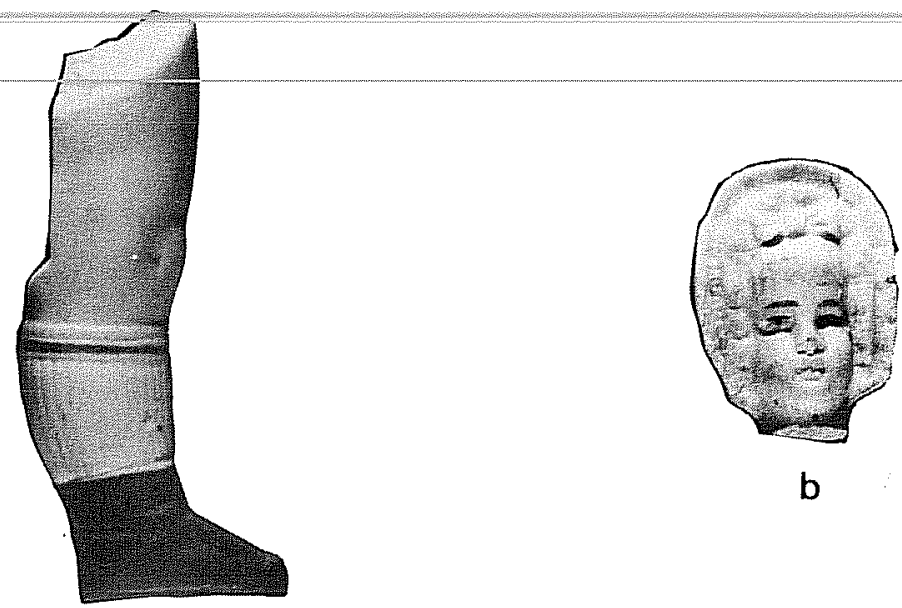

b

a

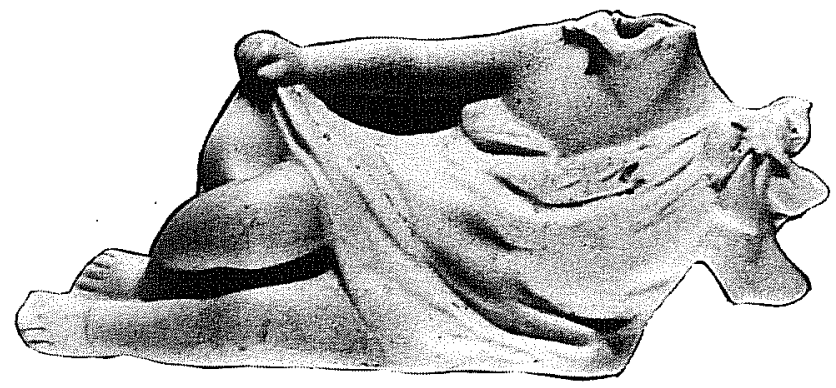

c

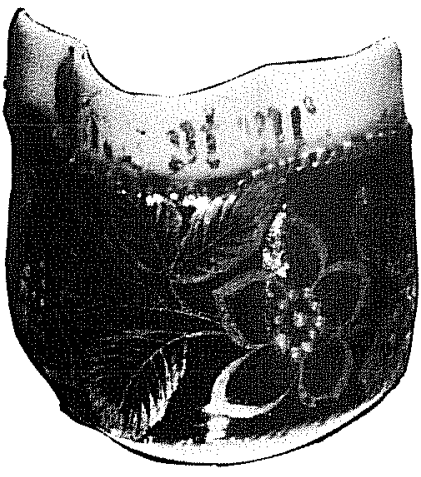

d
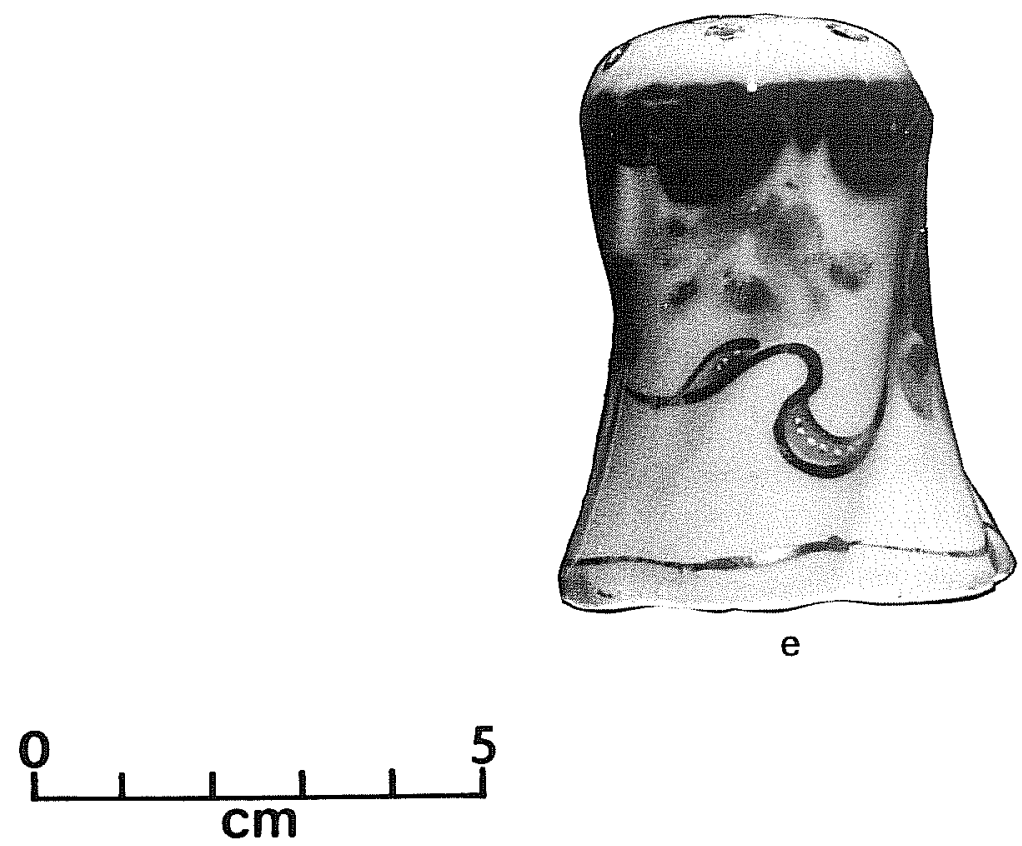

Figure 24. Selected Artifacts from Features 4 and $4 \omega$ : Porcelain. a, bisque doll's leg; b, bisque doll's head; c, bisque figurine; d, underglaze blue decorated porcelain with gold overglaze design; e, underglaze blue decorated salt cellar with overglaze designs of pink, green and gold. 
Figure 25. Selected Artifacts from Features 4 and 4W: Glass Table Ware. a, clear glass with etched pattern, stemmed goblet; b, clear glass, wineglass; c, clear glass goblet; $d$, clear glass tumbler with etched bands; $e$, clear glass tumbler with octagonal base; $f$, clear glass tumbler with etched design; $g$, pressed glass creamer; $h$, pressed glass salt shaker; $i$, pressed glass tumbler. 

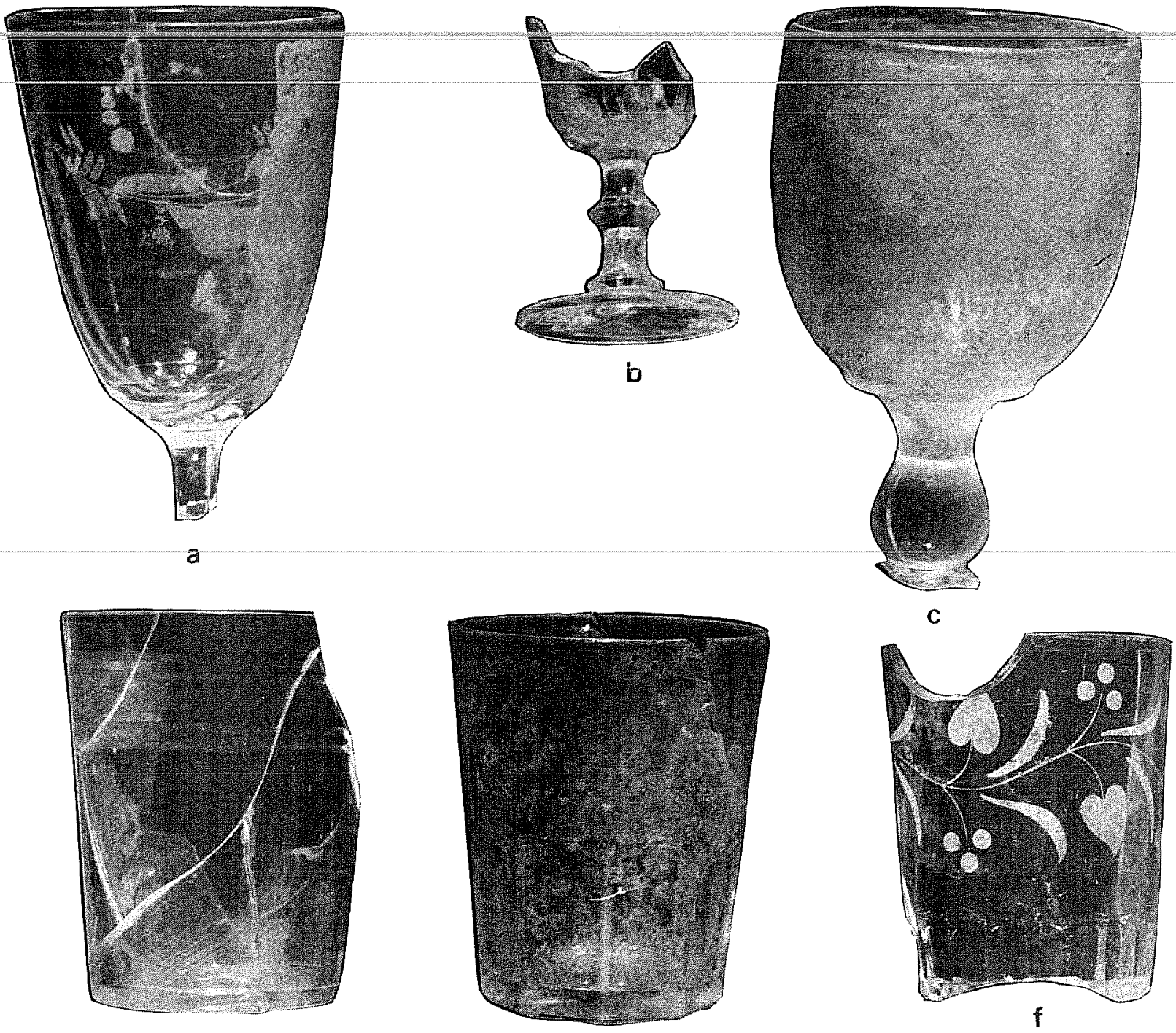

d
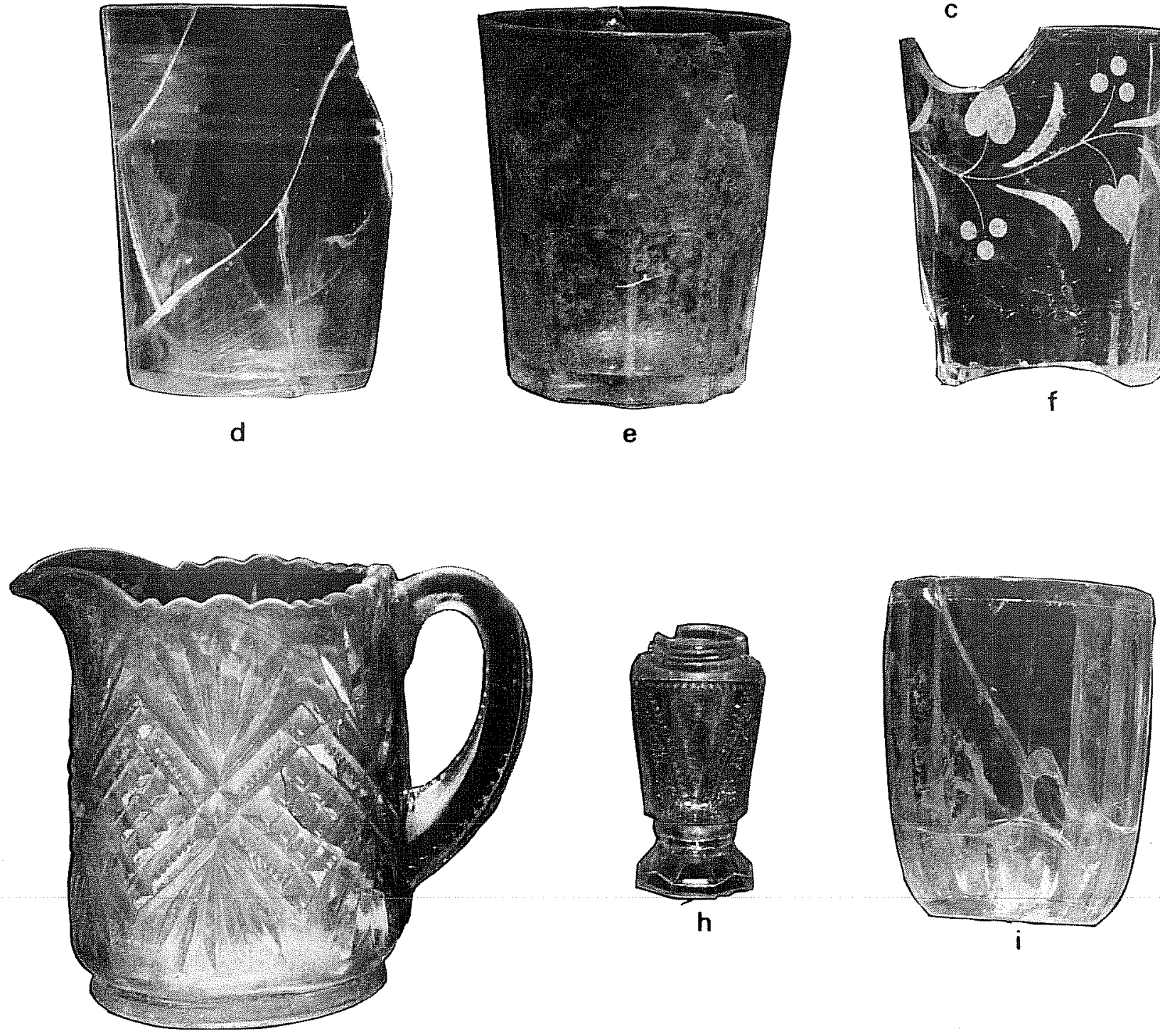

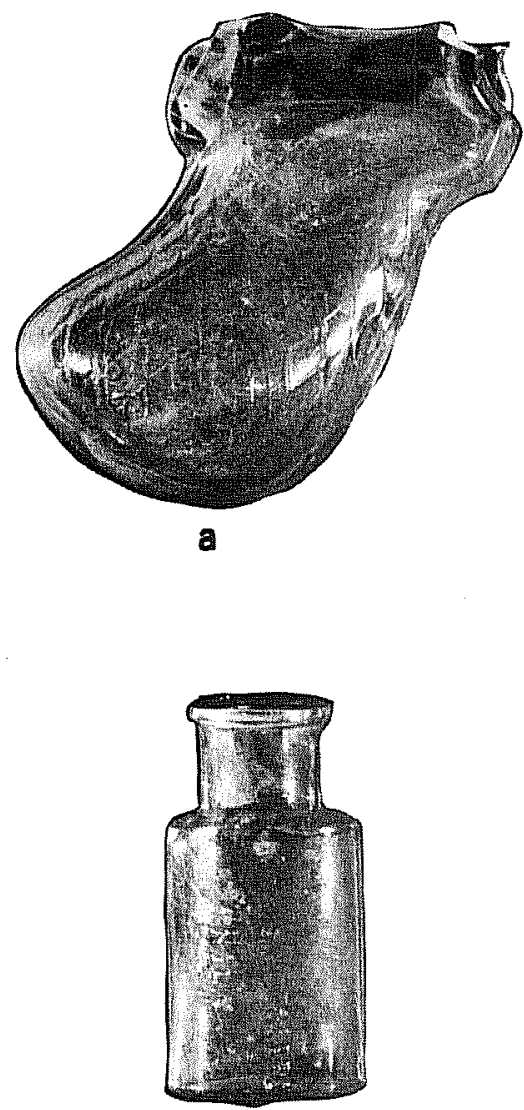

d
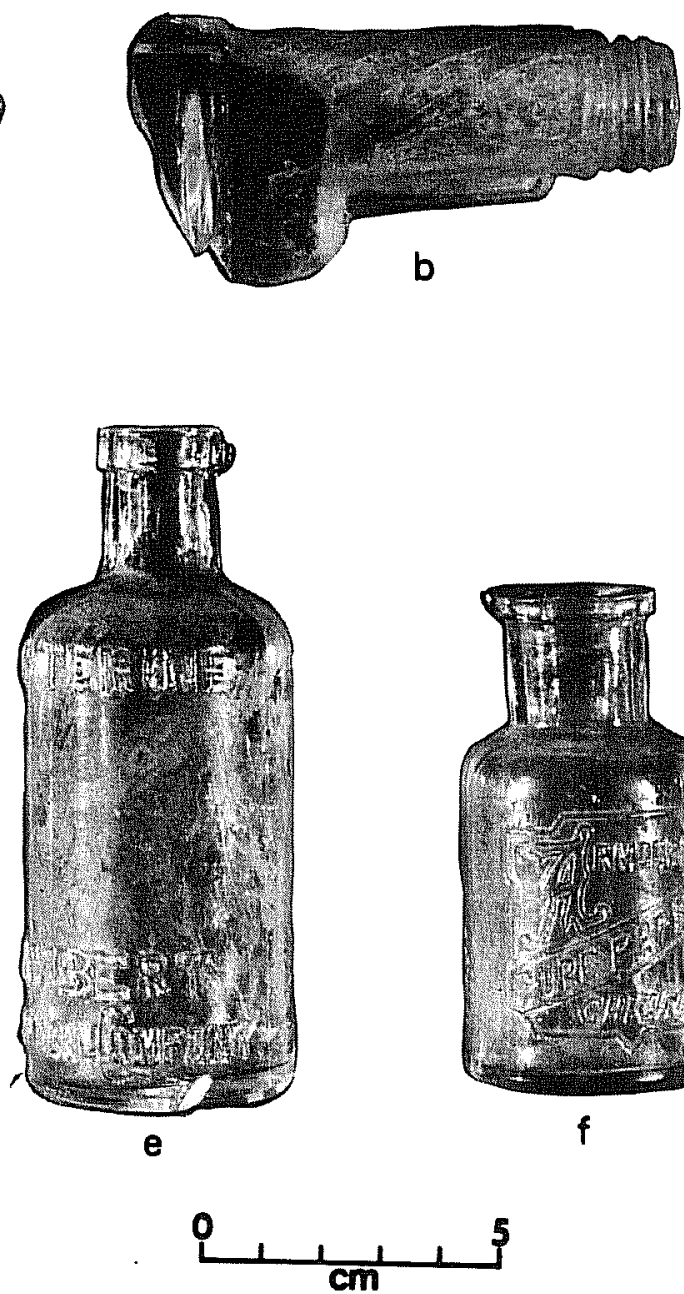
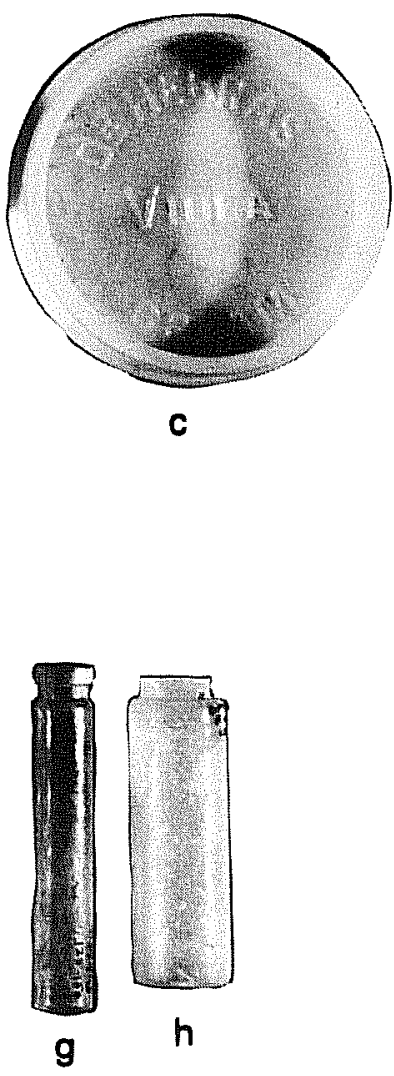

Figure 26. Selected Artifacts from Features 4 and $4 w$ : Glass Containers. $a, b$, gun shaped bottle; c, shallow milk glass jar. DR HEBRAS/VIOLA/CREAM; d, clear medicine bottle, JOHN WYETH \& BRO/PHILA; e, clear medicine bottle, LISTERINE/LAMBERT/PHARMACAL COMPANY; $f$, clear medicine bottle, ARMOUR \& CO/PURE PEPSIN/CHICAGO; $g$, clear vial; $h$, frosted vial with sheared lip. 
Figure 27. Selected Artifacts from Features 4 and $4 w$ : Glass Containers. a, WYCKOFF \& COS/UNION/BLUING, aqua; $b$, snuff bottle,
brown; $c$, shoe polish bottle, aqua; d, soda bottle, Wm.ESSER/SAN ANTONIO/TEXAS, aqua; $e$, flask, clear; f, food jar, clear. 


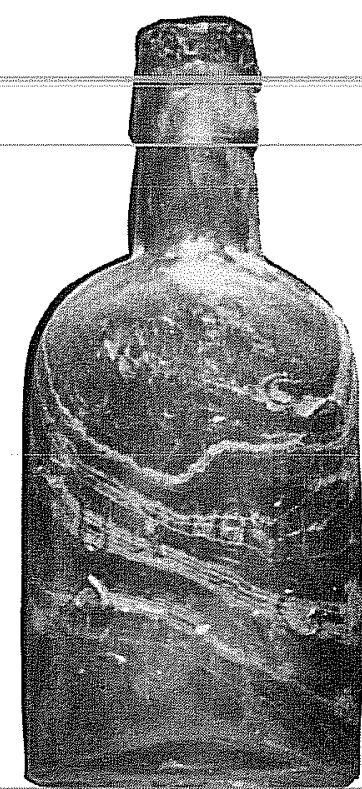

a

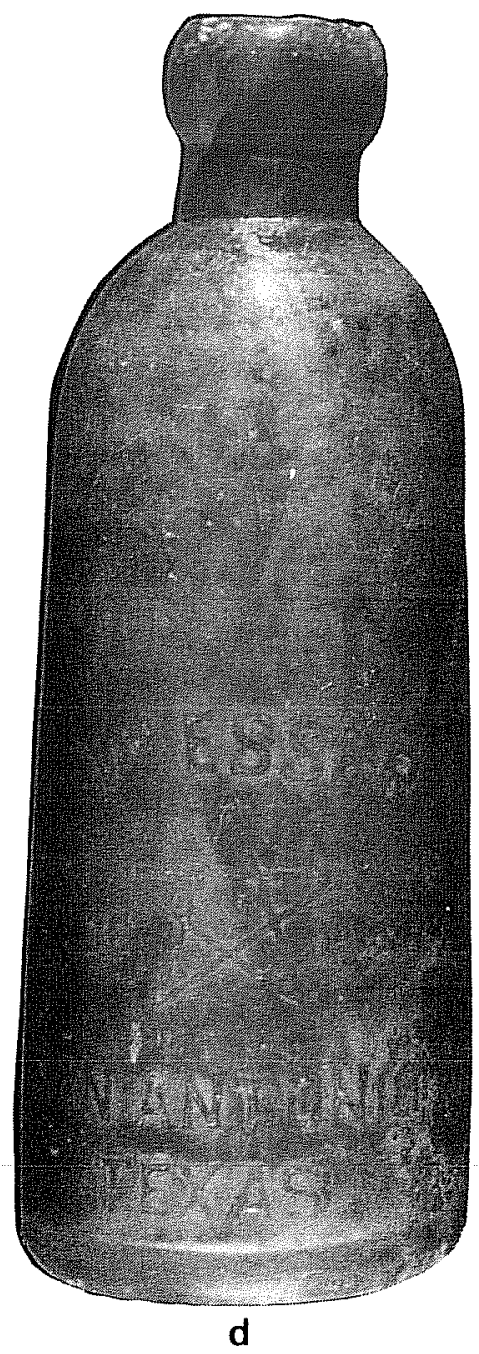

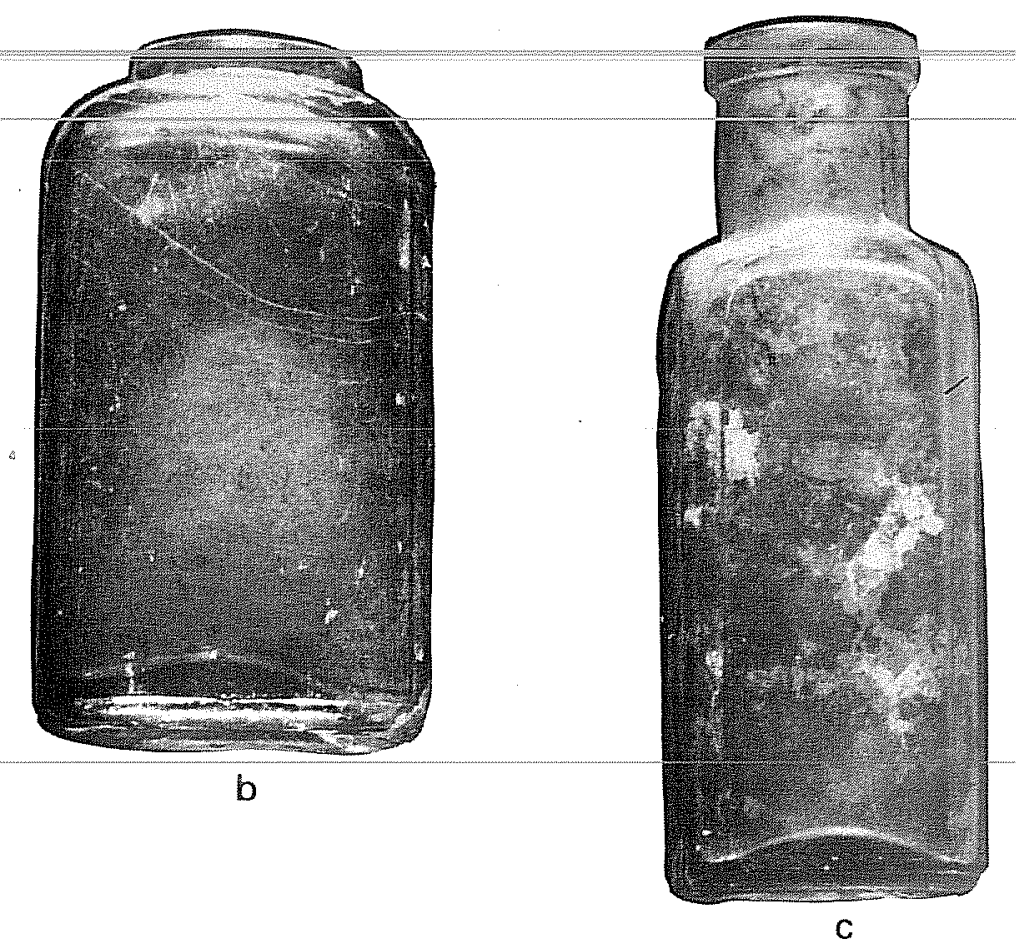

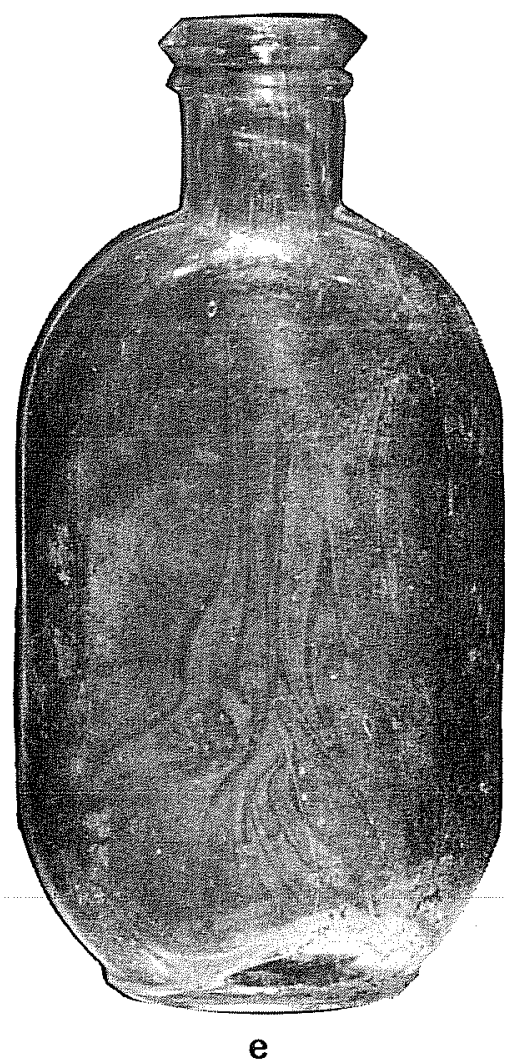

ㄴ,, $\mathrm{cm}^{5}$

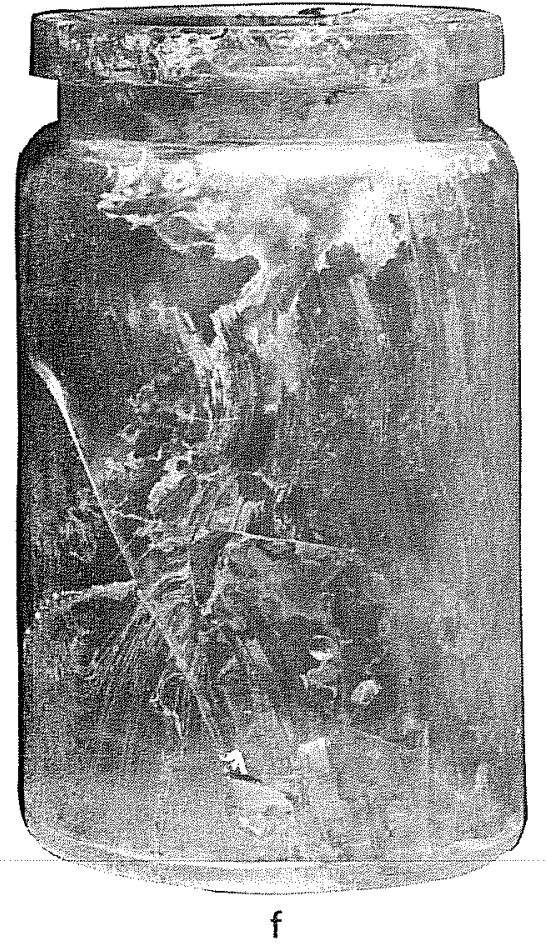




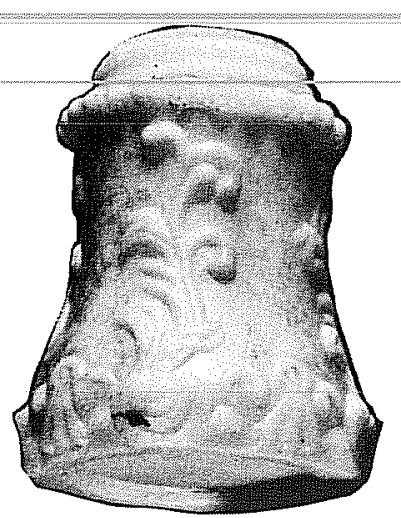

a

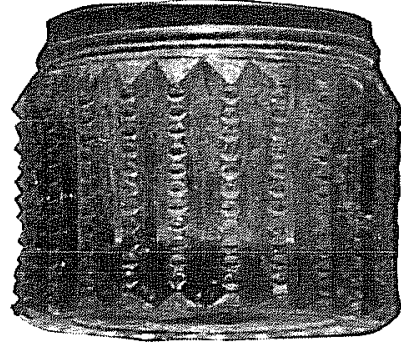

b

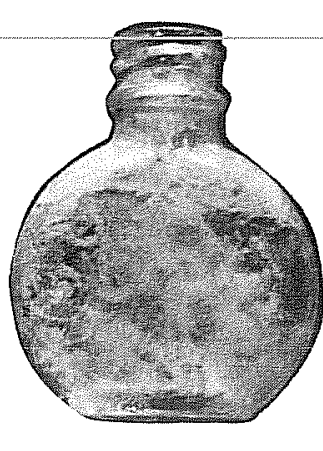

c

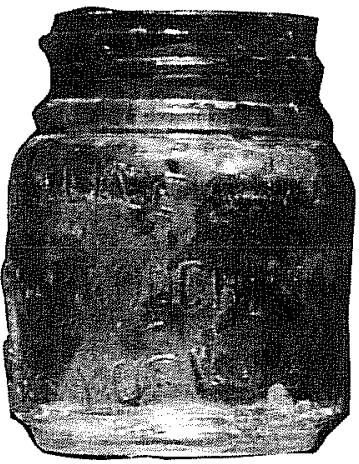

d

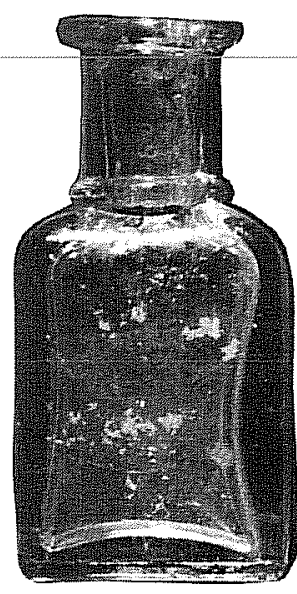

e

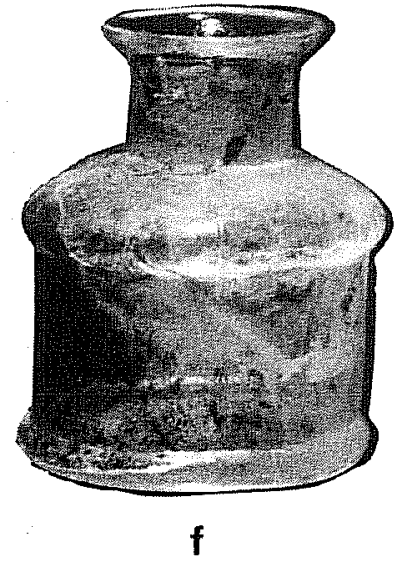

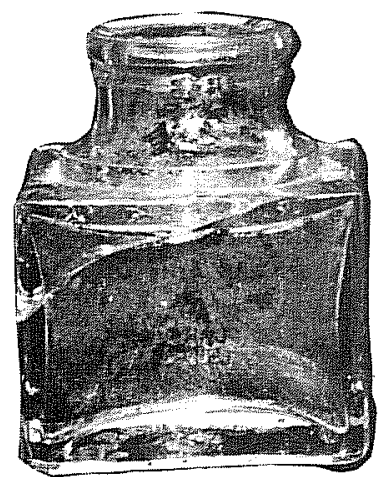

$\mathbf{g}$

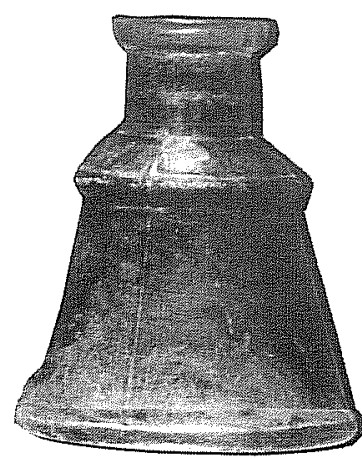

h

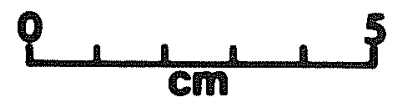

Figure 28. Selected Artifacts from Features 4 and 4W: Ointment and Ink Bottles. a, milk glass ointment jar; b, pressed glass ointment jar, clear; c, perfume or ointment bottle, clear; $d$, VASELINE/CHESEBROUGH/NEW YORK, clear; $e$, ointment bottle, clear; $f$, ink bottle, S.M. Co. on base, clear; $g$, ink bottle, THOMAS \& CO. on base, aqua; $h$, ink bottle, clear. 


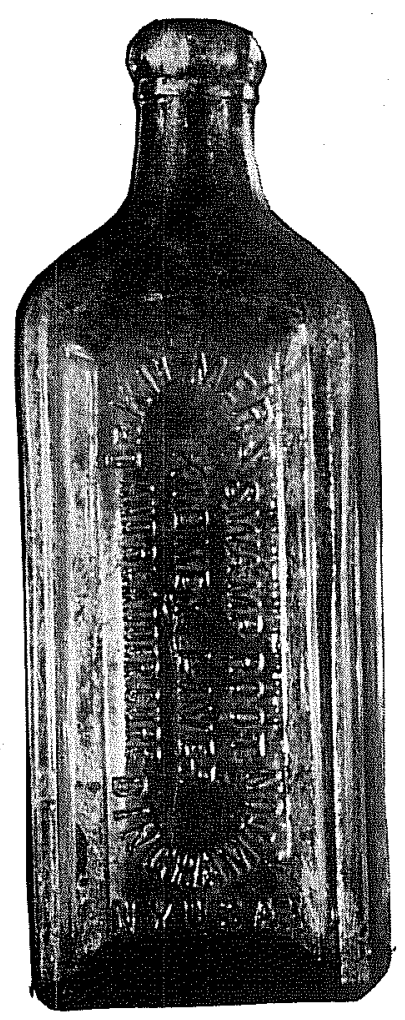

a

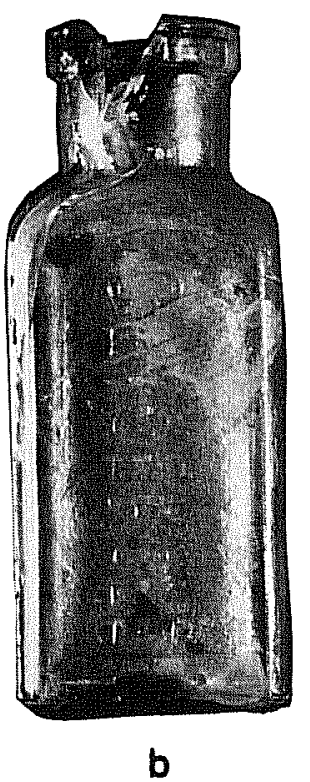

b

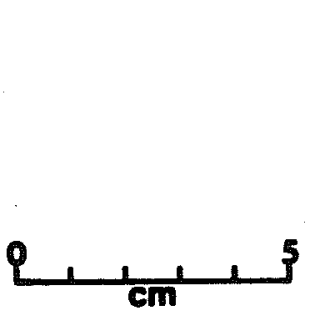

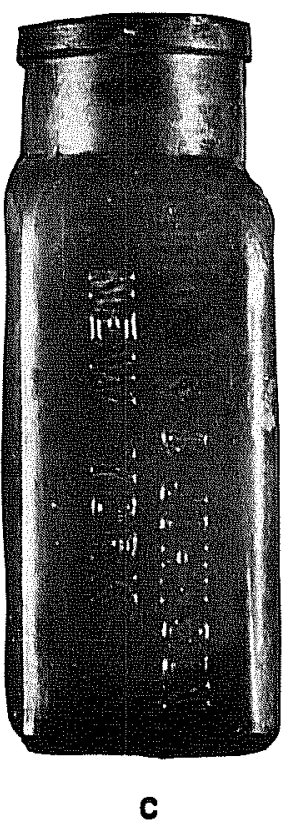

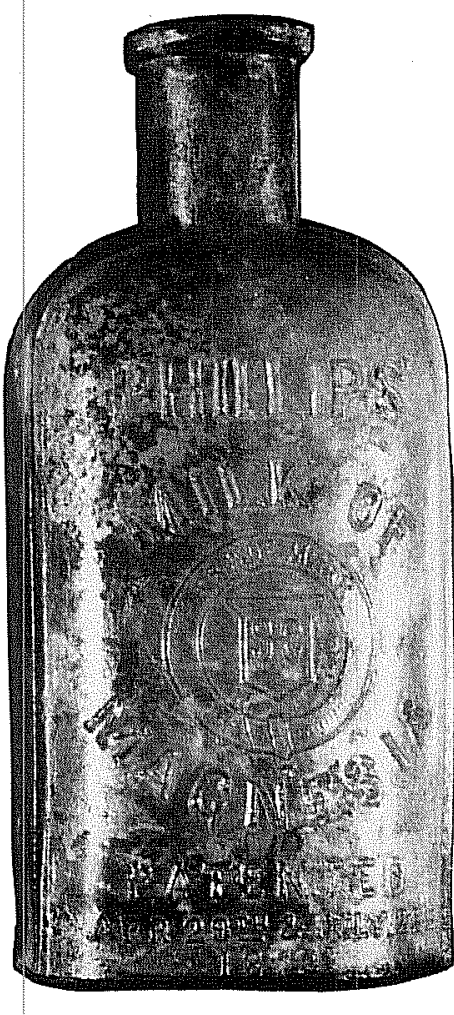

d

Figure 29. Selected Artifacts from Features 4 and 4W: Medicine Bottles. a, DR. KILMER'S SWAMP ROOT/KIDNEY LIVER/AND BLADDER CURE/BINGHAMPTON/N.Y. U.S.A.; b, GLYCEROLE; $c$, JOHNSON \& JOHNSON/NEW YORK; $d$, PHILLIPS' MILK OF MAGNESIA/PATENTED/APR. 28th \& JULY 22nd/1873. 


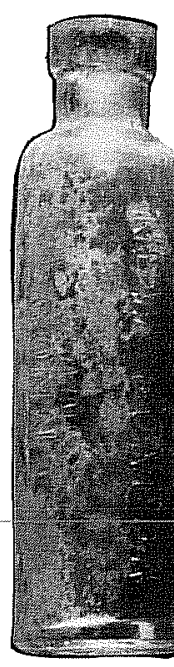

a

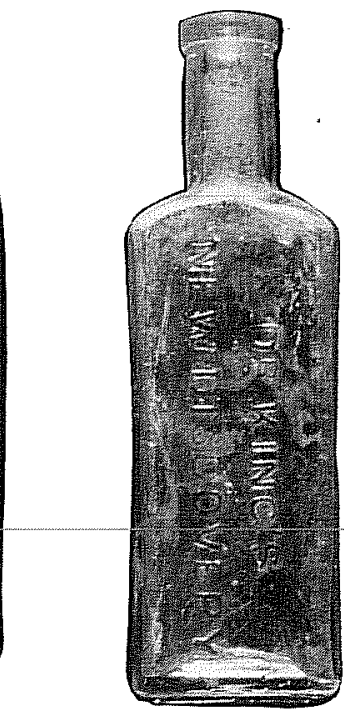

b

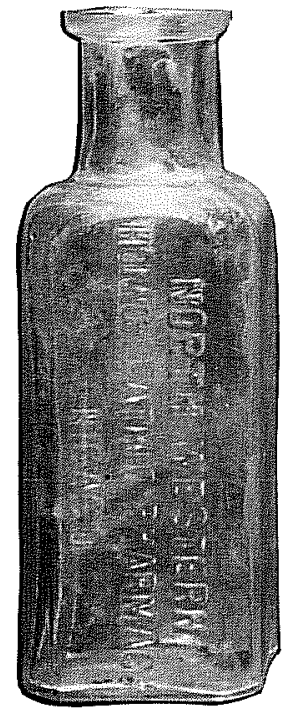

C

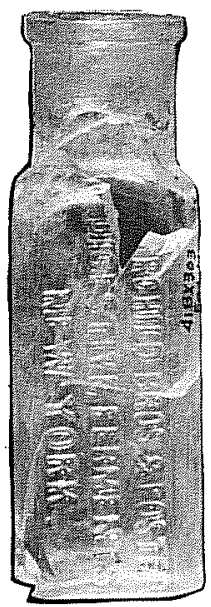

d

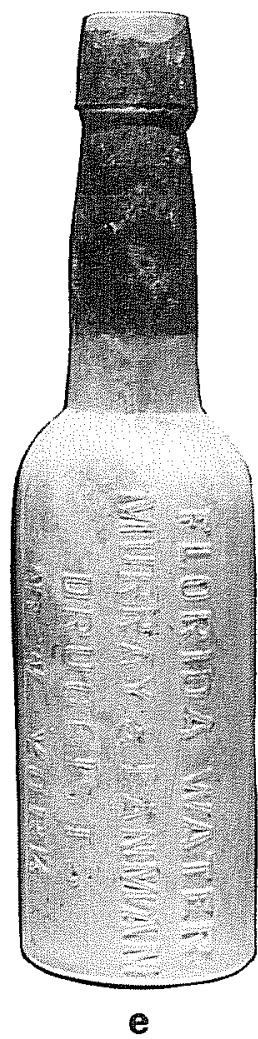

e

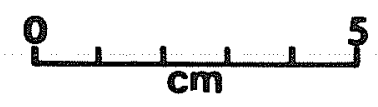

Figure 30. Selected Artifacts from Features 4 and 4W: Medicine Bottles. $a$, DR. THOMPSON'S/EYE WATER/NEW LONDON/ CONNI, clear; $b$, DR. KING'S NEW DISCOVERY/H.E. BUCKLEN \& CO./CHICAGO, ILL., aqua; $c$, NORTHWESTERN/HOMEOPATHIC PHARMACY/CHICAGO, clear; $d$, --IRCHILD BROS \& FOSTER/DIGESTIVE FERMENTS/NEW YORK, clear; $e$, FLORIDA WATER/MURRAY \& LANMAN/ DRUGGISTS/NEW YORK, aqua. 
Figure 31. Selected Artifacts from Features 4 and 4W: San Antonio Druig Store Bottles. a, ALAMO DRUG STORE/A. DREISS/SAN ANTONIO TEX; $b$, YARBROUGH \& GILES/DRUGGISTS/SW COR HOUSTON \& SOLEDAD STS./SAN ANTONIO TEX; $c$, Wm APPM(ann)/APOTH(ecary)/SAN ANT(onio); d, KALTEYER \& SCHUCHARD/SAN ANTONIO; $e$, KALTEYER \& SON/DRUGGISTS/SAN ANTONIO; $f, C$. SCHASSE/ 75 COMMERCE/SAN ANTONIO; g, P.G. LUCAS/DRUGGIST/ MISSION DRUG STORE/727 SO. ALAMO ST., SAN ANTONIO, TEXAS; $h$, ALAMO DRUG STORE/A. DREISS/SAN ANTONIO, TEXAS; $i$, JAMES CALVIN/DRUGGIST/ 144 W. COMMERCE ST./COR. NAVARRO. 
Figure 34. Selected Artifacts from Features 4 and $4 \omega:$ Personal Items. $a$, blue-glazed clay marble; b, unglazed clay marble; c, glass marble; $d$, pendant; $e$, cuff link; $f$, composition shirt stud; $g$, brass collar button or shirt stud; $h$, metal propeller blade TO STOWERS/I'D FLY FURNITURE/TO BUY. G.A. Stowers Furniture Company began operation in 1889 (Woolford 1963:159); $i$, carved bone advertising token, SWIFTS/PREMIUM/ HAM; $j$, GOOD FOR 1 PINT OF MILK, reverse CENTRAL/DAIRY/ALEX UHL. Operated under this name until 1896 (Appler 1895); k, G00D FOR 10\& IN TRADE, reverse, ---IA SALOON/---ELM/ST; 1, advertising token, PRESENTED/TO A GOOD BOY/WEARING A/ROYAL BRAND SUIT/STYLE/DURABILITY/WORKMANSHIP/EVERY GARMET/GUARANTEED, reverse, EXCELLENCE. AWARD OF MERIT. SUPERIORITY/ FAMA SEMPER VIRET, brass; $m$, GAY OLA/ITS BETTER, reverse, COMPLIMENTS OF THE GAY OLA CO/MEMPHIS, brass; $n$, token in shape of early cash register, silver plated; 0 , I'M FROM TEXAS/YOU CAN'T STEER ME, reverse, COMPLIMENTS OF PHIL. V. ZCELLNER/WITH/STRANSKY-KRAUS CO/TAILORS/CHICAGO, brasS. 

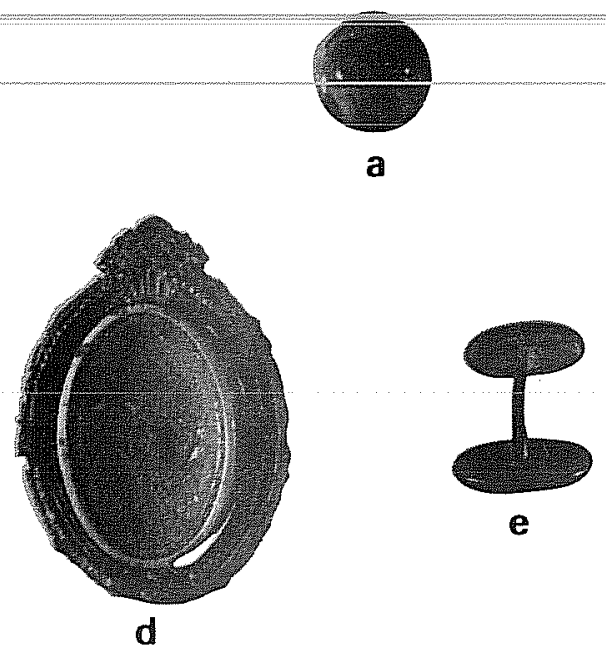

e

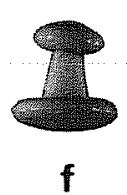

$f$
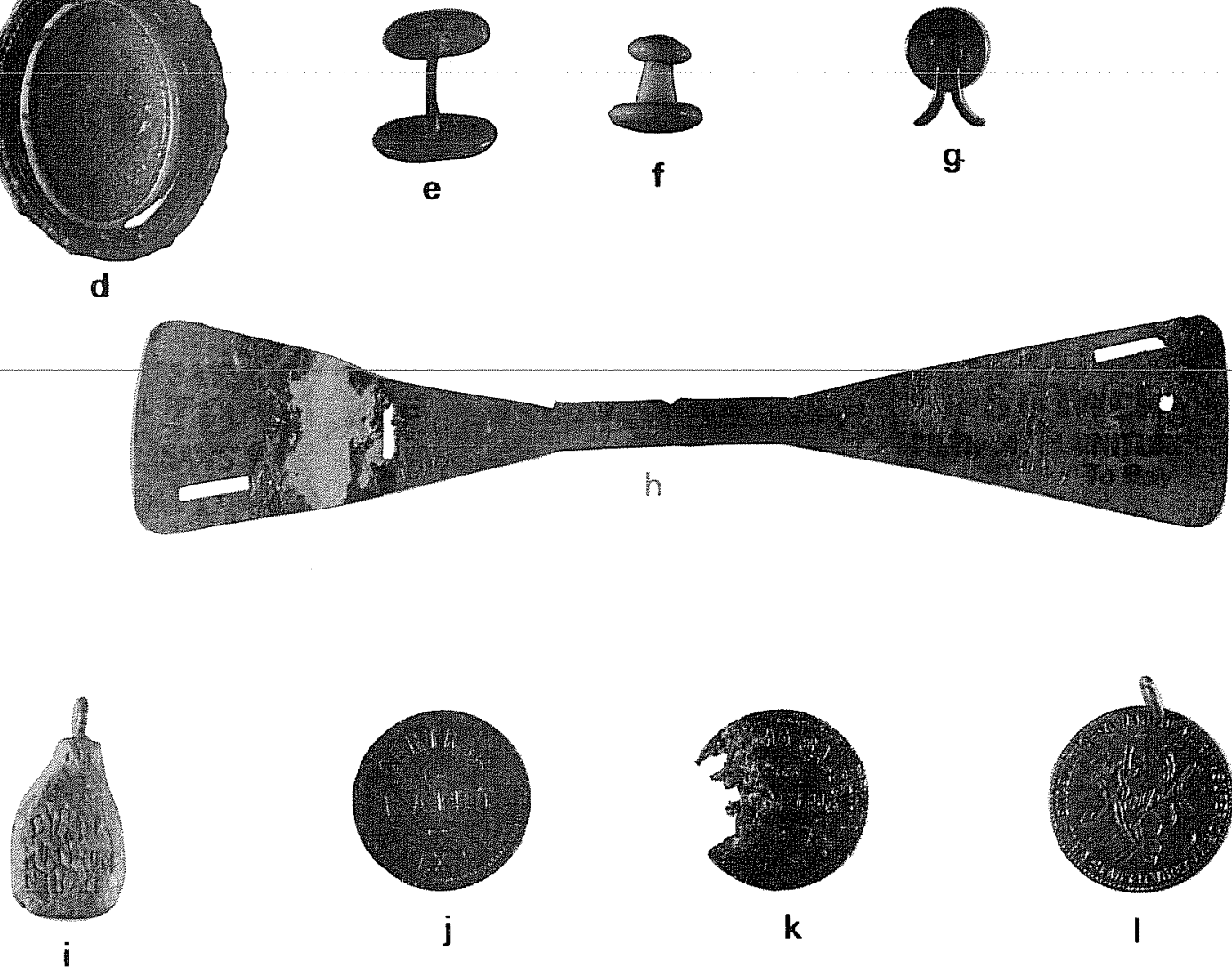

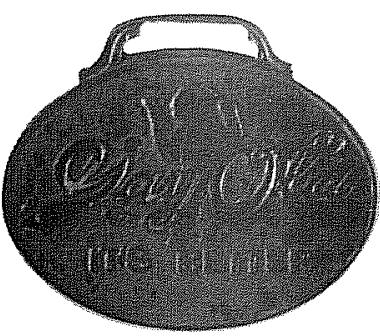

$m$

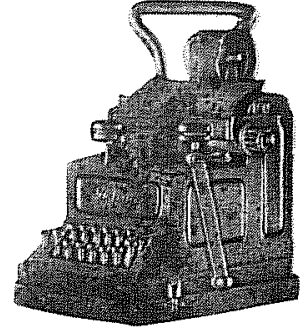

n

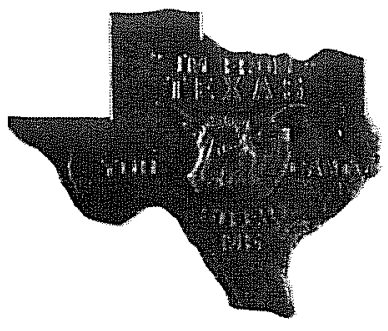

o

$0,1,1, \quad 1 \quad 5$
$\mathrm{~cm}$ 

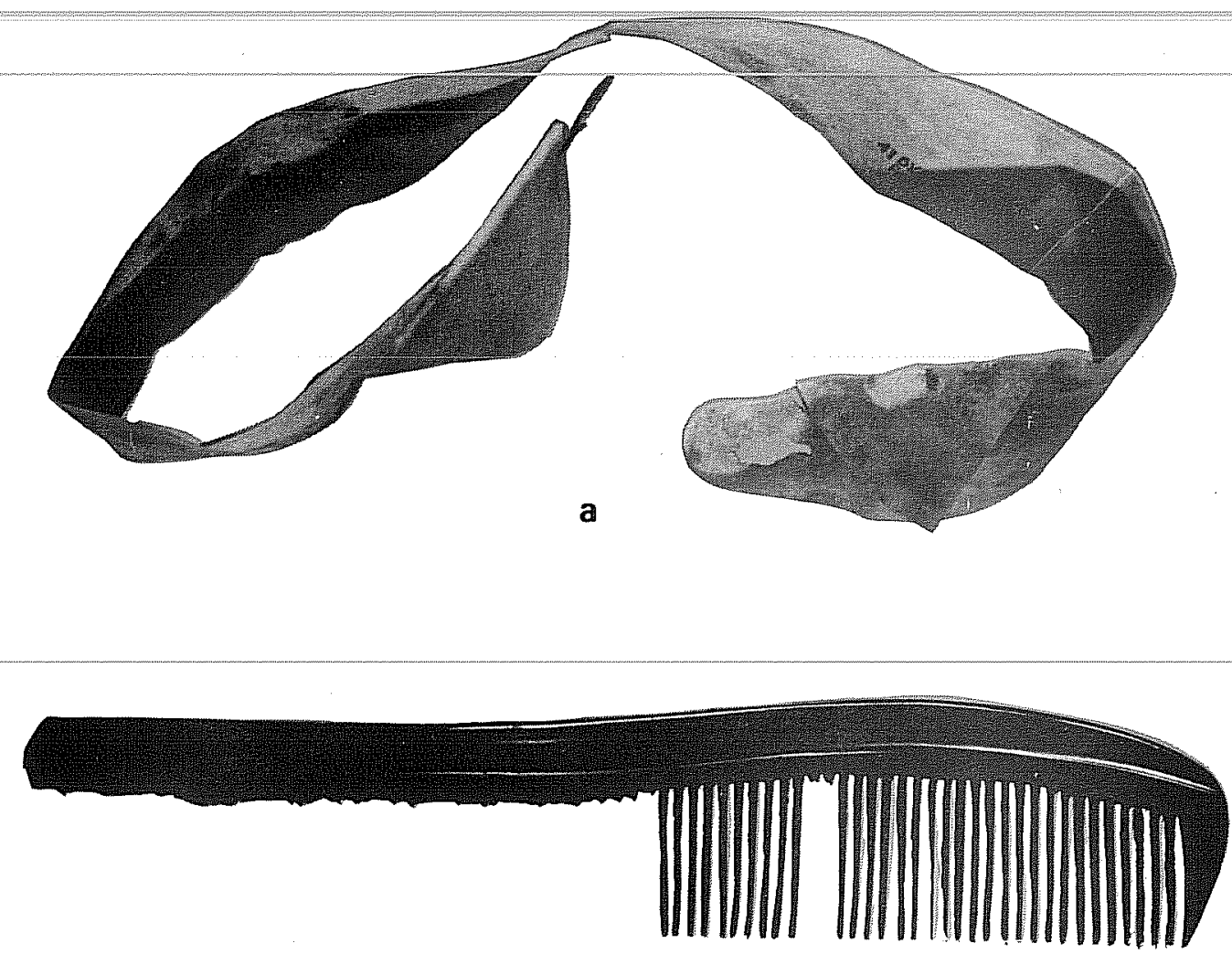

b

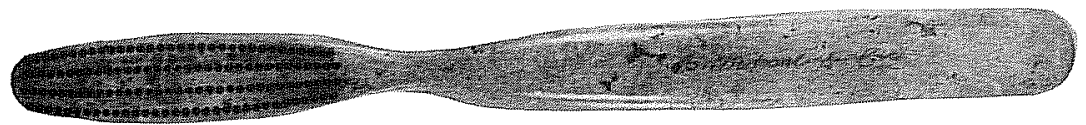

$\mathbf{C}$
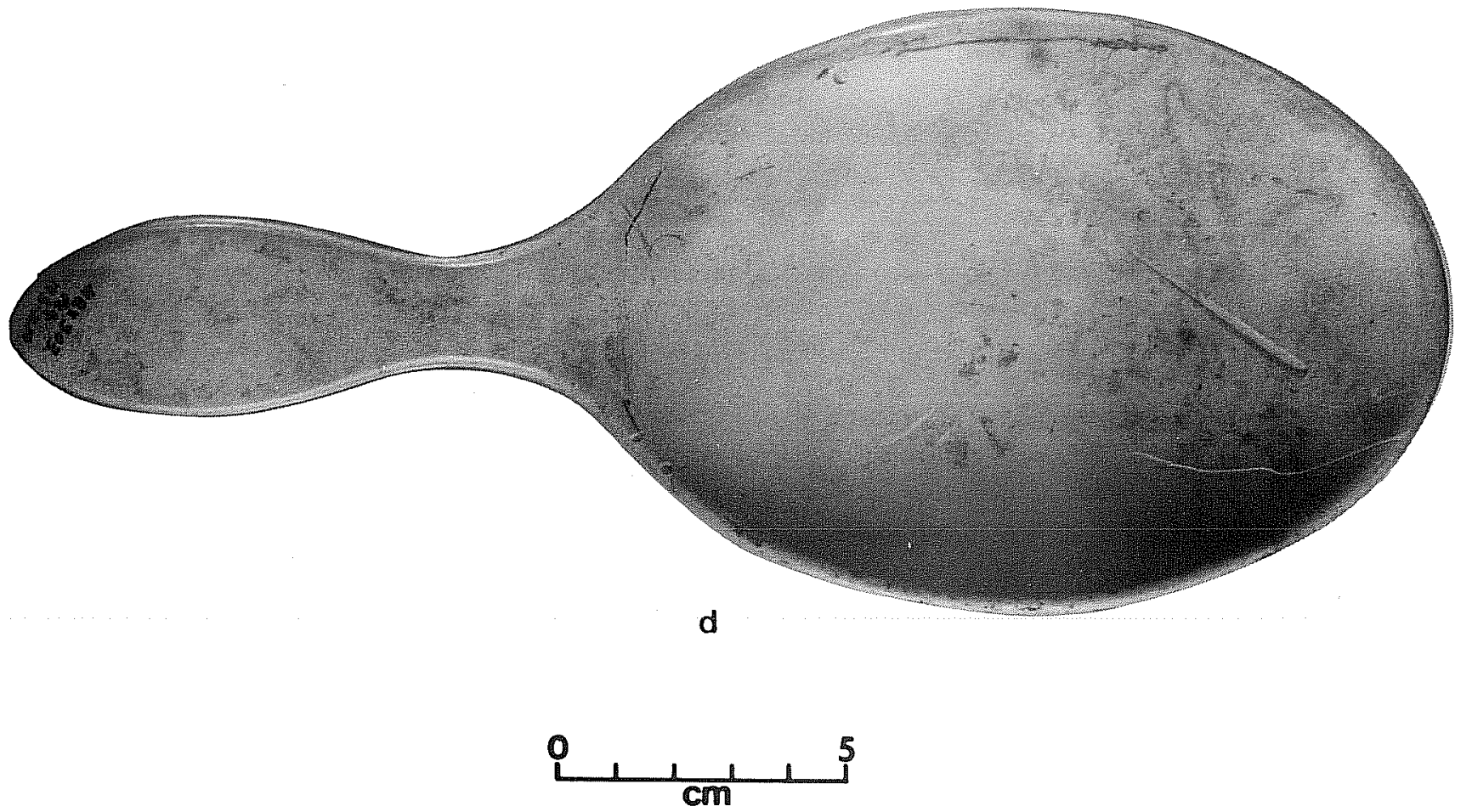

Figure 35. Selected Artifacts from Features 4 and 4w: Personal Items. a, celluloid collar, USE A LEVER OR SEPARABLE BUTTON/NO. 432; b, composition comb; c, bone toothbrush; d, celluloid mirror frame. 


\section{SUMMARY}

The primary focus of archaeological and historical investigations in the Arciniega Street area was to inventory and assess the nature of cultural resources prior to the construction of a luxury hotel on NCB 901 and portions of NCB 155. Determinations of the effect of construction on these resources were then to be made. Historical research was conducted concomitantly with archaeological excavations, enhancing the predictive and interpretive capabilities of the field work.

The field work component of the Arciniega Project consisted of 19 days of excavation in May and June of 1976. During that period, with the aid of a backhoe, 203 cubic meters of earth were removed from 321 meters of trench and other units. When feature and room fill is included, the total volume of excavated soil reaches 269 cubic meters.

Historical research documented 12 residential and commercial structures situated on NCB 901 , or that portion of the block remaining after the construction of Durango Boulevard. Three were still standing in 1976 and will be renovated for use by the hotel: $422 \mathrm{~S}$. Presa, 204-206 Arciniega and 220 Arciniega. The remaining nine had been razed prior to the investigations and all but one of their foundations buried and covered with asphalt paving. The location of one (509 S. Alamo) was never determined; two locations were determined but not investigated (210 and 232 Arciniega); and five locations were determined and investigated to varying degrees (426, 416-418 and $412 \mathrm{~S}$. Presa, 224 and 228 Arciniega, and 501-505 S. Alamo) during the archaeological field work portion of the project.

Seven cultural features, unattached to any of the residential structures, were archaeologically identified and investigated: three irrigation ditches, one cistern with a possible cooling chamber, one domestic trash pit, one latrine and one pit of undetermined function.

No prehistoric artifacts, features or structural remains were recovered during the investigations, either from the archaeological excavations or from the engineering cores.

Historical documentation suggests that NCB 901 was utilized completely for agricultural purposes until at least 1811-1813 and perhaps as 1ate as 1840-1841. Trenches in the southwest and southeast corners and in the center of the block cut across what are interpreted as untined irrigation ditches, postulated as having been laterals of one or both of the major acequias known to have been located close to this area. No associated artifacts were recovered from these ditches, however.

The decade of the 1880s saw the construction of most of the houses in the project area; the earliest two were built between 1841 and 1851 , the latest in 1912. At the present time there is no historical documentation for any substantial structure on the block prior to 1840 , and the preliminary results of the archaeological investigations support this fact. Neither architectural construction characteristics nor artifacts recovered from foundations and features appear to pre-date 1840. 
Limited testing on Lot 26 of NCB 155 has led to the conclusion that the wall ruin still visible is not a portion of a larger structure, Spanish Colonial or otherwise. Preliminary historical documentation suggests that if a cuartel was actually constructed on NCB 155, its location would be where the German-English School is now, that is, located underneath the City's Planning Department. There is still some question, however, as to whether such a structure was ever actually built. The Arciniega house has been determined to have been located on NCB 155, at the corner of E. Nueva and S. Alamo.

At the present time, archaeological investigations have located at least a portion of every archaeological landmark save one which historical documentation suggested would be in the impacted portion of the project area. This single exception is a large cistern, supposedly brick-lined below-ground and built of wood for two stories above-ground, which several early sketches of NCB 901 show to have been located east of 228 Arciniega Street.

Unless subsequent historical research should uncover evidence of any substantial structures built prior to 1840 , the three houses still standing on NCB 901 are representative of all the houses built on this block. No differences could be determined between the exposed foundations of the standing and previously destroyed structures. Nevertheless, these three structures are listed on the National Register of Historic Places Inventory; any modifications to them or to their immediate surroundings must comply with the National Historic Preservation Act of 1966. Due to the uncertainty of renovation plans for at least two of these structures (422 S. Presa and 220 Arciniega) at the time of the 1976 field investigations, additional archaeological work in the vicinity of these houses may be necessary at some future time.

Additional features, especially latrine and trash pits, will undoubtedly be uncovered during the construction of the hotel. Those that were excavated, however, are considered typical of each type of feature, are well documented, and have yielded a sufficient quantity of artifactual and subsistence material for adequate interpretation of the nature and function of these types of features.

During the past two years both research on the data gathered and the construction of the hotel have proceeded apace. Project-related research has reconstructed the occupational history on an entire city block, offered alternative solutions to several knotty historicall problems, and provided a data base of artifacts and documents which will continue to assist future investigations into the life and times of nineteenth century San Antonio. 


\section{REFERENCES CITED}

Anonymous

n.d. Structures in Urban Renewal \#5 (Extension Area). Copy of draft manuscript in possession of author.

Appler, J.A.

1892- General Directories of the City of San Antonio. San Antonio. 1909

Bel1, W., G. Hume and R. Williamson

1971

La Villita Historic District, National Register of Historic Places Inventory Nomination Form. On file, Texas Historical Commission, Austin.

Bexar County Courthouse Deed Records

Bexar County District Court Records

Barber, E. A.

1904 Marks of American Potters. Patterson and White, Philadelphia.

Fox, A. A.

1977 The Archaeology and History of the Spanish Governor's Palace Park. Center for Archaeological Research. The University of Texas at San Antonio, Archaeological Survey Report 31.

Garner, J. C. (recorder)

1969 Architecture Survey, San Antonio, Bexar County. Historic American Buildings Survey Inventory.

Godden, G. A.

1964 Encyclopedia of British Pottery and Porcelain Marks. Bonanza Books, New York.

Johnson and Chapman, publishers

1891 General Directory of the City of San Antonio for the Year 1891. San Antonio.

Koch, A.

1873 Bird's Eye View of the City of San Antonio.

1886 Bird's Eye View of the City of San Antonio. 
Luckett, B.

n.d. Report of the Impossibility of the Stable Remains in NCB 155, Lot 26, Being Originally a Spanish Fort. Manuscript on file, Office of the State Archeologist, Texas Historical Commission, Austin.

MacMillan, E. G.

1971 High-Light History of the South Side of Arciniega Street from South Presa on the West to South Alamo on the East. Manuscript on file, San Antonio Conservation Society Library, San Antonio.

Microfilm

City Engineers Office, NCB 901.

Mooney and Morrison (publishers)

1877 General Directory of the City of San Antonio for 1877-78. Galveston.

Morrison and Fourmy (publishers)

1879- General Directories of the City of San Antonio. Galveston. 1889

Polk, R. L. and Co. (publishers)

1884 Texas State Gazetteer and Business Directory, 1884-5: Volume II. St. Louis.

Sanborn Insurance Company

1904 Maps of San Antonio, Volume I. New York.

1924 Maps of San Antonio, Volume III. New York.

Santos, R. G.

1967 The Quartel de San Antonio de Bexar. Texana 5(3):187-203.

Schuetz, M. K.

n.d. Archaeology of the Quartel. Manuscript on file, Office of the State Archeologist, Texas Historical Commission, Austin.

Smith. J. D.

n.d. John W. Smith Papers. Daughters of the Republic of Texas Library. 
Spanish Deed Records

Vol. 2:111-113.

Texas Publishing Company

1910 Directory of the City of San Antonio, 1910-1911. San Antonio. Woolford, S. (editor)

1963 San Antonio, A History for Tomorrow. Naylor, San Antonio. 


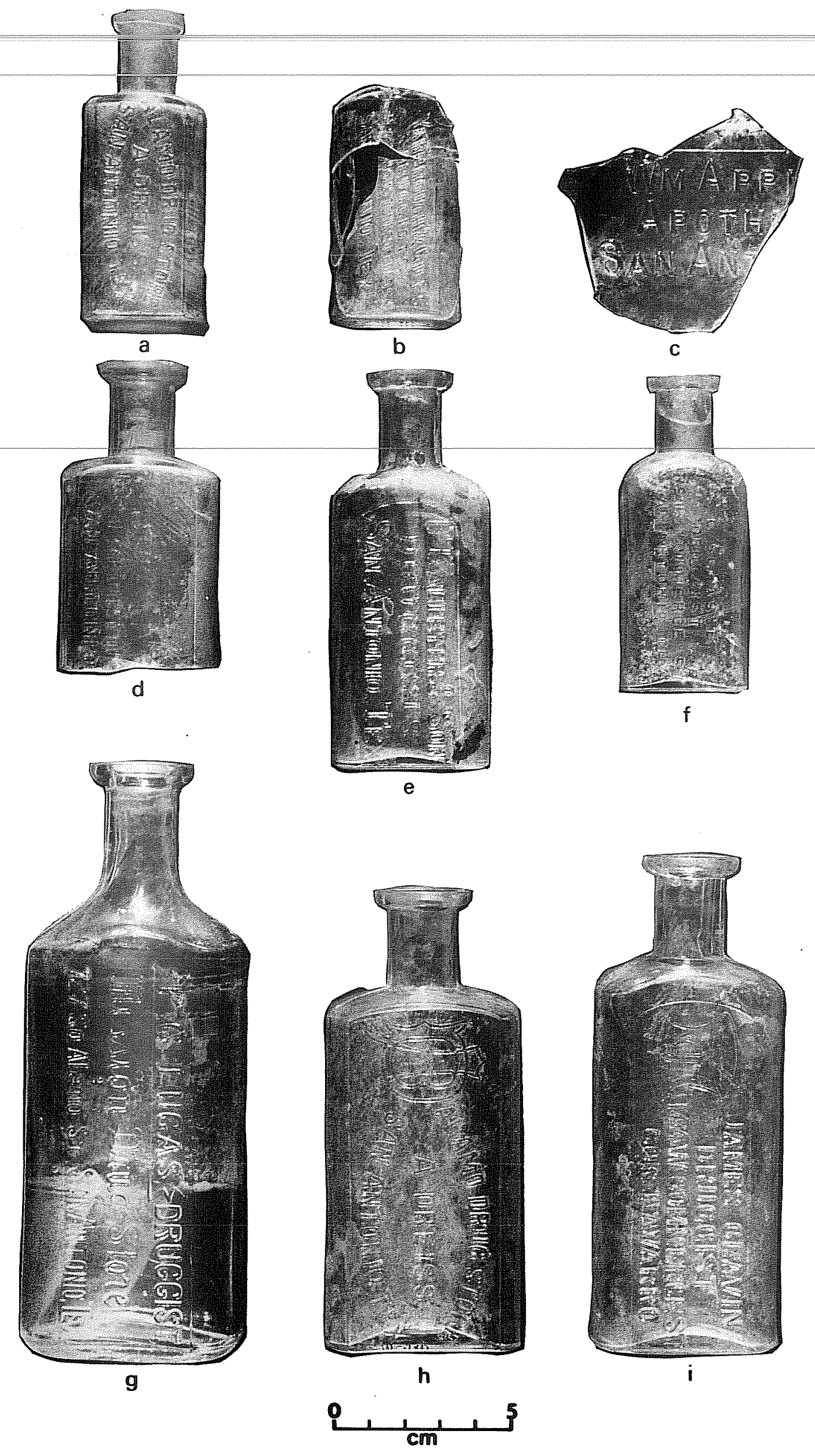



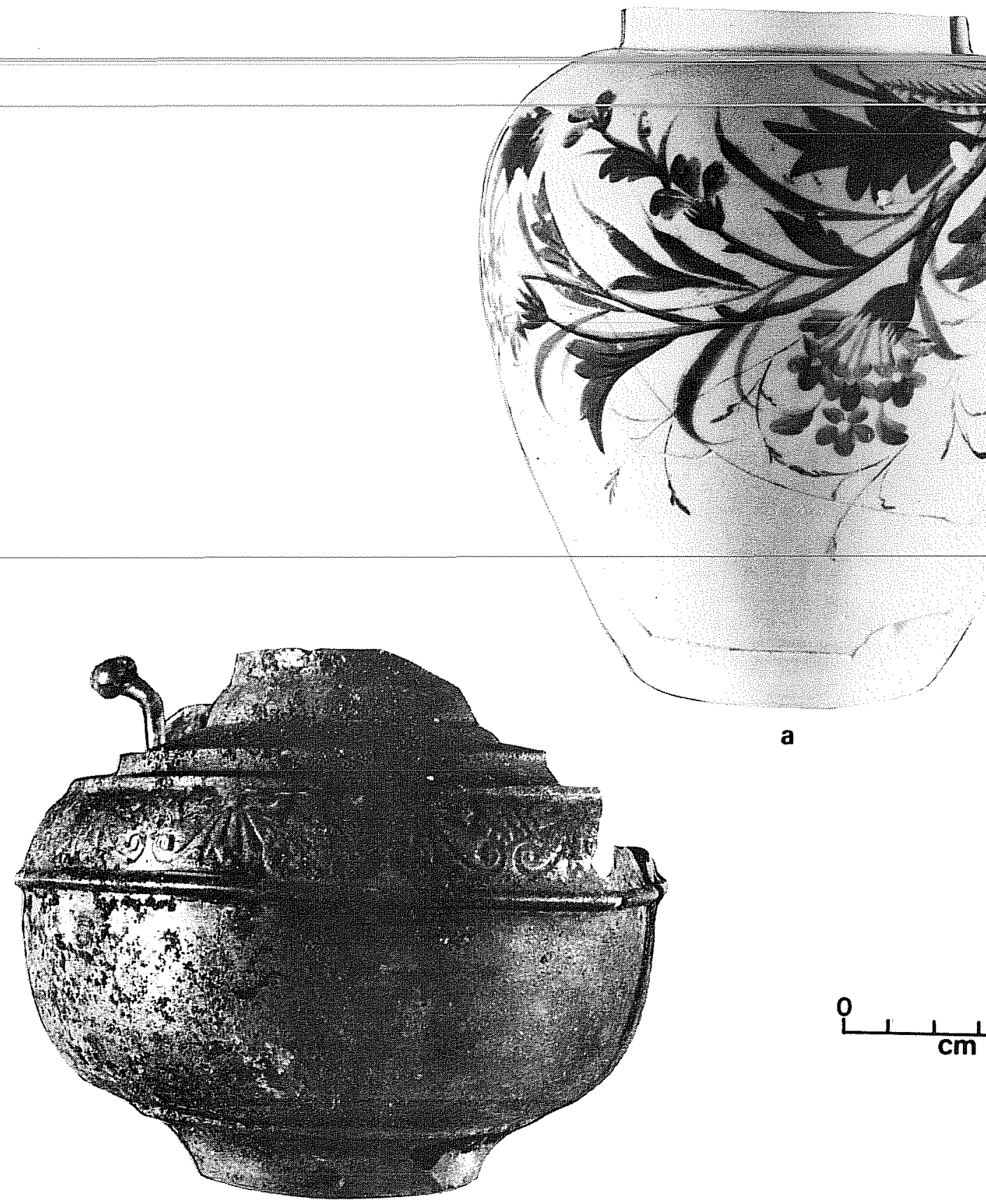

\section{,}




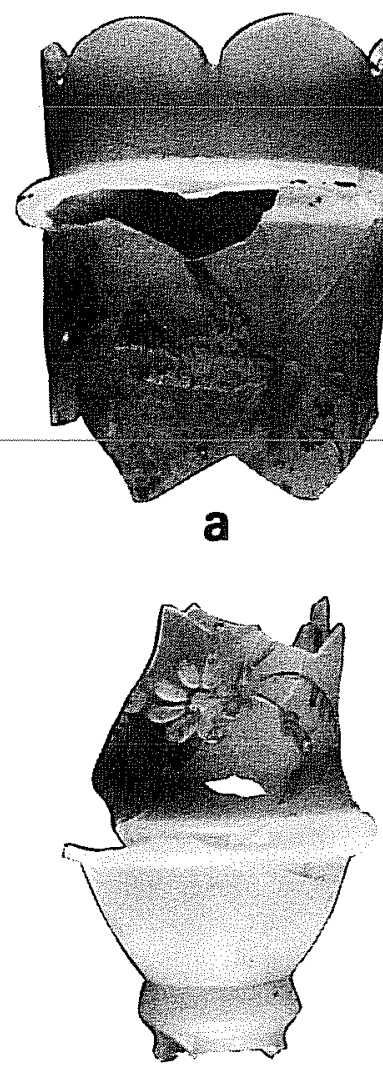

b

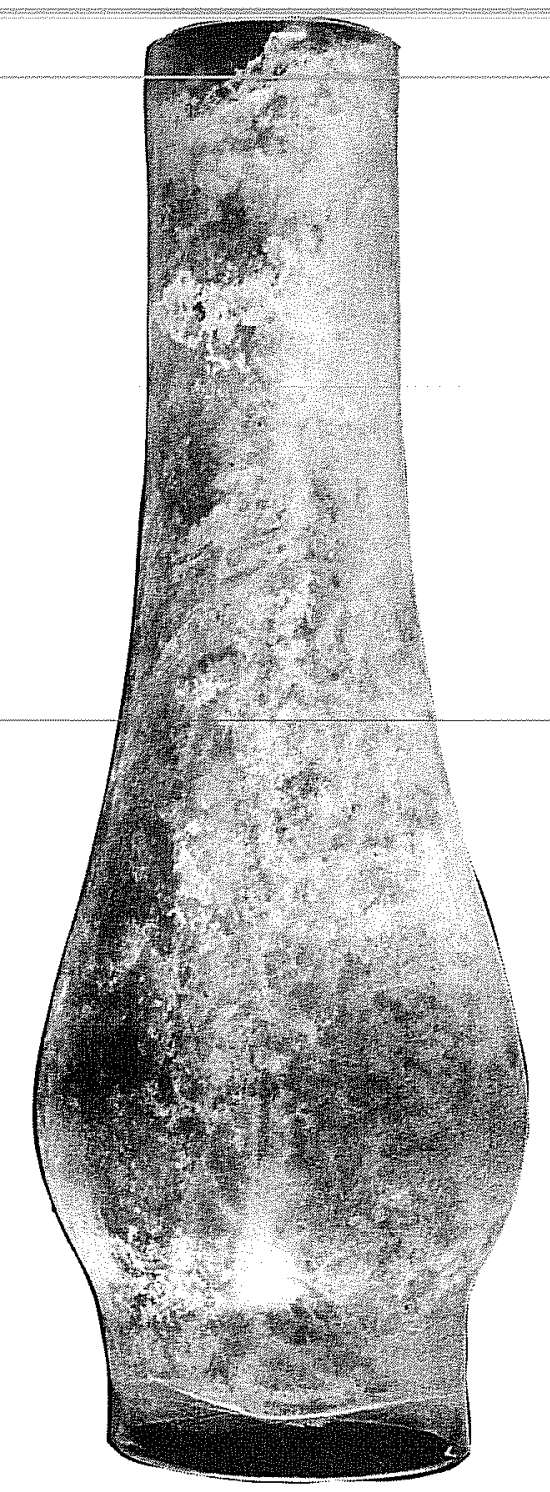

C

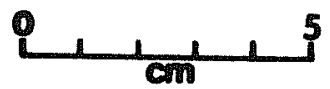

Figure 33. Selected Artifacts from Features 4 and $4 w:$ Lighting Fixtures. $a, b$, frosted glass with gold and white painted design; c, clear glass lamp chimney. 
